\title{
\#USGS
}

science for a changing world

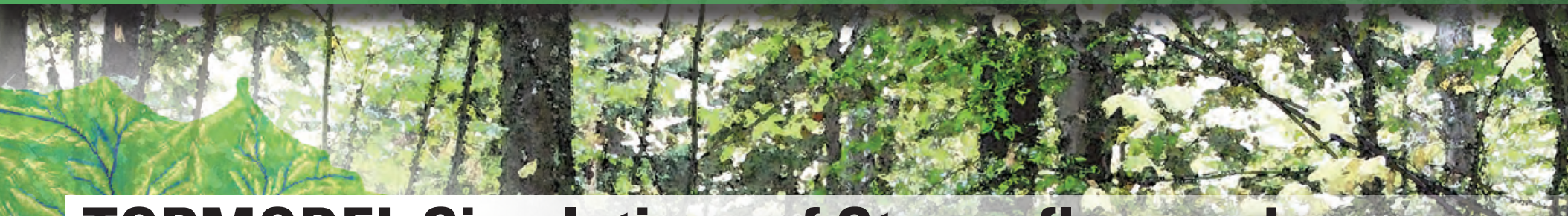

TOPMODEL Simulations of Streamflow and Depth to Water Table in Fishing Brook Watershed, New York, 2007-09

National Water-Quality Assessment Program

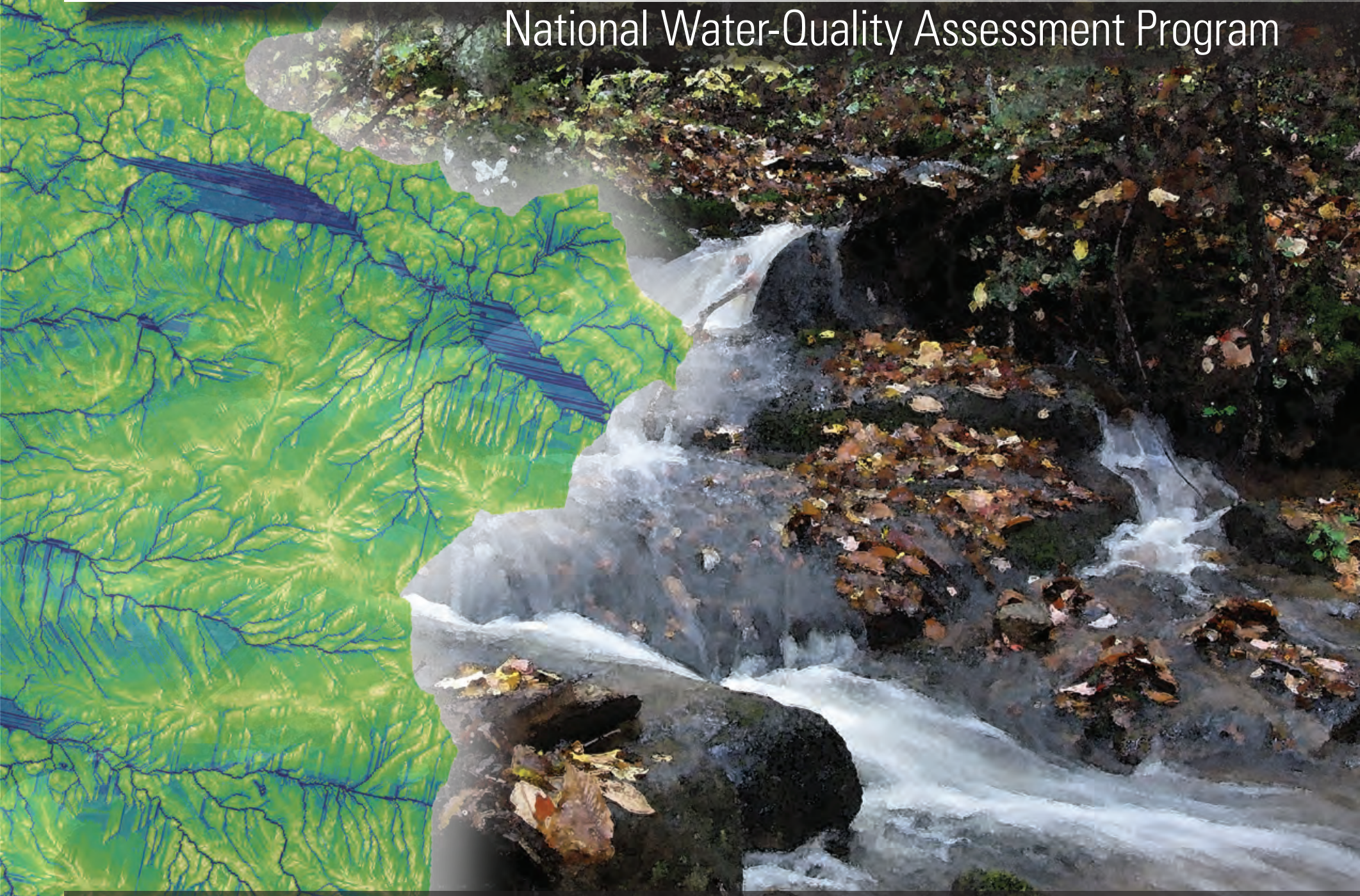

Scientific Investigations Report 2011-5190

U.S. Department of the Interior

U.S. Geological Survey

$+25$ 
Cover. Front cover: Inlet to Pickwacket Pond, taken 10/08/2009. Back cover: Sixmile Brook in Sixmile Wetland (with depth-to-water-table piezometers taken from site SS04, looking west towards sites SS05, MA08, and MA09), taken 05/19/2009. Both are in the Fishing Brook Watershed, near Long Lake, New York. Overlay image: Map of topographic wetness index. 
National Water-Quality Assessment Program

\section{TOPMODEL Simulations of Streamflow and Depth to Water Table in Fishing Brook Watershed, New York, 2007-09}

By Elizabeth A. Nystrom and Douglas A. Burns

Scientific Investigations Report 2011-5190 


\title{
U.S. Department of the Interior \\ KEN SALAZAR, Secretary \\ U.S. Geological Survey \\ Marcia K. McNutt, Director
}

\author{
U.S. Geological Survey, Reston, Virginia: 2011
}

For more information on the USGS - the Federal source for science about the Earth, its natural and living resources, natural hazards, and the environment, visit http://www.usgs.gov or call 1-888-ASK-USGS.

For an overview of USGS information products, including maps, imagery, and publications, visit http://www.usgs.gov/pubprod

To order this and other USGS information products, visit http://store.usgs.gov

Any use of trade, product, or firm names is for descriptive purposes only and does not imply endorsement by the U.S. Government.

Although this report is in the public domain, permission must be secured from the individual copyright owners to reproduce any copyrighted materials contained within this report.

Suggested citation:

Nystrom, E.A., and Burns, D.A., 2011, TOPMODEL simulations of streamflow and depth to water table in Fishing Brook Watershed, New York, 2007-09: U.S. Geological Survey Scientific Investigations Report 2011-5190, 54 p. at http://pubs.usgs.gov/sir/2011/5190/. 


\section{Foreword}

The U.S. Geological Survey (USGS) is committed to providing the Nation with reliable scientific information that helps to enhance and protect the overall quality of life and that facilitates effective management of water, biological, energy, and mineral resources (http://www.usgs. gov//). Information on the Nation's water resources is critical to ensuring long-term availability of water that is safe for drinking and recreation and is suitable for industry, irrigation, and fish and wildlife. Population growth and increasing demands for water make the availability of that water, measured in terms of quantity and quality, even more essential to the long-term sustainability of our communities and ecosystems.

The USGS implemented the National Water-Quality Assessment (NAWQA) Program in 1991 to support national, regional, State, and local information needs and decisions related to water-quality management and policy (http://water.usgs.gov/nawqa). The NAWQA Program is designed to answer: What is the quality of our Nation's streams and groundwater? How are conditions changing over time? How do natural features and human activities affect the quality of streams and groundwater, and where are those effects most pronounced? By combining information on water chemistry, physical characteristics, stream habitat, and aquatic life, the NAWQA Program aims to provide science-based insights for current and emerging water issues and priorities. From 1991 to 2001, the NAWQA Program completed interdisciplinary assessments and established a baseline understanding of water-quality conditions in 51 of the Nation's river basins and aquifers, referred to as Study Units (http://water.usgs.gov/nawqa/ studies/study_units.html).

In the second decade of the Program (2001-2012), a major focus is on regional assessments of water-quality conditions and trends. These regional assessments are based on major river basins and principal aquifers, which encompass larger regions of the country than the Study Units. Regional assessments extend the findings in the Study Units by filling critical gaps in characterizing the quality of surface water and groundwater, and by determining water-quality status and trends at sites that have been consistently monitored for more than a decade. In addition, the regional assessments continue to build an understanding of how natural features and human activities affect water quality. Many of the regional assessments employ modeling and other scientific tools, developed on the basis of data collected at individual sites, to help extend knowledge of water quality to unmonitored, yet comparable areas within the regions. The models thereby enhance the value of our existing data and our understanding of the hydrologic system. In addition, the models are useful in evaluating various resourcemanagement scenarios and in predicting how our actions, such as reducing or managing nonpoint and point sources of contamination, land conversion, and altering flow and (or) pumping regimes, are likely to affect water conditions within a region.

Other activities planned during the second decade include continuing national syntheses of information on pesticides, volatile organic compounds (VOCs), nutrients, trace elements, and aquatic ecology; and continuing national topical studies on the fate of agricultural chemicals, effects of urbanization on stream ecosystems, bioaccumulation of mercury in stream ecosystems, effects of nutrient enrichment on stream ecosystems, and transport of contaminants to public-supply wells. 
The USGS aims to disseminate credible, timely, and relevant science information to address practical and effective water-resource management and strategies that protect and restore water quality. We hope this NAWQA publication will provide you with insights and information to meet your needs, and will foster increased citizen awareness and involvement in the protection and restoration of our Nation's waters.

The USGS recognizes that a national assessment by a single program cannot address all water-resource issues of interest. External coordination at all levels is critical for cost-effective management, regulation, and conservation of our Nation's water resources. The NAWQA Program, therefore, depends on advice and information from other agencies-Federal, State, regional, interstate, Tribal, and local-as well as nongovernmental organizations, industry, academia, and other stakeholder groups. Your assistance and suggestions are greatly appreciated.

William H. Werkheiser

USGS Associate Director for Water 


\section{Acknowledgments}

The authors wish to thank the staff at the Adirondack Ecological Center of the State University of New York, College of Environmental Science and Forestry (SUNY-ESF) for providing access to facilities and equipment at the Huntington Wildlife Forest. Special acknowledgment goes to Myron Mitchell from SUNY-ESF for access to meteorological and flow data from the Arbutus Lake Watershed. The authors would like to thank Finch, Pruyn \& Co. and The Nature Conservancy for providing access to the Fishing Brook Watershed. 
This page has been left blank intentionally. 


\section{Contents}

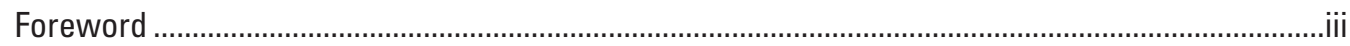

Acknowledgments

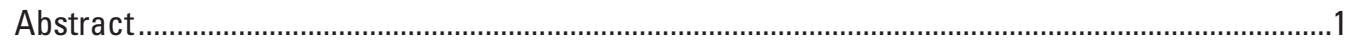

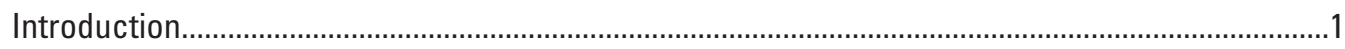

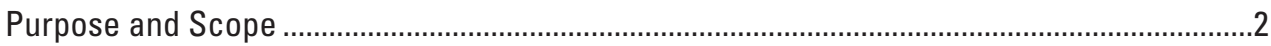

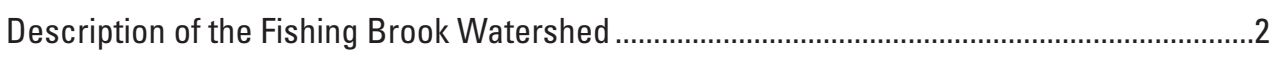

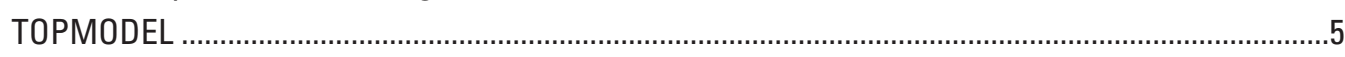

Topographic Wetness Index and Saturation Deficit................................................................

TOPMODEL Streamflow-Generation Concepts ......................................................................

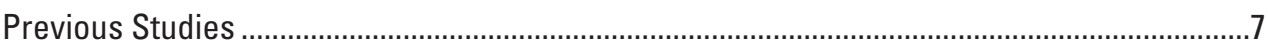

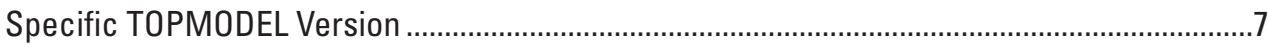

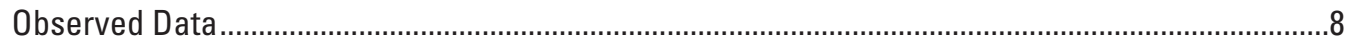

Input Data for Model Processing .....................................................................................

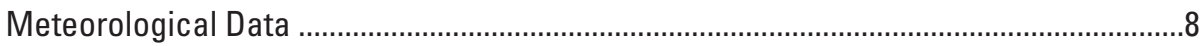

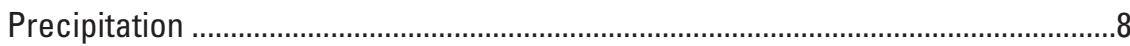

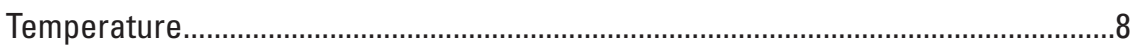

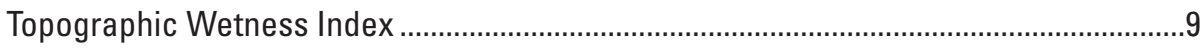

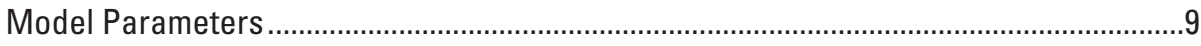

Watershed Characteristics .................................................................................

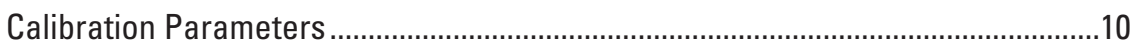

Unused Model Parameters .....................................................................................11

Observed Streamflow and Depth to Water Table for Model Evaluation ..................................11

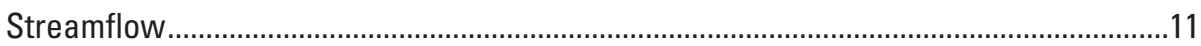

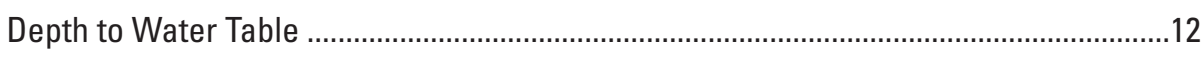

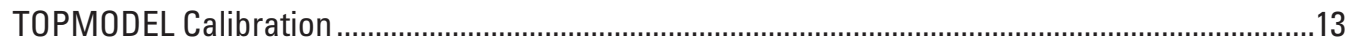

Snowmelt Calibration .....................................................................................................

Results of Snowmelt Calibration ...........................................................................

Runoff and Depth-to-Water-Table Calibration .....................................................................19

Runoff Objective Function .....................................................................................19

Depth-to-Water-Table Objective Functions.................................................................20

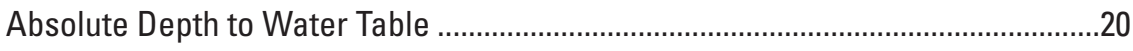

Relative Depth-to-Water-Table Fluctuations........................................................20

Combined Multiple-Objective Function.......................................................................

Generalized Sensitivity Analysis .......................................................................................2

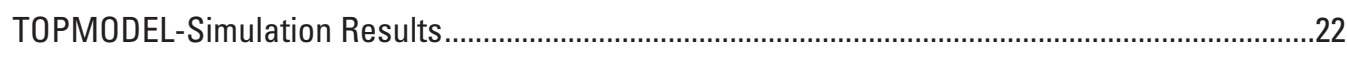

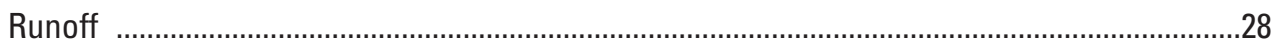

Prediction-Interval Uncertainty Analysis .....................................................................

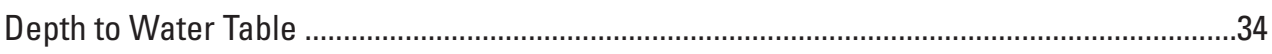

Prediction-Interval Uncertainty Analysis ....................................................................42

Application of Calibration to Subwatersheds .....................................................................4

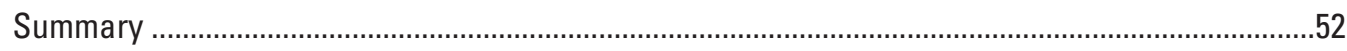

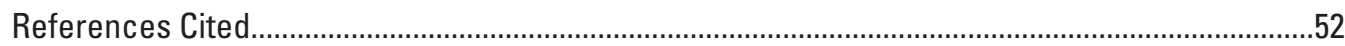




\section{Figures}

1. Map showing location and principal hydrologic features of the Fishing Brook study area, New York.

2. Map showing topography of the Fishing Brook study area, New York, and subwatersheds, model-assessment points, and synoptic sites.

3. Map showing topographic wetness index and wetland areas in the Fishing Brook study area, New York

4. Graph showing relative frequency distribution of the topographic wetness index for the Fishing Brook study area, New York

5. Graph showing monthly mean runoff at U.S. Geological Survey streamgages 01312000, Hudson River near Newcomb, New York, and 0131199050, Fishing Brook at County Line Flow near Newcomb, New York

6. Photograph showing Sixmile Wetland with depth-to-water-table piezometers, May 2009. Photograph taken from site SS04, looking west towards sites SS05, MA08, and MA09

7. Graph showing observed depth to water table at Sixmile Wetland, Fishing Brook study area, New York, May and August 2009

8. Graph showing observed depth-to-water-table fluctuations at Sixmile Wetland, Fishing Brook study area, New York, April-August 2009

9. Graphs showing snowmelt calibration $A$, raw precipitation and temperature, $B$, equivalent liquid precipitation and simulated snow water-equivalent depth, and $C$, simulated and observed runoff for Fishing Brook at County Line Flow near Newcomb, New York, water year 2007.

10. Graphs showing snowmelt calibration $A$, raw precipitation and temperature, $B$, equivalent liquid precipitation and simulated snow water-equivalent depth, and $\mathrm{C}$, simulated and observed runoff for Fishing Brook at County Line Flow near Newcomb, New York, water year 2008

11. Graphs showing snowmelt calibration $A$, raw precipitation and temperature, $B$, equivalent liquid precipitation and simulated snow water-equivalent depth, and $C$, simulated and observed runoff for Fishing Brook at County Line Flow near Newcomb, New York, water year 2009

12. Graphs showing Nash-Sutcliffe efficiency of runoff for snowmelt calibration-parameter space for A, water year (WY) 2007, B, WY 2008, and C, WY 2009 .

13. Graphs showing generalized sensitivity analysis cumulative-probability distributions for TOPMODEL calibration parameters with Kolmogorov-Smirnov $d$ statistic value

14. Dotty plots of combined multiple-objective function and component-objective functions.

15. Graphs showing simulated runoff and watershed-average saturation deficit, best run for the modeling period and prediction intervals, Fishing Brook at County Line Flow near Newcomb, New York, water year 2007

16. Graphs showing simulated runoff and watershed-average saturation deficit, best run for the modeling period and prediction intervals, Fishing Brook at County Line Flow near Newcomb, New York, water year 2008.

17. Graphs showing simulated runoff and watershed-average saturation deficit, best run for the modeling period and prediction intervals, Fishing Brook at County Line Flow near Newcomb, New York, water year 2009. 
18. Boxplots of calibration-parameter values, by prediction-interval class

19. Graph showing simulated runoff, observed runoff, and equivalent liquid precipitation for Fishing Brook at County Line Flow near Newcomb, New York, best run for the modeling period.

20. Graphs showing simulated runoff, observed runoff, residuals, and equivalent liquid precipitation for Fishing Brook at County Line Flow near Newcomb, New York, best run for the modeling period for A, water year (WY) 2007, B, WY 2008, and C, WY 2009.

21. Scatter plot of observed runoff and simulated runoff for Fishing Brook at County Line Flow near Newcomb, New York, best run for the modeling period.

22. Scatter plot of simulated runoff and residuals for Fishing Brook at County Line Flow near Newcomb, New York, best run for the modeling period

23. Graph showing flow-duration curves of observed and simulated runoff for Fishing Brook at County Line Flow near Newcomb, New York, best run for the modeling period

24. Graphs showing A, Cumulative simulated and observed runoff, and B, cumulative difference, simulated and observed runoff, for Fishing Brook at County Line Flow near Newcomb, New York, best run and range for all model runs for the modeling period

25. Boxplots of simulated runoff for A, low flow (September 5, 2007), B, moderate flow (May 5, 2009), and C, high flow (April 24, 2007) example days, Fishing Brook at County Line Flow near Newcomb, New York, by prediction-interval class.

26. Diagram showing width of runoff prediction intervals for the modeling period for Fishing Brook at County Line Flow near Newcomb, New York, by predictioninterval class

27. Graphs showing simulated depth to water table at Sixmile Wetland, Fishing Brook study area, New York, best run for the modeling period and prediction intervals for A, water year (WY) 2007, B, WY 2008, and C, WY 2009.

28. Graph showing simulated and observed depth to water table at Sixmile Wetland, Fishing Brook study area, New York, best run for the modeling period and prediction intervals, April-August 2009.

29. Graph showing simulated and observed relative depth-to-water-table fluctuations at Sixmile Wetland, Fishing Brook study area, New York, best run for the modeling period and prediction intervals, April-August 2009

30. Scatter plot of observed and simulated depth above average at Sixmile Wetland, Fishing Brook study area, New York, April-August 2009, best run for the modeling period

31. Graph showing simulated saturation deficit and depth to water table, Fishing Brook study area average, Sixmile Wetland, and example upland area, best run for the modeling period.

32. Graph showing simulated saturated area, as percent of Fishing Brook study area, New York, best run for the modeling period.

33. Map showing simulated saturated areas, showing minimum and maximum saturation of Fishing Brook study area, New York, best run for the modeling period ....43

34. Boxplots of simulated watershed-average saturation deficit for $A$, low flow (September 5, 2007), B, moderate flow (May 5, 2009), and C, high flow (April 24, 2007) example days, Fishing Brook study area, New York, by predictioninterval class 
35. Diagram showing width of simulated watershed-average saturation deficit prediction intervals for the modeling period, Fishing Brook study area, New York, by prediction-interval class

36. Boxplots of simulated depth to water table at Sixmile Wetland, Fishing Brook study area, New York, for A, low flow (September 5, 2007), B, moderate flow (May 5, 2009), and C, high flow (April 24, 2007) example days, by prediction-interval class........46

37. Diagram showing width of simulated depth-to-water-table prediction intervals for the modeling period, Fishing Brook study area, New York, by predictioninterval class

38. Graphs showing simulated runoff for selected subwatersheds, Fishing Brook study area, New York, for A, water year (WY) 2007, B, WY 2008, and C, WY 2009.

39. Graphs showing simulated saturation deficit and watershed-average depth to water table for selected subwatersheds for A, water year (WY) 2007, B, WY 2008, and C, WY 2009

40. Scatter plot of simulated runoff and observed runoff for selected subwatersheds, Fishing Brook study area, New York

\section{Tables}

1. TOPMODEL calibration parameters, watershed characteristics, and data sources

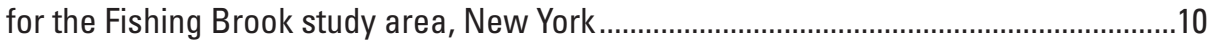

2. Snowmelt calibration-parameter ranges and fixed values ..............................................15

3. Snowmelt calibration parameter and objective values, by water year ...........................15

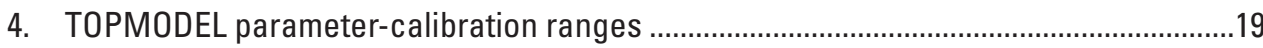

5. Calibrated-model parameter values, best run, and prediction-interval classes ..............26

6. Objective-function values for selected model runs and ranges .....................................28

7. Descriptive statistics for simulated runoff, best run, and all model runs during the model period for Fishing Brook at County Line Flow near Newcomb, New York

8. Descriptive statistics for observed and simulated daily mean runoff and best run during the model period for Fishing Brook at County Line Flow near Newcomb, New York

9. Runoff prediction-interval widths, by class, for Fishing Brook at County Line Flow near Newcomb, New York

10. Descriptive statistics for simulated saturation deficit and depth to water table for the best run during the model period for Fishing Brook study area average, Sixmile Wetland, and example upland area.

11. Simulated depth-to-water-table goodness-of-fit statistics for the best run and all model runs

12. Saturation-deficit prediction-interval widths, by prediction-interval class . . .44

13. Depth to water table in Sixmile Wetland prediction-interval widths, by prediction-interval class.

14. Subwatershed characteristics for the Fishing Brook study area ..

15. Streamflow measurements at synoptic survey sites for the Fishing Brook study area, New York, 2007-09. 


\section{Conversion Factors and Datum}

\begin{tabular}{lcl}
\hline Multiply & By & To obtain \\
\hline centimeter $(\mathrm{cm})$ & Length & \\
millimeter $(\mathrm{mm})$ & 0.3937 & inch (in.) \\
meter $(\mathrm{m})$ & 0.03937 & inch (in.) \\
kilometer $(\mathrm{km})$ & 3.281 & foot (ft) \\
\hline & 0.6214 & mile (mi) \\
\hline square kilometer $\left(\mathrm{km}^{2}\right)$ & Area & acre \\
square kilometer $\left(\mathrm{km}^{2}\right)$ & 247.1 & square mile $\left(\mathrm{mi}{ }^{2}\right)$ \\
\hline & 0.3861 & \\
\hline millimeter per day $(\mathrm{mm} / \mathrm{d})$ & Flow rate & inch per day (in/d) \\
\hline
\end{tabular}

Temperature in degrees Celsius $\left({ }^{\circ} \mathrm{C}\right)$ may be converted to degrees Fahrenheit $\left({ }^{\circ} \mathrm{F}\right)$ as follows:

${ }^{\circ} \mathrm{F}=\left(1.8 x^{\circ} \mathrm{C}\right)+32$

Vertical coordinate information is referenced to the North American Vertical Datum of 1988 (NAVD 88)

Horizontal coordinate information is referenced to the North American Datum of 1983 (NAD 83)

Elevation, as used in this report, refers to distance above the vertical datum.

Water year: The 12-month period from 0ctober 1 through September 30. The water year is designated by the calendar year in which it ends. 


\section{Acronyms and Abbreviations}

\begin{tabular}{|c|c|}
\hline CASTNET & Clean Air Status and Trends Network \\
\hline$c d f$ & cumulative-distribution function \\
\hline DEM & digital elevation model \\
\hline DOC & dissolved organic carbon \\
\hline$E$ & Nash-Sutcliffe coefficient of model-fit efficiency \\
\hline$E(\ln )$ & Nash-Sutcliffe coefficient evaluated for the natural logarithm of a quantity \\
\hline ESRI & Environmental Systems Resource Institute \\
\hline GBMM & grid-based mercury model \\
\hline GLUE & Generalized Likelihood Uncertainty Estimate \\
\hline $\mathrm{Hg}$ & mercury \\
\hline KSD & Kolmogorov-Smirnov $d$ \\
\hline MA01-MA13 & model-assessment points 01 to 13 \\
\hline MAE & mean absolute error \\
\hline NADP & National Atmospheric Deposition Program \\
\hline NADP-NTN & National Atmospheric Deposition Program-National Trends Network \\
\hline NAWQA & National Water-Quality Assessment Program \\
\hline NED & National Elevation Dataset \\
\hline NHD & National Hydrography Dataset \\
\hline$r$ & Pearson's correlation coefficient \\
\hline RMSE & root mean squared error \\
\hline$S$ & saturation deficit \\
\hline SS01-07 & synoptic sites 01 to 07 \\
\hline SSURGO & Soil Survey Geographic Database \\
\hline SUNY-ESF & State University of New York College of Environmental Science and Forestry \\
\hline TWI & topographic wetness index \\
\hline USGS & U.S. Geological Survey \\
\hline WATER & Water Availability Tool for Environmental Resources \\
\hline WY & water year \\
\hline
\end{tabular}




\title{
TOPMODEL Simulations of Streamflow and Depth to Water Table in Fishing Brook Watershed, New York, 2007-09
}

\author{
By Elizabeth A. Nystrom and Douglas A. Burns
}

\section{Abstract}

TOPMODEL, a physically based, variable-source area rainfall-runoff model, was used to simulate streamflow and depth to water table for the period January 2007-September 2009 in the 65.6 square kilometers of Fishing Brook Watershed in northern New York. The Fishing Brook Watershed is located in the headwaters of the Hudson River and is predominantly forested with a humid, cool continental climate. The motivation for applying this model at Fishing Brook was to provide a simulation that would be effective later at this site in modeling the interaction of hydrologic processes with mercury dynamics.

TOPMODEL uses a topographic wetness index computed from surface-elevation data to simulate streamflow and subsurface-saturation state, represented by the saturation deficit. Depth to water table was computed from simulated saturation-deficit values using computed soil properties. In the Fishing Brook Watershed, TOPMODEL was calibrated to the natural logarithm of streamflow at the study area outlet and depth to water table at Sixmile Wetland using a combined multiple-objective function. Runoff and depth to water table responded differently to some of the model parameters, and the combined multiple-objective function balanced the goodness-of-fit of the model realizations with respect to these parameters. Results show that TOPMODEL reasonably simulated runoff and depth to water table during the study period. The simulated runoff had a Nash-Sutcliffe efficiency of 0.738 , but the model underpredicted total runoff by 14 percent. Depth to water table computed from simulated saturation-deficit values matched observed water-table depth moderately well; the root mean squared error of absolute depth to water table was 91 millimeters $(\mathrm{mm})$, compared to the mean observed depth to water table of $205 \mathrm{~mm}$. The correlation coefficient for temporal depth-to-water-table fluctuations was 0.624 . The variability of the TOPMODEL simulations was assessed using prediction intervals grouped using the combined multiple-objective function. The calibrated TOPMODEL results for the entire study area were applied to several subwatersheds within the study area using computed hydrogeomorphic properties of the subwatersheds.

\section{Introduction}

Mercury $(\mathrm{Hg})$ is a potent neurotoxin that originates as emissions largely from human activities such as coal-fueled power generation and to a lesser extent from natural sources such as volcanism (Selin, 2009). These $\mathrm{Hg}$ emissions are transported by and later deposited from the atmosphere at local, regional, and global scales where many hydrological, geochemical, and biological processes affect the movement and accumulation of $\mathrm{Hg}$ in biota that can include humans through fish consumption. Identifying and modeling the processes that control $\mathrm{Hg}$ cycling in the environment is an important research goal and presents a formidable multidisciplinary challenge. One key element in this challenge is identifying and modeling the role of hydrological processes in transporting $\mathrm{Hg}$ from soils, where large stores representing decades of $\mathrm{Hg}$ deposition are present (Munthe and others, 2007), to the aquatic environment, where bioaccumulation and food web dynamics can result in $\mathrm{Hg}$ levels in freshwater fish that are considered unsafe for human consumption. Elevated levels of $\mathrm{Hg}$ in fish are a widespread problem, with fishconsumption advisories issued by all 50 States in the United States (U.S. Environmental Protection Agency, 2009).

The U.S. Geological Survey (USGS) National WaterQuality Assessment Program (NAWQA) includes studies to better understand the processes that control the cycling of $\mathrm{Hg}$ as it affects rivers and streams in the U.S. An objective of the current (2011) NAWQA Hg study, of which this report represents a component, is testing and developing models that will lead to improved understanding of how watershed hydrological processes are linked to $\mathrm{Hg}$ bioaccumulation. Factors such as hydrological flow paths, watershed geomorphology, the permeability of soils, and many others may affect processes such as transport and methylation, which greatly influence $\mathrm{Hg}$ bioaccumulation. Past $\mathrm{Hg}$-modeling approaches focused explicitly on biogeochemical and physical processes within lakes (Driscoll and others, 1995) and sometimes with inclusion of a simple watershed-loading factor (Knightes and Ambrose, 2007). Other Hg-modeling studies have linked the terrestrial environment with surface waters by applying simple catchment-transfer factors (Knightes, 2008) 
with some capable of moving Hg among vegetation, soils, groundwater, and the stream or lake (Chen and others, 2008; Chen and Herr, 2010). Despite an often detailed representation of the biogeochemical and physical processes that control $\mathrm{Hg}$ transformations in many of these models, most do not consider spatial representations of catchment hydrology, which may greatly affect $\mathrm{Hg}$ dynamics and transport such as a distinction between riparian and upland areas (Chen and others, 2008; Knightes, 2008).

A goal of the current (2011) NAWQA study is to develop improved modeling approaches that link hydrological processes to $\mathrm{Hg}$ transport in riverine settings. TOPMODEL, a semi-distributed, variable-source, physically based rainfallrunoff model was selected as an appropriate model for application in this case because the model is believed to provide a good representation of hydrologic-flow sources to streams (Hornberger and others, 1994), and Hg mobility has been shown to be strongly linked with these surface- and shallow subsurface-flow processes (Krabbenhoft and others, 1995; Schelker and others, 2011). In particular, the ability of TOPMODEL to simulate the depth of the water table on a daily basis as a function of the topographic wetness index (TWI) (a computed value that describes the likelihood of saturation, described later in text) provides a potentially attractive approach to simulate $\mathrm{Hg}$ transport from shallow flow paths as a function of catchment geomorphological variation.

In this study, TOPMODEL was applied at the Fishing Brook Watershed, a headwater of the Upper Hudson River Basin in New York State, for the period January 2007-September 2009. TOPMODEL was calibrated to observed runoff and depth to water table in the Fishing Brook Watershed using a Monte Carlo calibration evaluated with a combined multiple-objective function. Calibration results for the watershed also were used to simulate runoff and depth to water table for subwatersheds within the study area. The results of this model are intended for use as input to several additional Hg-modeling efforts as part of the NAWQA Program Hg study. Model-generated simulations of daily streamflow, water-table depth, and water fluxes from various flow-generation processes are anticipated to prove useful in these Hg-modeling applications, which are currently (2011) in process.

\section{Purpose and Scope}

The purpose of this report is to document the methods and results of a hydrologic-model application to the Fishing Brook Watershed, N.Y. The semi-distributed hydrologic model, TOPMODEL, was used to simulate streamflow and watershed-average saturation deficit on a daily basis for Fishing Brook Watershed and subwatersheds during 2007-09. Data used for model input and evaluation included locally observed hydrologic and meteorologic data and remotely sensed digital elevation model (DEM) and soils data. TOPMODEL parameters were calibrated to observed streamflow and depth to water table using a multipleobjective Monte-Carlo optimization. A simplified predictioninterval uncertainty analysis was performed to assess the uncertainty and variability in the model results. Results from the Fishing Brook Watershed were applied to simulations in subwatersheds, which were compared to available discretestreamflow measurements.

The TOPMODEL code used in this modeling effort contains a combination of English and metric units. For consistency within this report, all values used were converted to metric units.

\section{Description of the Fishing Brook Watershed}

Fishing Brook is a tributary of the Hudson River near its headwaters in New York (fig. 1). The study area, which covers $65.6 \mathrm{~km}^{2}$, is defined as the portion of the Fishing Brook Watershed above USGS streamgage 0131199050, Fishing Brook at County Line Flow near Newcomb, N.Y. (fig. 1). The study area is located in Hamilton and Essex Counties in northern New York State and has a humid continental climate with cool summers. The mean yearly temperature is $4.4^{\circ} \mathrm{C}$, and the study area receives an average of $1,080 \mathrm{~mm}$ of precipitation per year (National Climatic Data Center, 2002). Precipitation is distributed fairly evenly throughout the year, without specific wet or dry seasons, but much of the precipitation for December-March is snowfall, and as a result, streamflow in the study area shows significant seasonal trends, with the greatest flows usually observed during the spring snowmelt. Elevations in the study area range from $502 \mathrm{~m}$ at the outlet of the study area to $1,083 \mathrm{~m}$; the highest elevations in the study area (over 1,000 m) are at the northern and southern ends of the basin (fig. 2).

The Fishing Brook study area is located in the Eastern Forest-Boreal Transition Ecoregion and is mostly (87 percent) forested with a mix of deciduous and evergreen forest; the remainder of land cover in the basin includes wetlands ( 9 percent), open water ( 3 percent), and developed land (1 percent) (Homer and others, 2004). Only one major paved road exists in the basin - route $28 \mathrm{~N}$ (fig. 1) - and less than 1 percent of the basin area consists of impervious surfaces. Very few structures exist in the watershed and there is little, if any, year-round human habitation. Surficial geology in the watershed reflects the effects of the Wisconsin glaciation; most of the watershed is covered in a thin layer of poorly sorted glacial till, with outwash and alluvial deposits of better-sorted material present in the valleys and low-lying areas of the watershed (Cadwell, 1991). The bedrock in the study area is mainly composed of granitic gneiss (Fisher and others, 1970).

The main tributary to Fishing Brook in the study area is Sixmile Brook; other tributaries in the basin generally are unnamed. Hydraulically well-connected riparian wetlands are present along streams throughout the basin, and the watershed contains a large wetland complex - the County Line Flow Swamp Megawetland (LaPoint and others, 2004) -a $2.8 \mathrm{~km}^{2}$ 


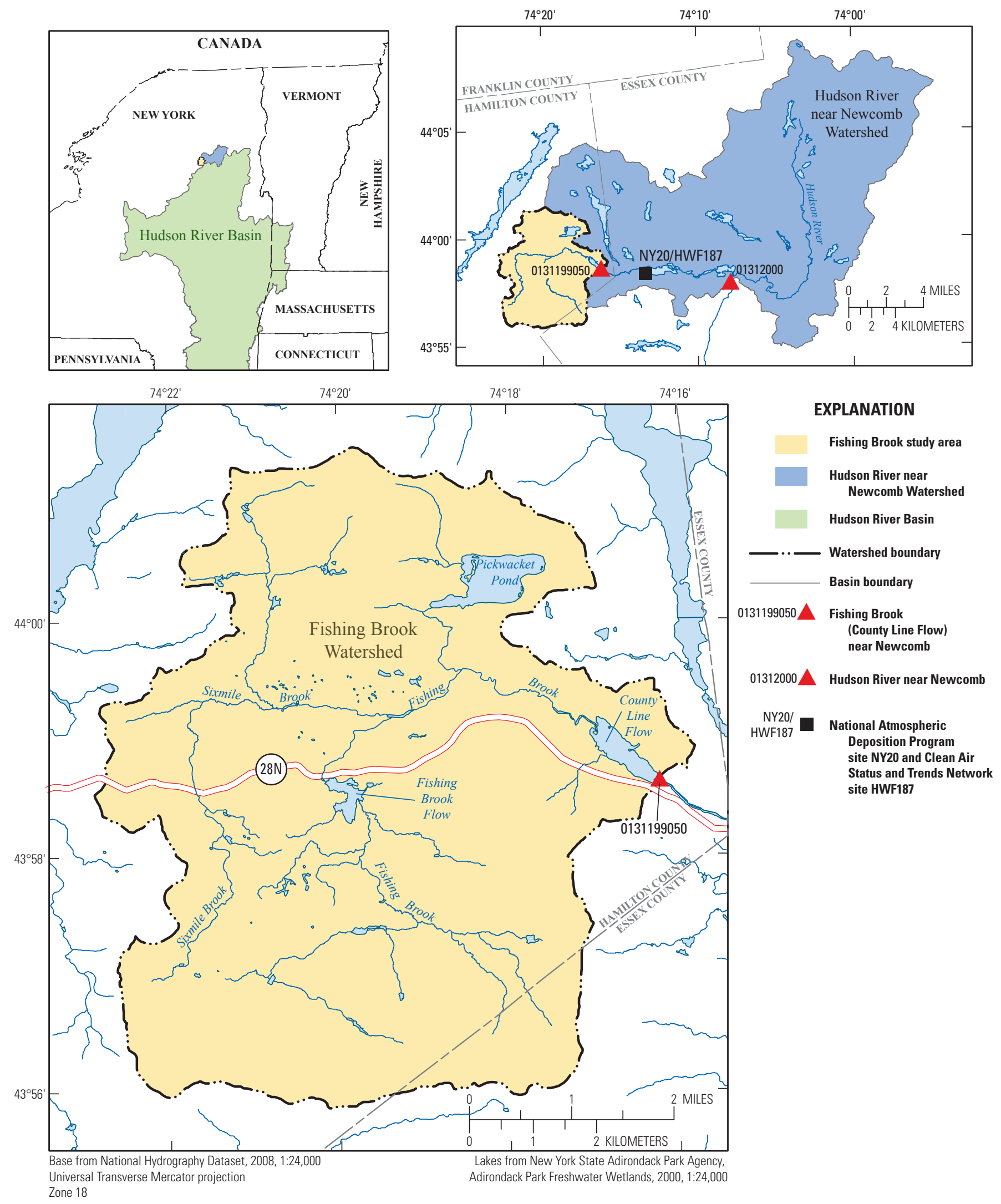

Figure 1. Location and principal hydrologic features of the Fishing Brook study area, New York. 

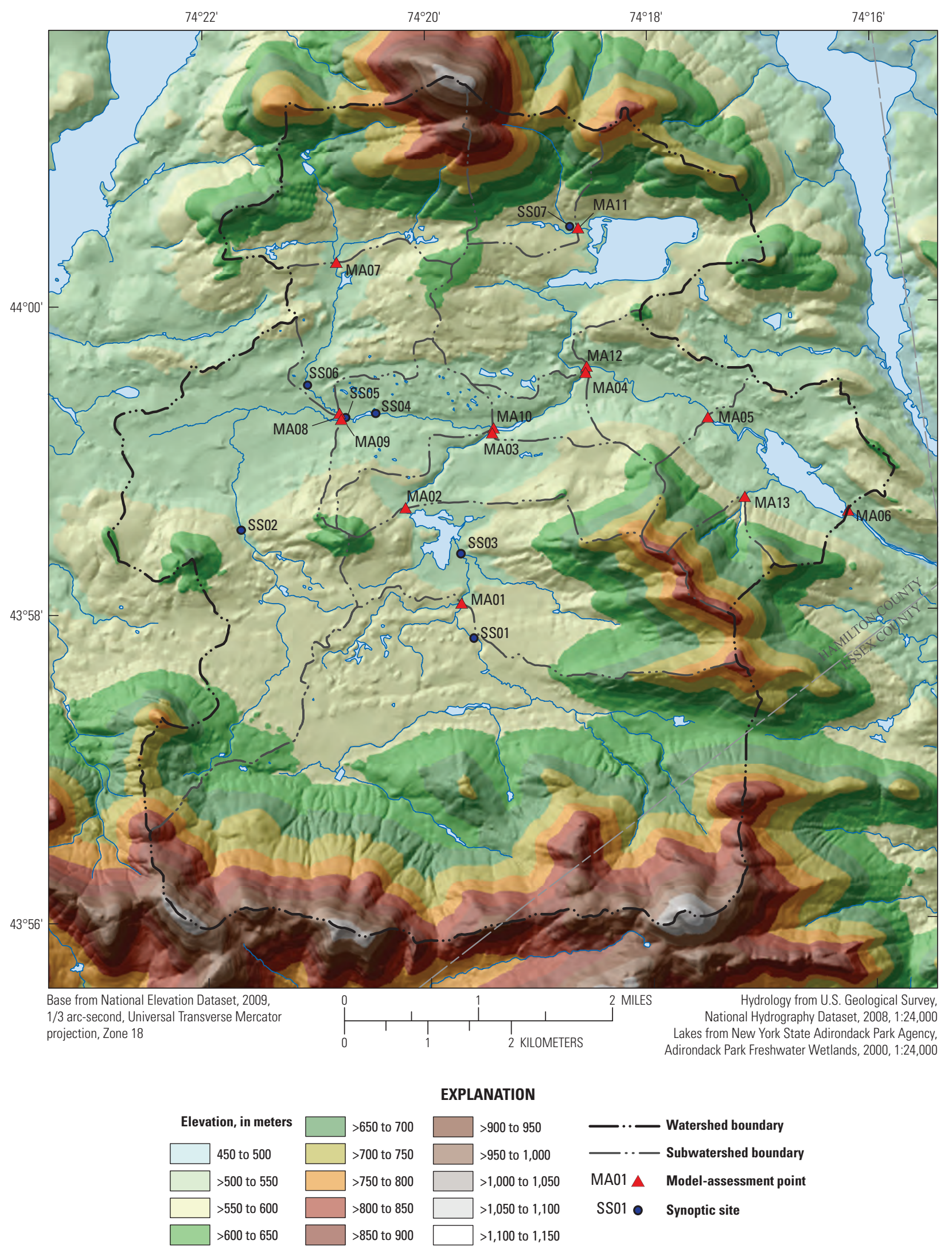

Figure 2. Topography of the Fishing Brook study area, New York, and subwatersheds, model-assessment points, and synoptic sites. 
riparian wetland consisting of scrub-shrub vegetation, coniferous forested swamp, and emergent marsh, of which Sixmile Wetland (approximately $1 \mathrm{~km}^{2}$ ) is a part (fig. 3). Major surface-water impoundments in the watershed include County Line Flow, $0.4 \mathrm{~km}^{2}$ surface area; Pickwacket Pond, $0.8 \mathrm{~km}^{2}$; and Fishing Brook Flow, $0.2 \mathrm{~km}^{2}$ (fig. 1).

\section{TOPMODEL}

TOPMODEL, first proposed by Beven and Kirkby (1979), is a physically based, semi-distributed, variable-source area rainfall-runoff model, and is based on the TWI proposed by Kirkby (1975). Three main assumptions underlie most formulations of TOPMODEL (Beven and others, 1995):

1. The hydraulic gradient of the water table can be approximated by the land-surface slope.

2. Dynamic conditions can be adequately represented by a steady-state approximation.

3. The saturated hydraulic conductivity decreases exponentially with depth.

TOPMODEL is expected to be best applied in watersheds where these assumptions hold, for example, humid watersheds with shallow soils, which are likely to have topographic controls on water-table depth (Beven and others, 1995). TOPMODEL groups areas of hydrological similarity using a topographically based wetness index and simulates runoff generation from several sources based on calculated watershed storage and storage deficits.

\section{Topographic Wetness Index and Saturation Deficit}

The TWI represents the local subsurface hydraulic conditions by combining the local hydraulic gradient (approximated by the local surface slope) and the volume of water draining through a point (proportionate to the upslope contributing area). The TWI is defined as

$$
T W I=\ln \left(\frac{\alpha}{\tan \beta}\right)
$$

where

$$
\begin{aligned}
& T W I \text { is the topographic wetness index, in } \\
& \ln (\text { meters); } \\
& \ln \text { is the natural logarithm; } \\
& \alpha \text { is the upslope contributing area per unit } \\
& \text { contour length, in meters, and } \\
& \tan \beta \text { is the local slope. }
\end{aligned}
$$

and is typically calculated on a spatially distributed basis using DEMs. High values of the TWI indicate locations that have large contributing areas and low slopes and that are likely to be saturated; areas with high TWI values often are found along streams, in areas of groundwater discharge, and wetlands (fig. 3) (Wolock and Price, 1994). Low values of TWI indicate areas unlikely to be saturated, with small contributing areas and high slopes; areas with low TWI values typically are found at the top of hillslopes and in areas of groundwater recharge. In many versions of TOPMODEL (including the version used in this investigation), the TWI is used to group hydrologically similar areas in the watershed; calculations then are performed in a semi-distributed manner on the groups rather than on a fully distributed basis.

In TOPMODEL, the vertical profile of hydraulic conductivity is assumed to follow an exponential decay of the form:

$$
K_{z}=K_{0} e^{-\frac{n_{\text {drain }}}{m}}
$$

where

$$
\begin{aligned}
& K_{z} \quad \text { is the hydraulic conductivity at depth } z \text {, in } \\
& \text { millimeters per hour; } \\
& K_{0} \quad \text { is the hydraulic conductivity at the surface, in } \\
& \text { millimeters per hour; } \\
& m \text { is a scaling parameter, in millimeters; } \\
& n_{\text {drain }} \quad \text { is the readily drained soil porosity; and, } \\
& z \quad \text { is the depth from the surface, in millimeters. }
\end{aligned}
$$

A steady-state approximation of conservation of mass (continuity) and Darcy's law is applied using the TWI and the exponential conductivity profile to calculate subsurface flow and storage.

TOPMODEL equations generally are defined in terms of the saturation deficit, a measure related to depth to the saturated zone; the saturation deficit is equal to the depth to water table multiplied by the readily drained soil porosity. The saturation deficit at a specific location is related to, and can be calculated from, the watershed-average saturation deficit:

$$
S_{x}=\bar{S}+m\left(\Lambda-T W I_{x}\right)
$$

where

$S_{\frac{x}{S}} \quad$ is the local saturation deficit, in millimeters;

$\bar{S}$ is the watershed-average saturation deficit, in millimeters;

$m$ is a scaling parameter, in millimeters;

$\Lambda \quad$ is the watershed average topographic wetness index, in $\ln$ (meters); and

$T W I_{x} \quad$ is the local topographic wetness index, in $\ln$ (meters).

\section{TOPMODEL Streamflow-Generation Concepts}

The main forcing mechanism for streamflow generation in TOPMODEL is precipitation, and an accurate precipitation record is required as input to TOPMODEL for accurate runoff prediction (Beven, 2001). TOPMODEL uses variable-source area runoff-generation mechanisms to model streamflow, including base flow, return flow, runoff generated from 


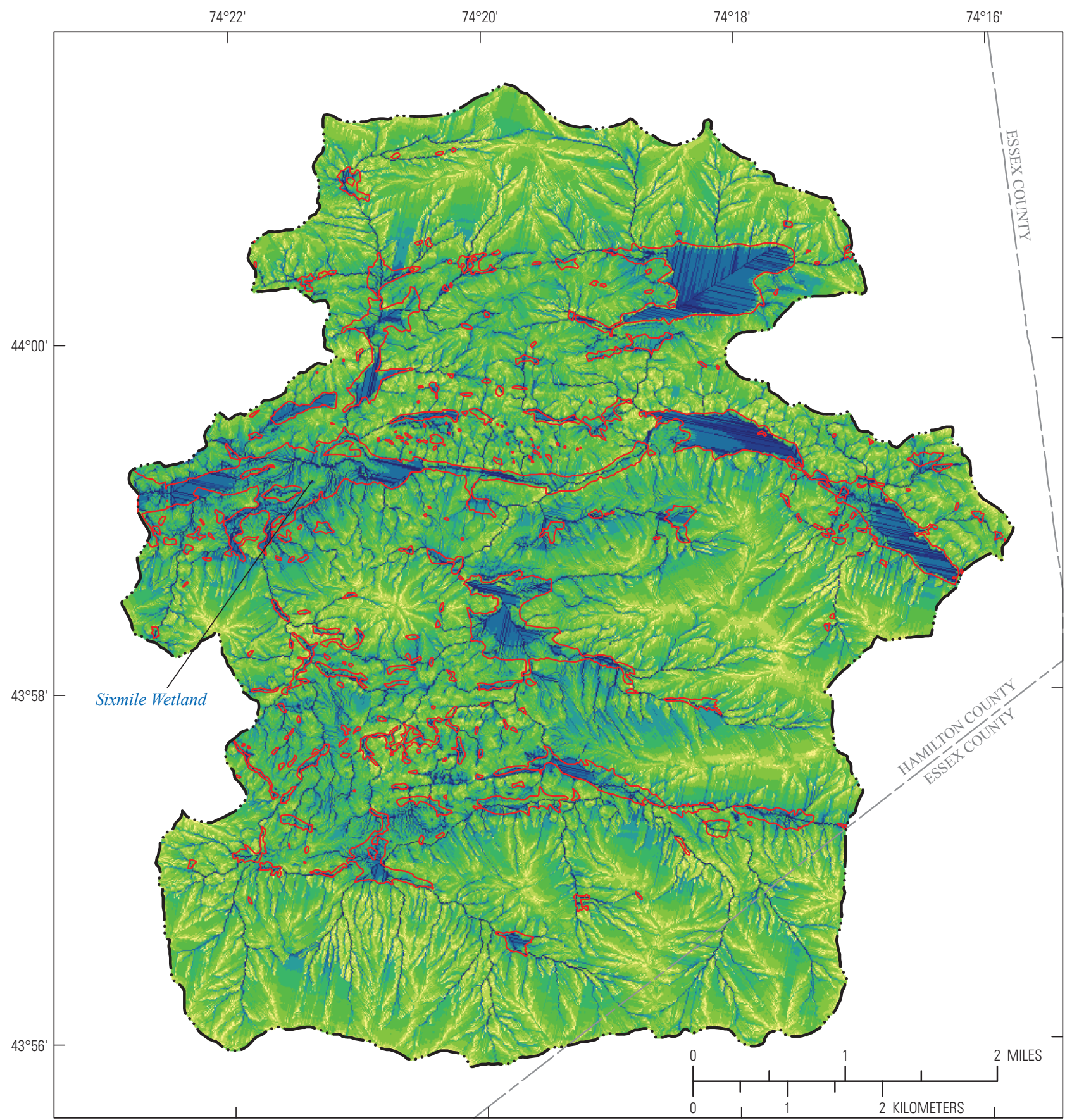

Base from National Elevation Dataset, 2009, 1/3 arc-second Universal Transverse Mercator projection Zone 18

Wetlands from New York State Adirondack Park Agency, Adirondack Park Freshwater Wetlands, 2000, 1:24,000

\section{EXPLANATION}

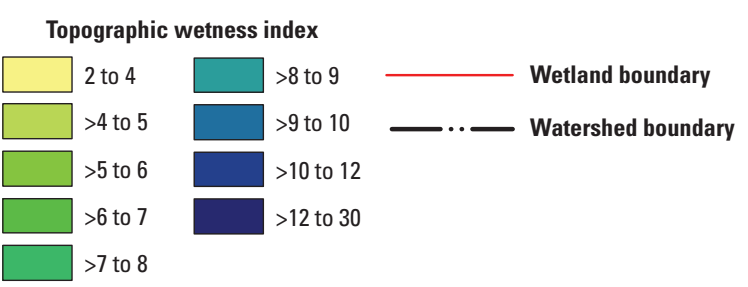

Figure 3. Topographic wetness index and wetland areas in the Fishing Brook study area, New York. 
precipitation on saturated areas, and direct precipitation on open water. TOPMODEL uses two main conceptual subsurface stores of water: an unsaturated zone and a saturated zone; runoff is generated only from the saturated zone. The location of the interface between the two zones corresponds to the saturation deficit and controls the types and amounts of flow generated by the model.

Potential evapotranspiration is calculated using the Hamon method (Hamon, 1961). Precipitation that falls is first used to satisfy potential evapotranspiration, and then infiltrates into the unsaturated zone and may drain to the saturated zone; a macropore-flow term allows a percentage of precipitation to infiltrate directly to the saturated zone. Evapotranspiration, when not satisfied from precipitation, is taken from the root zone at a rate proportional to the root-zone storage (Beven and others, 1995). Precipitation that falls on open water areas (including lakes and streams) immediately becomes streamflow. To account for attenuation in lakes, an exponential decay function is applied to the portion of flow in the watershed that drains through lakes.

Water from the saturated zone drains to streams as base flow based on the steady-state application of continuity and Darcy's law. The saturation deficit is calculated for each TWI value; when the saturation deficit is less than zero for a given TWI, the saturated zone reaches the land surface, and the portion of flow in the saturated zone equivalently "above" the land surface becomes return flow. If precipitation falls on areas with a saturation deficit equal to or less than zero, the precipitation becomes saturation overland flow. Runoff generated by infiltration excess occurs when the precipitation intensity exceeds the infiltration capacity.

\section{Previous Studies}

TOPMODEL is more a conceptual framework for simulating hydrological processes than a single, defined model, and can be modified to meet different goals (Beven, 1997). While most applications have calibrated TOPMODEL and evaluated its goodness-of-fit to streamflow data, others have explored how well the model can simulate distributed water-table levels and their variation in time (Moore and Thompson, 1996; Seibert and others, 1997; Blazkova and others, 2002). TOPMODEL predictions of water-table levels are of specific interest in the current (2011) study because of the role of shallow groundwater flow in transporting $\mathrm{Hg}$ to nearby streams and because saturated, organic-rich surface soils are known to be important in the geochemical cycling of mercury.

Several investigations have applied TOPMODEL to simulate stream-water quality through flow-path partitioning driven by model output, the development of surrogate indexes, or by linking with a biogeochemical model (Wolock and others, 1989; Robson and others, 1992; Band and others, 1993; Hornberger and others, 1994; Page and others, 2007). Of particular interest in the current study are previous attempts to use TOPMODEL to simulate dissolved organic carbon (DOC) concentrations in stream water as described by Hornberger and others (1994) and Boyer and others (1996). In these studies, the depth of the water table derived from daily saturation-deficit predictions combined with porosity were used to simulate the higher DOC concentrations observed in a Rocky Mountain river during snowmelt than during base flow. The response was modeled as a flushing process of DOC from shallow soils where the saturation deficit was used to quantitatively partition flow into shallow- and deep-flow compartments. The approach described above is potentially useful in the NAWQA Hg study because the transport of $\mathrm{Hg}$ from soils to streams is strongly controlled by and associated with the transport of DOC.

\section{Specific TOPMODEL Version}

The specific version of TOPMODEL used in this investigation is adapted from the FORTRAN code used in the Water Availability Tool for Environmental Resources (WATER), documented by Williamson and others (2009) and Kennen and others (2008). This version was derived from the original Beven and Kirkby (1979) version by Hornberger and others (1985) and adapted by Wolock (1993). A parallel investigation to this study, Feaster and others (2010), applied TOPMODEL in a South Carolina Coastal Plain watershed, and also includes an application of the grid-based mercury model (GBMM). Schelker and others (2011) also applied this version of TOPMODEL in the Fishing Brook Watershed for the period January 1, 2006, to June 16, 2008, in conjunction with water-quality sampling and observation of saturated areas for prediction of stream-water $\mathrm{Hg}$ concentrations. The version of TOPMODEL used in this study and in Schelker and others (2011) differs in two ways from that in Feaster and others (2010): in the current study, flow generation from impervious surfaces is not used (impervious surfaces cover less than 1 percent of the study area), and an internal snow accumulation and melt routine was activated.

Snow accumulation and melt routines in the model operate on a simple degree-day basis, computing the equivalent water depth of the snowpack using a cutoff temperature, which is compared to the daily mean air temperature. When the daily mean temperature is less than the cutoff temperature, any precipitation that falls is added to a water-equivalent snowpack. When the daily mean temperature is greater than the cutoff temperature, melting or partial melting of the accumulated snowpack occurs. The maximum melt for any day is limited by the available snowpack-water equivalent. Routines are included in the model for melt owing to temperature alone and melt owing to the combined effects of temperature and rain. Snowmelt owing to temperature alone is calculated using an air-temperature index method (equation 4). This temperature-index method is best suited for use in heavily forested areas (greater than 80 percent forested; 87 percent of the study area is forested) where the effects of 
wind and shortwave radiation are not significant factors in snowmelt (U.S. Army Corps of Engineers, 1998).

$$
M_{t}=C_{m}\left(T_{\text {mean }}-T_{\text {cut }}\right)
$$

where

$$
\begin{array}{cl}
M_{t} & \begin{array}{l}
\text { is the amount of melt, in millimeters per day; } \\
C_{m}
\end{array} \quad \begin{array}{c}
\text { is a melt-rate coefficient, in millimeters per } \\
\text { degrees Celsius per day; }
\end{array} \\
T_{\text {mean }} & \begin{array}{l}
\text { is the daily mean air temperature, in degrees } \\
\text { Celsius; and }
\end{array} \\
T_{\text {cut }} & \begin{array}{l}
\text { is a cutoff or base temperature, in degrees } \\
\text { Celsius. }
\end{array}
\end{array}
$$

The melt-rate coefficient (equation 4) is related to the density of the snowpack; it varies with geographic location and can change over time (Gray and Prowse, 1992). Typical values are 1.8 to $3.7 \mathrm{~mm}$ per degree Celsius per day for forested watersheds with higher values in less forested areas or windy conditions (U.S. Army Corps of Engineers, 1998). The melt-rate coefficient and base-temperature values both are specified as model-input parameters and can be calibrated in TOPMODEL.

Daily melt owing to rain on snow incorporates a simple energy-budget approach:

$$
M_{r}=(33.833+0.0126 P)\left(T_{\text {mean }}-T_{\text {cut }}\right)+1.27
$$

where $\quad M_{r} \quad$ is the amount of melt, in millimeters per day;

$P \quad$ is the daily precipitation, in millimeters per day;

$T_{\text {mean }} \quad$ is the daily mean air temperature, in degrees

Celsius; and

$T_{\text {cut }} \quad$ is a cutoff or base temperature, in degrees Celsius.

The energy-budget approach is practicable for use in the case of rain on snow because it can be assumed that the air is water-saturated and that cloud cover minimizes the effects of solar radiation (U.S. Army Corps of Engineers, 1998).

\section{Observed Data}

Data observed in the Fishing Brook Watershed were used as input to TOPMODEL and to evaluate model simulations. Many sources of data were available in Fishing Brook Watershed and the surrounding area, including locally observed data and remotely sensed data.

\section{Input Data for Model Processing}

To model streamflow, TOPMODEL uses three main input sets including (1) a time series of meteorological data, (2) the TWI distribution, and (3) model parameters, including watershed characteristics and calibration parameters.

\section{Meteorological Data}

Meteorological data required to run TOPMODEL include precipitation and temperature; daily total precipitation and daily average temperatures were used. Several sources of meteorological data are available near the study area, including collocated National Atmospheric Deposition Program (NADP) and Clean Air Status and Trends Network (CASTNET) sites, $3.8 \mathrm{~km}$ from the outlet of the study area (fig. 1). The NADP and CASTNET sites are located in a clearing that is at approximately the same elevation as the outlet of the study area (approximately $500 \mathrm{~m}$ ) and is located slightly downstream of the study area in the Fishing Brook Watershed.

\section{Precipitation}

Daily total precipitation amounts used in the model were from the National Atmospheric Deposition ProgramNational Trends Network (NADP-NTN) site NY20 (National Atmospheric Deposition Program, 2009; data available at http://nadp.sws.uiuc.edu/), at which precipitation was measured using a Belfort weighing bucket and recorded on a daily basis. Daily data were recorded from midnight to midnight, eastern daylight time. Other time-series data that were recorded at more frequent intervals, such as temperature and streamflow, were averaged on a daily basis to match the recording period of the precipitation data. Data were quality assured by the NADP-NTN (quality-assurance plans available at http://nadp.sws.uiuc.edu/lib/qaPlans.aspx). Precipitation amounts recorded as "trace" by NADP-NTN were included in the model as 0.005 inch $(0.13 \mathrm{~mm})$, or half of the minimum recordable amount of the instrument. Data that were missing or screened as invalid by the NADP-NTN were replaced by a secondary precipitation record collected by CASTNET, which was recorded at 1-hour intervals and summed to a daily time step (Clean Air Status and Trends Network, 2010). For the period January 25, 2005, to September 30, 2009, 933 days of valid precipitation data from NADP-NTN were used in the model; the remaining 47 days of record were filled in with the secondary CASTNET record.

\section{Temperature}

Daily average temperature for use in the model was calculated from hourly values recorded at Huntington Wildlife Forest, CASTNET site HWF187 (Clean Air Status and Trends Network, 2010, data available at http://java.epa.gov/ castnet/epa_jsp/prepackageddata.jsp). Ambient temperature was measured at $9 \mathrm{~m}$ above ground surface using a platinum resistance-temperature device. Hourly temperature values were quality assured by CASTNET, screened before use based on the resulting data-quality indicator, and averaged to compute daily values. If more than two hourly values were missing from the record or were quality assured as invalid, data for that day were replaced with data from a secondary record. For the period January 25, 2005, to September 30, 
2009, 961 days of valid temperature data from CASTNET were used in the model. The secondary record of temperature data was recorded daily by the State University of New York College of Environmental Science and Forestry (SUNY-ESF) at a site collocated with the CASTNET site and was used for the remaining 19 days (Myron J. Mitchell., SUNY-ESF, unpub. data, 2010, information available at http://www.esf. edu/hss/huntington_forest_research_overview.htm).

\section{Topographic Wetness Index}

TWI distributions were computed from the National Elevation Dataset (NED) 1/3 arc-second dataset (Gesch and others, 2002, data available at http://seamless.usgs.gov/). The horizontal resolution of the NED 1/3 arc-second dataset is approximately $10 \mathrm{~m}$. The NED raster data were processed in Environmental Systems Resource Institute (ESRI) ARCGIS using Spatial Analyst tools and the Raster Calculator. Sinks, or cells in the DEM that are lower than all surrounding cells, were filled to the level of the lowest surrounding cell to ensure that the resulting derived hydrology network was continuous. Downslope-flow directions were determined from the filled DEM as the direction from a cell to its steepest downslope neighboring cell. Specific accumulated area for each cell, $\alpha$ (equation 1), was computed from the flow-direction raster; the number of accumulated cells was computed, which then was multiplied by the area per cell and divided by the cell width, in meters. Cell slopes, $\tan \beta$ (equation 1), were calculated from the percent slope calculated by the Spatial Analyst Surface Slope function. Cells with a slope value of zero were replaced with a small value (0.01) because a value of zero would cause the computed TWI value to equal infinity. The TWI value for each cell (fig. 3) then was computed as the natural log of the specific accumulated area divided by the slope ratio using the Raster Calculator. The TWI was clipped to the watershed shapefile and exported as a text file for processing into frequency distributions. The relative frequency distributions of TWI were computed using 30 equal-width bins (fig. 4).

\section{Model Parameters}

In addition to TWI, TOPMODEL uses several model parameters that reflect the hydrology, soils, and location of the study area (table 1). The values of each of these model parameters can be calibrated or set as fixed values based on available information; in this application, fixed values were used for model parameters based on spatial data such as soils and elevation, and parameters based on non-measured values were calibrated. Model parameters that were set based on available data are referred to herein as watershed characteristics; the remaining parameters are referred to as calibration parameters.

\section{Watershed Characteristics}

Watershed characteristics used in TOPMODEL include areas of the watershed, lakes, and streams; the drainage area upstream of lakes; the latitude of the watershed; and soil properties (table 1). Watershed boundaries were digitally delineated from 1:24,000 scale digital contours, with modifications based on field observations in select areas with low slope drainage divides. Lake areas were calculated

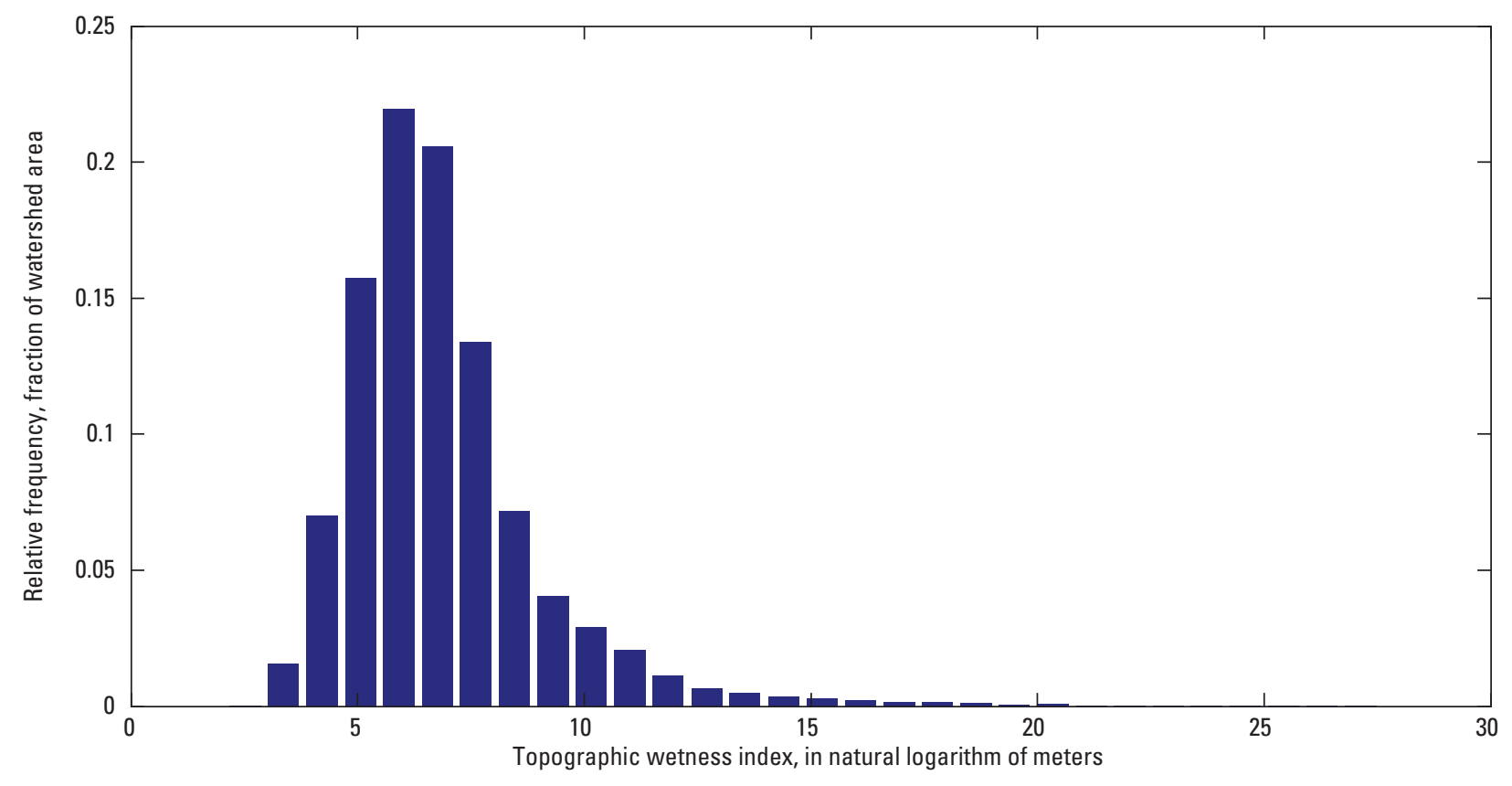

Figure 4. Relative frequency distribution of the topographic wetness index for the Fishing Brook study area, New York. 
Table 1. TOPMODEL calibration parameters, watershed characteristics, and data sources for the Fishing Brook study area, New York.

[APA Freshwater Wetlands (New York State Adirondack Park Agency, 2000); NHD, National Hydrography Dataset (U.S. Geological Survey, 2008); SSURGO, Soil survey geographic database (Natural Resources Conservation Service, 2009); NED, National Elevation Dataset (Gesch and others, 2002); --, calibrated value]

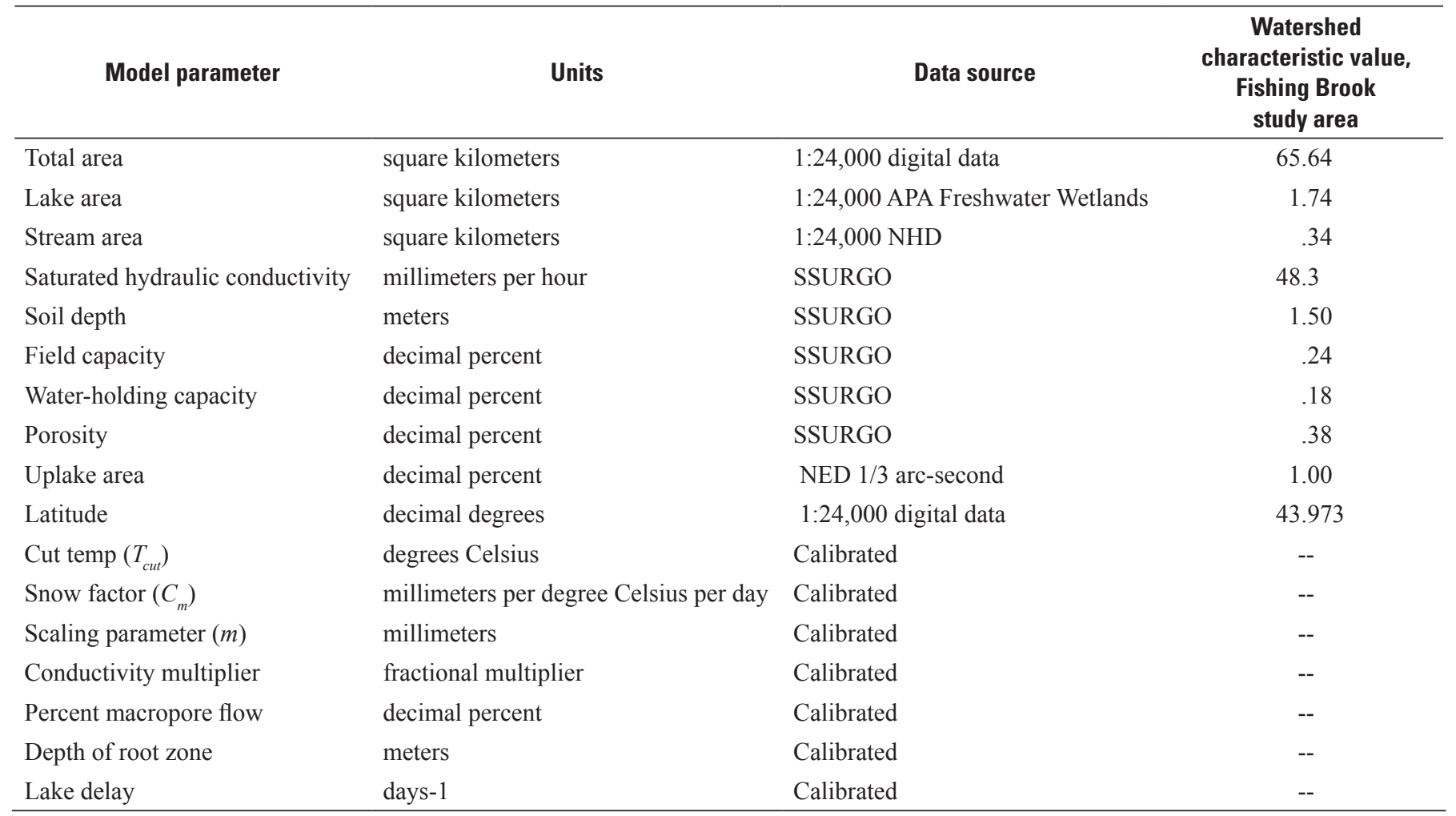

from the open water class of the 1:24,000 Adirondack Park Freshwater Wetlands shapefile (New York State Adirondack Park Agency, 2000). The drainage area upstream of lakes was calculated using basins delineated at the outlets of each of the three largest open water bodies in the study area-Pickwacket Pond, County Line Flow, and Fishing Brook Flow (fig. 1). Stream area was calculated using the 1:24,000 National Hydrography Dataset (NHD) (U.S. Geological Survey, 2008), assuming an average stream width of $5 \mathrm{~m}$.

Soil properties, including saturated hydraulic conductivity, soil depth, field capacity, water-holding capacity, and porosity, were computed from the Soil Survey Geographic (SSURGO) Database (National Resources Conservation Service, 2009, data available at http://soildatamart.nrcs.usda. gov/). SSURGO tabular data for each map unit were extracted by soil component and horizon and weighted for depth and area. Rock outcrops and open water were excluded from the soil-property calculations.

\section{Calibration Parameters}

Some model-parameter values could not be set using available data because measurements or values were not available, and these parameters were therefore calibrated; they included snowmelt model parameters, the scaling factor $(\mathrm{m})$, the conductivity multiplier (conmult), percent macropore flow (pmac), root zone depth (zroot), and lake delay factor (rip_decay). Snowmelt model parameters, $T_{\text {cut }}$ and $C_{m}$, control the threshold between snow accumulation and melt and the rate of snowmelt per degree above that threshold. The scaling parameter, $m$, is one of the most important TOPMODEL parameters (Beven and others, 1995); it controls the rate of decrease of the vertical profile of hydraulic conductivity and has important effects on the slope of the recession curve. The conductivity multiplier represents the comparative difference between the mean and maximum hydraulic conductivity of the soil. The percent macropore flow parameter represents the portion of flow that is routed directly to the saturated zone from the surface, bypassing the unsaturated zone; this value is difficult to determine from field observations. The lake delay parameter controls the relative magnitude and duration of flow attenuation through lakes. The depth of root zone parameter controls the depth of the zone in which water is available to satisfy potential evapotranspiration; no measurements of representative root zone depth were available in the study area. 


\section{Unused Model Parameters}

Several model parameters are included in the FORTRAN code as documented by Feaster and others (2010), Williamson and others (2009), and Kennen and others (2008) that were not used in this application of TOPMODEL. Unused model parameters mainly described human impacts on the watershed, including impervious area-runoff controls (impervious area covers less than 1 percent of the study area) and groundwater and surface-water withdrawals from and discharges to the watershed. An additional channel-routing parameter described in Schelker and others (2011) is included in the input file for this version of TOPMODEL, but is implemented in a separate section of the WATER toolbox and is not used in the TOPMODEL code.

\section{Observed Streamflow and Depth to Water Table for Model Evaluation}

Streamflow and depth to water table measured in the study area were used to assess TOPMODEL predictions of streamflow and saturation deficit.

\section{Streamflow}

Streamflow in the study area was gaged at the outlet of County Line Flow, USGS streamgage 0131199050 (fig. 1), from January 25, 2007, through early 2010 using a standard stage-discharge rating (U.S. Geological Survey, 2011).

Streamflow data were collected at 15 -minute intervals and summed to match the daily time period of the NADP daily precipitation data. For comparability among watersheds and subwatersheds in this area and others, streamflow (with units of volume per unit time) will be discussed throughout this report in terms of runoff, which is equal to streamflow normalized by the drainage area, and has units of length per unit of time.

Runoff in the study area shows significant seasonal patterns (fig. 5). At the Hudson River near Newcomb (station 01312000, fig. 1), a nearby USGS streamgage with a long period of record, the long-term median of monthly mean runoff values (fig. 5) varies from a minimum of $0.72 \mathrm{~mm} / \mathrm{d}$ in February to a maximum of $5.74 \mathrm{~mm} / \mathrm{d}$ in April (U.S. Geological Survey, 2010). Measured runoff for Fishing Brook during the modeling period showed seasonal trends

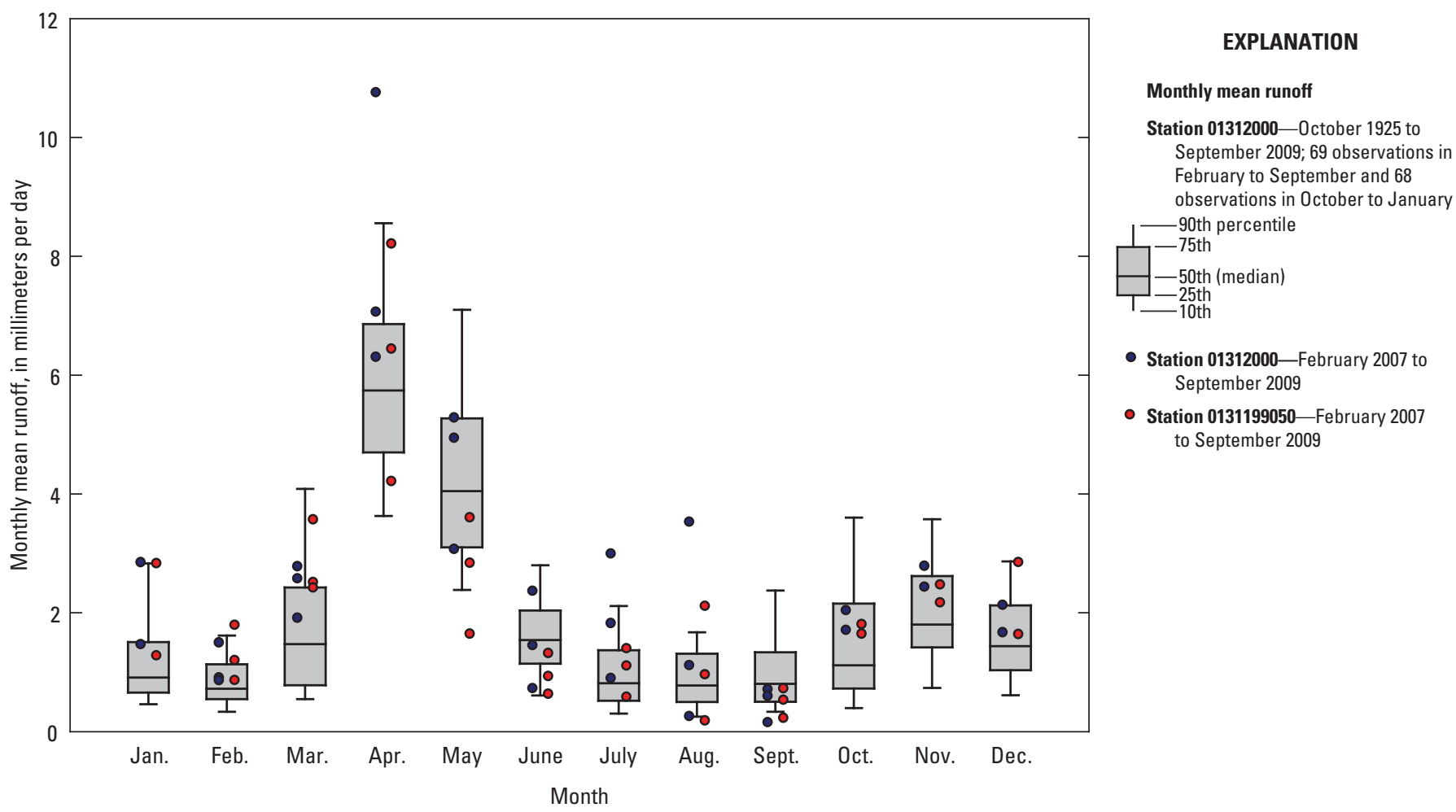

Figure 5. Monthly mean runoff at U.S. Geological Survey streamgages 01312000, Hudson River near Newcomb, New York, and 0131199050, Fishing Brook at County Line Flow near Newcomb, New York. 
similar to those observed at the Hudson River near Newcomb during the same time period (fig. 5). The median daily runoff for the Fishing Brook study area during the modeling period was $1.27 \mathrm{~mm} / \mathrm{d}$; the minimum daily runoff was $0.077 \mathrm{~mm} / \mathrm{d}$, occurring on September 5, 2007; and the maximum daily runoff was $23.5 \mathrm{~mm} / \mathrm{d}$, occurring on April 24, 2007.

\section{Depth to Water Table}

Depth to water table was measured in Sixmile Wetland (fig. 6) during April-September 2009 using 3.8-cm diameter piezometers. Thirty-seven piezometers were installed between USGS stations 0131199021 and 0131199022 (SS05 and SS04, respectively, fig. 2) in two main north/south transects across the eastern end of the wetland, with two smaller additional groups of piezometers installed close to Sixmile Brook. The piezometers were installed and developed during fall 2008 and had a $30.5 \mathrm{~cm}$ slotted section that typically was installed approximately 50 to $80 \mathrm{~cm}$ below ground surface.
Two types of water-level measurements were made using the piezometers: absolute depth to water table and a time series of relative depth-to-water-table fluctuations. The two types of depth-to-water-table measurements were used to address two components of depth-to-water-table predictions from TOPMODEL: depth-to-water-table measurements were used to better approximate the quantitative saturation deficit in the study area, and the water-table fluctuations were used to assess the ability of the model to reproduce water-table fluctuations over time in the study area.

Depth to water table was measured using electric tapes in 27 of the wells at least once. Three groups of depth to water measurements were made (fig. 7): on May 5 and 6 (24 piezometers measured, median depth to water $232 \mathrm{~mm}$ ), May 19 and 20 (24 piezometers measured, median depth to water $104 \mathrm{~mm}$ ), and August 13, 2009 (20 piezometers measured, median depth to water $279 \mathrm{~mm}$ ). Twenty piezometers were measured during all three sets of measurements, one piezometer was measured twice, and six piezometers were measured once.

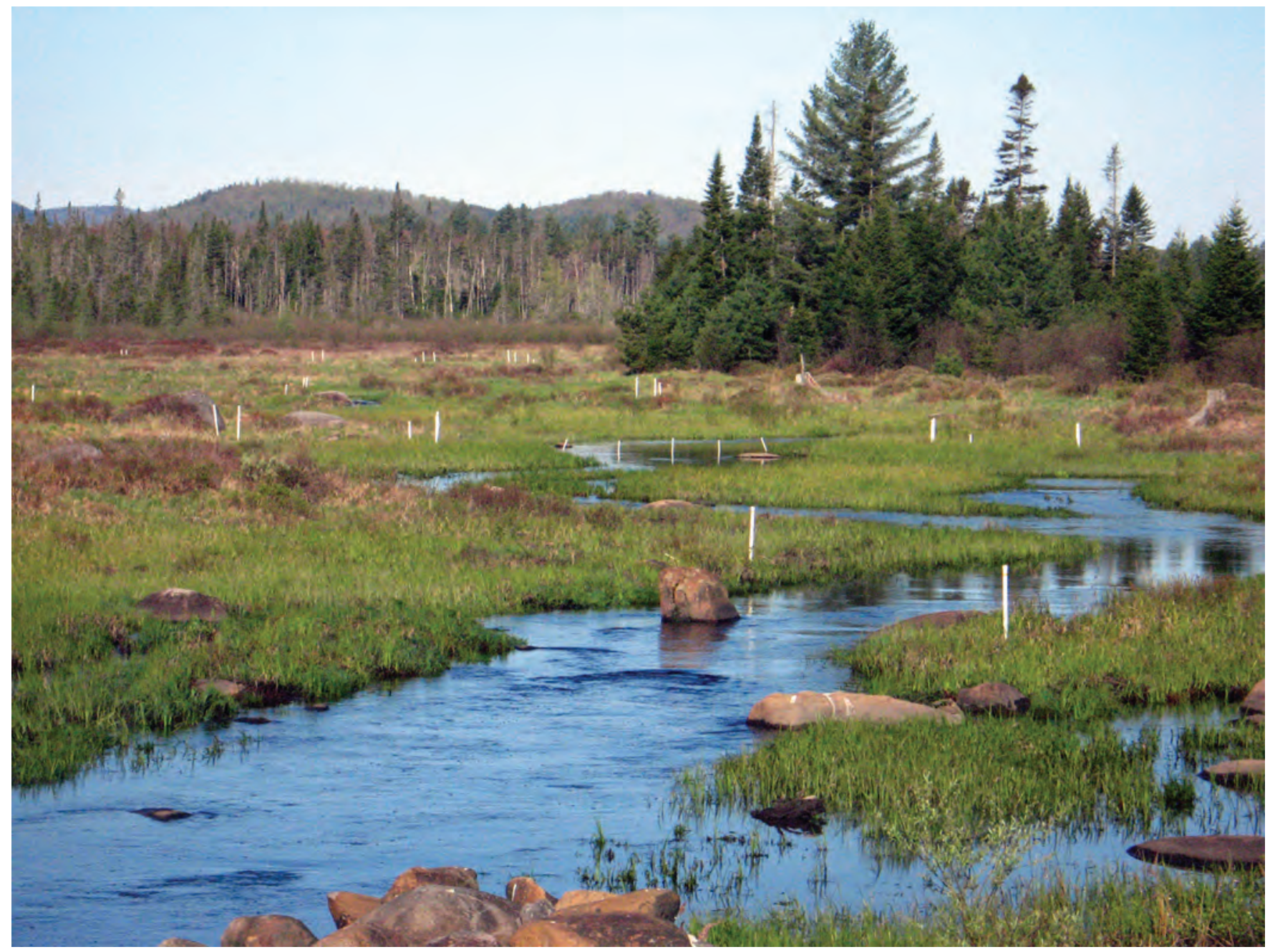

Figure 6. Sixmile Wetland with depth-to-water-table piezometers, May 2009. Photograph taken from site SS04, looking west towards sites SS05, MA08, and MA09. 


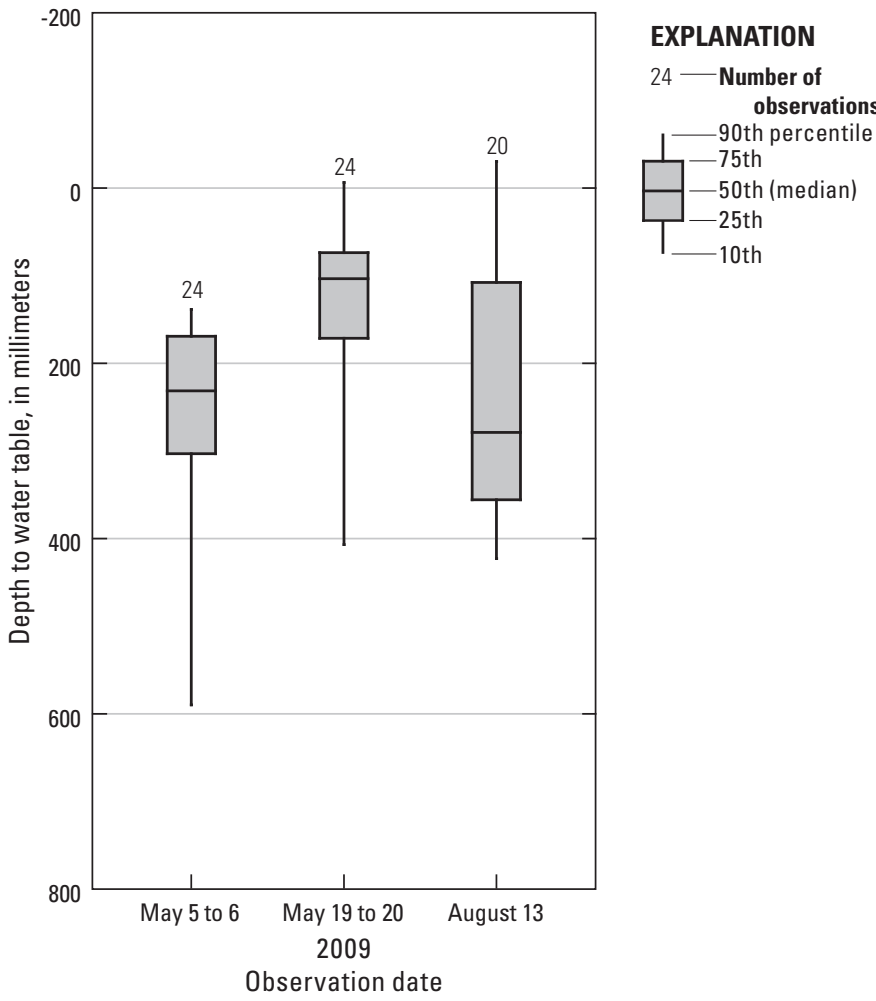

Figure 7. Observed depth to water table at Sixmile Wetland, Fishing Brook study area, New York, May and August 2009.
Water-table fluctuations were logged in seven piezometers from April 23 to September 25, 2009, using non-vented submersible pressure transducers at 15 -minute intervals. Measured pressure data were converted to water depth above transducer by subtracting barometric pressure and using water density calculated from temperature data logged by the pressure transducers. The 15-minute data were averaged to a daily time step for use with TOPMODEL results. Depth-to-water-table data collected after August 27, 2009, were not used in the TOPMODEL calibrations because of a backwater effect created in the wetland by the construction of a beaver dam at the outlet of Sixmile Wetland. Slug tests were conducted on July 30 and 31, 2009; data from these two days were excluded from the depth-to-water-table calculations.

Depth-to-water-table time series are compared among wells and to TOPMODEL output by subtracting the average depth of water from each time series (fig. 8). The median of the range recorded in each piezometer over time was $41.5 \mathrm{~mm}$, or 3.7 times the median of the daily range among piezometers.

\section{TOPMODEL Calibration}

TOPMODEL was used to simulate runoff on a daily time step for the Fishing Brook Watershed during the period January 25, 2007-September 30, 2009. The period October 1, 2005-January 24, 2007, was used to condition (or initialize) the model. Calibration of TOPMODEL was accomplished

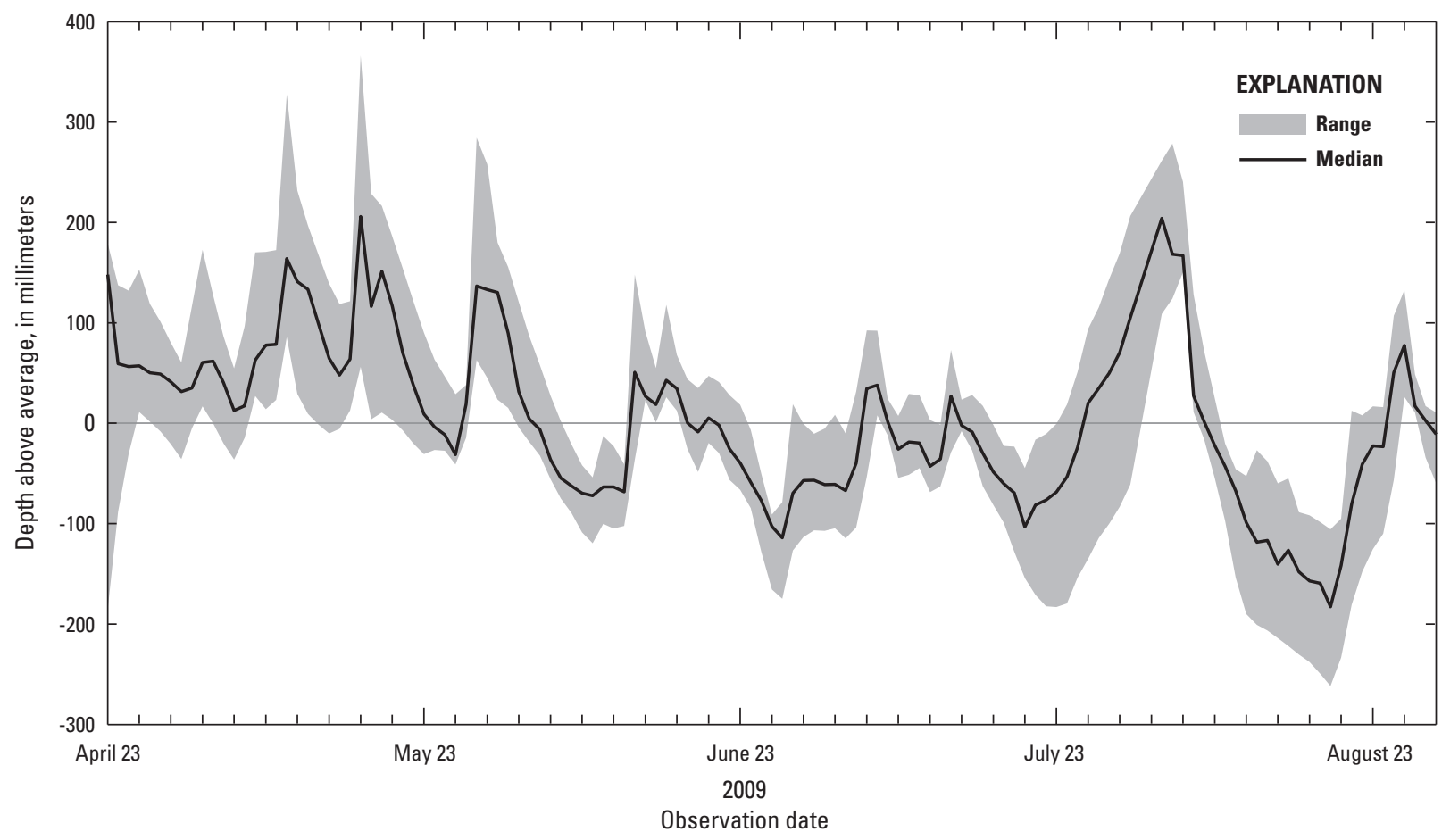

Figure 8. Observed depth-to-water-table fluctuations at Sixmile Wetland, Fishing Brook study area, New York, April-August 2009. 
in two steps: first, snowmelt parameters were calibrated to runoff; second, these snowmelt parameters were held at fixed values as the remaining parameters were calibrated to runoff and depth to water table using a combined multipleobjective function. A non-directed Monte-Carlo optimization, using parameter values randomly selected from uniform distributions, was used for both calibration steps. Sensitivity analyses and a simplified prediction-interval uncertainty analysis were used to evaluate the results.

Model output is evaluated by comparison to measured runoff and depth to water table using several goodness-of-fit statistics including (1) the Nash-Sutcliffe model efficiency (Nash and Sutcliffe, 1970), (2) Pearson's correlation coefficient (r), (3) the root mean squared error (RMSE), (4) the bias, and (5) the mean absolute error (MAE). The definitions for the goodness-of-fit statistics are expressed below in terms of runoff; depth to water table also can be substituted where appropriate.

The Nash-Sutcliffe coefficient of model-fit efficiency, $E$, is defined as

where

$$
E=1-\frac{\sum_{i=1}^{N}\left(Q o_{i}-Q s_{i}\right)^{2}}{\sum_{i=1}^{N}\left(Q o_{i}-\overline{Q o}\right)^{2}}
$$

$N \quad$ is the number of time steps in the simulation period,

$Q o_{i} \quad$ is the observed runoff for time step $i$,

$\overline{Q o}$ is the mean observed runoff for the simulation period, and

$Q s_{i} \quad$ is the simulated runoff for time step $i$.

The Nash-Sutcliffe coefficient of model-fit efficiency, $E$, can emphasize the effect of outliers and large flows (McCuen and others, 2006); to balance the emphasis on low flows, the Nash-Sutcliffe model efficiency of the natural log of runoff also is used to evaluate model output.

Pearson's correlation coefficient, $r$, is defined as

$$
r=\frac{\sum_{i=1}^{N}\left(Q o_{i}-Q o\right)\left(Q s_{i}-Q s\right)}{\sqrt{\sum_{i=1}^{N}\left(Q o_{i}-Q o\right)^{2}} \sqrt{\sum_{i=1}^{N}\left(Q s_{i}-Q s\right)^{2}}}
$$

where

$$
\begin{aligned}
& \overline{Q S} \text { is the mean observed runoff for the simulation } \\
& \text { period. }
\end{aligned}
$$

The RMSE is defined as

$$
R M S E=\sqrt{\frac{\sum_{i=1}^{N}\left(Q s_{i}-Q o_{i}\right)^{2}}{N}}
$$

The bias is defined as

$$
\text { bias }=\frac{\sum_{i=1}^{N}\left(Q s_{i}-Q o_{i}\right)}{N}
$$

The MAE is defined as

$$
M A E=\frac{\sum_{i=1}^{N}\left|Q s_{i}-Q o_{i}\right|}{N}
$$

\section{Snowmelt Calibration}

Values of the TOPMODEL parameters that affect snow accumulation and melt, $T_{C u t}$ and $C_{m}$, can change over time with the condition of the snowpack and melting mechanism (Gray and Prowse, 1992). Changing snow density, albedo, and internal snowpack energy, as well as varying atmospheric conditions and solar radiation can all affect $C_{m}$, the meltrate coefficient. Conditions preceding snowmelt events are likely to vary from year to year. Snowmelt parameters were therefore calibrated by individual water year (WY) separately from the main TOPMODEL parameters, allowing them to adjust to different melt conditions occurring in the watershed. TOPMODEL was run in 10,000 Monte-Carlo simulations for each WY; snowmelt parameters were assigned randomly from a uniform distribution within a specified range of values, and the remaining TOPMODEL parameters were set to fixed values (table 2). A 1-year period beginning October 1 of the previous WY was used to condition the model for each snowmelt calibration. In WY 2007, the conditioning period was effectively longer because runoff data were not available until January 25, 2007, and model output was therefore not evaluated for 116 days of WY 2007. From the 10,000 MonteCarlo runs for each WY, optimum snowmelt-parameter values were chosen using the Nash-Sutcliffe efficiency of runoff. The results of the individual WY snowmelt calibrations were applied to the observed rainfall record and then combined to generate a continuous equivalent liquid-precipitation record. In the equivalent liquid-precipitation record, the time of occurrence of precipitation was shifted during periods of modeled snowfall and snowmelt; precipitation that was modeled as falling snow was shifted to occur as input to TOPMODEL during a later modeled snowmelt period. A timeseries record of the equivalent water depth of the snowpack also was developed. The equivalent liquid-precipitation record then was used in the calibration of the remaining TOPMODEL parameters.

\section{Results of Snowmelt Calibration}

The results of the snowmelt calibration generally show good agreement with observed snowmelt-runoff events (figs. 9-11 and table 3). The maximum simulated snowpackwater-equivalent values for each winter during 2007-09 were 153,246 , and $116 \mathrm{~mm}$, respectively. Runoff in the calibration portion of WY 2007 (fig. 9) was dominated by a single spring snowmelt-runoff event, which was followed by a relatively dry period. The peak runoff for the event was matched well by the calibration results, but total volume of runoff for the event was underpredicted. Runoff in WY 2008 (fig. 10) was 
Table 2. Snowmelt calibration-parameter ranges and fixed values.

\begin{tabular}{llc}
\hline \multicolumn{1}{c}{ Model parameter } & \multicolumn{1}{c}{ Units } & Value or calibration range \\
\hline Cut temp $\left(T_{c u t}\right)$ & degrees Celsius & -2.22 to 1.67 \\
Snow factor $\left(C_{m}\right)$ & millimeters per degree Celsius per day & .457 to 4.57 \\
Scaling parameter $(m)$ & millimeters & 15 \\
Conductivity multiplier & multiplier & 3 \\
Percent macropore flow & decimal percent & .2 \\
Depth of root zone & meters & 1 \\
Lake delay & unitless & 1 \\
\hline
\end{tabular}

similarly dominated by the spring snowmelt-runoff event, but an additional mid-winter snowmelt event and several smaller non-snowmelt runoff events also occurred. Calibration results reproduce the form of the mid-winter event and the double-peaked form of the spring event well; however, a peak preceding the main spring snowmelt-runoff event was simulated, but not observed, and the magnitude of the spring event peaks was overpredicted. The smaller spring snowmeltrunoff peak in WY 2009 was more comparable to nonsnowmelt runoff events (fig. 11) than those in WYs 2007 and 2008. The magnitude of a mid-winter snowmelt-runoff event in WY 2009 was underpredicted, and a snowmelt-runoff event in March 2009 was overpredicted. An observed runoff event at the end of April 2009 was not predicted by the simulation.

The Nash-Sutcliffe efficiency of the snowmelt calibration was highest for WY 2007 (0.775), which had the shortest calibration period and most distinct snowmelt-runoff event, and lowest for WY 2009 (0.357), which had the least distinct snowmelt-runoff event (table 3). Nash-Sutcliffe efficiencies for WYs 2008 and 2009 also may have been affected by the occurrence of mid-winter snowmelt-runoff events, while in WY 2007, the snowmelt parameters were effectively calibrated to a single snowmelt-runoff event. In WYs 2008 and 2009, the snowmelt calibration included multiple snowmelt events, which may have been preceded by different snowpack conditions or caused by different snowmelt mechanisms. Calibration runs with the highest Nash-Sutcliffe model efficiencies were found in different areas of the snowmelt calibration-parameter space in each WY (table 3 and fig. 12). Figure 12 is a representation of the response surface for each snowmelt calibration, showing the Nash-Sutcliffe efficiency value for each combination of two parameters used. The calibrated value of $T_{\text {cut }}$ for WY 2007 was almost $1^{\circ} \mathrm{C}$ greater than for WYs 2008 or 2009 , and the calibrated value of the melt-rate coefficient, $C_{m}$, varied from $0.55 \mathrm{~mm}$ per degree Celsius per day in WY 2009 to $1.55 \mathrm{~mm}$ per degree Celsius per day in 2008. A discontinuity occurs in the $T_{\text {cut }}$ parameter space for the WY 2007 calibration at around freezing (fig. 12). The main snowmelt event for that year was preceded by 3 days of essentially equal average temperature (fig. 9), just below $0^{\circ} \mathrm{C} ; T_{\text {cut }}$ values even slightly below this temperature cause the snowmelt to occur too early, resulting in a sudden decrease in efficiency. Optimum $T_{\text {cut }}$ and $C_{m}$ values are not identified as clearly for the WY 2009 calibration as for WY 2007 or WY 2008; this may be because of a calibration conflict between a mid-winter snowmelt-runoff event (fig. 10) and a spring snowmelt-runoff event as a result of differences in snowpack conditions or snowmelt mechanisms (two bands of maxima occur in the Nash-Sutcliffe efficiency parameter space corresponding to the snowmelt events) or because of the relatively small magnitude of the main snowmelt event.

Table 3. Snowmelt calibration parameter and objective values, by water year.

[Water year, the 12-month period from October 1 through September 30. The water year is designated by the calendar year in which it ends; $T_{c u}$, cutoff temperature; $C m$, melt-rate coefficient; $\mathrm{mm}$, millimeter; $E$, Nash-Sutcliffe coefficient of model-fit efficiency; $E(\ln )$, Nash-Sutcliffe coefficient evaluated for the natural logarithm of a quantity; $r$, Pearson's correlation coefficient; RMSE, root mean squared error; MAE, mean absolute error]

\begin{tabular}{lccccccccc}
\hline Water year & $\begin{array}{c}\boldsymbol{T}_{\text {cur' }} \\
\text { degrees } \\
\text { Celsius }\end{array}$ & $\begin{array}{c}\boldsymbol{C}_{\mathbf{m}^{\prime}} \mathbf{m m} \\
\text { per degree } \\
\text { Celsius, per } \\
\text { day }\end{array}$ & $\begin{array}{c}\text { Time steps } \\
\text { in } \\
\text { evaluation }\end{array}$ & $\boldsymbol{E}$ & $\boldsymbol{E}(\mathbf{l n})$ & $\boldsymbol{r}$ & $\begin{array}{c}\text { RMSE, } \\
\mathbf{m m} \\
\text { per day }\end{array}$ & $\begin{array}{c}\text { Bias, } \\
\mathbf{m m}\end{array}$ & $\begin{array}{c}\text { MAE, } \\
\mathbf{m m}\end{array}$ \\
\hline 2007 & 0.3069 & 1.0054 & 249 & 0.775 & 0.553 & 0.901 & 1.30 & -0.520 \\
2008 & -.5883 & 1.5538 & 366 & .637 & .414 & .834 & 1.56 & -.210 & 1.02 \\
2009 & -.6890 & .5484 & 365 & .357 & .629 & .647 & 1.47 & -.467 \\
\hline
\end{tabular}



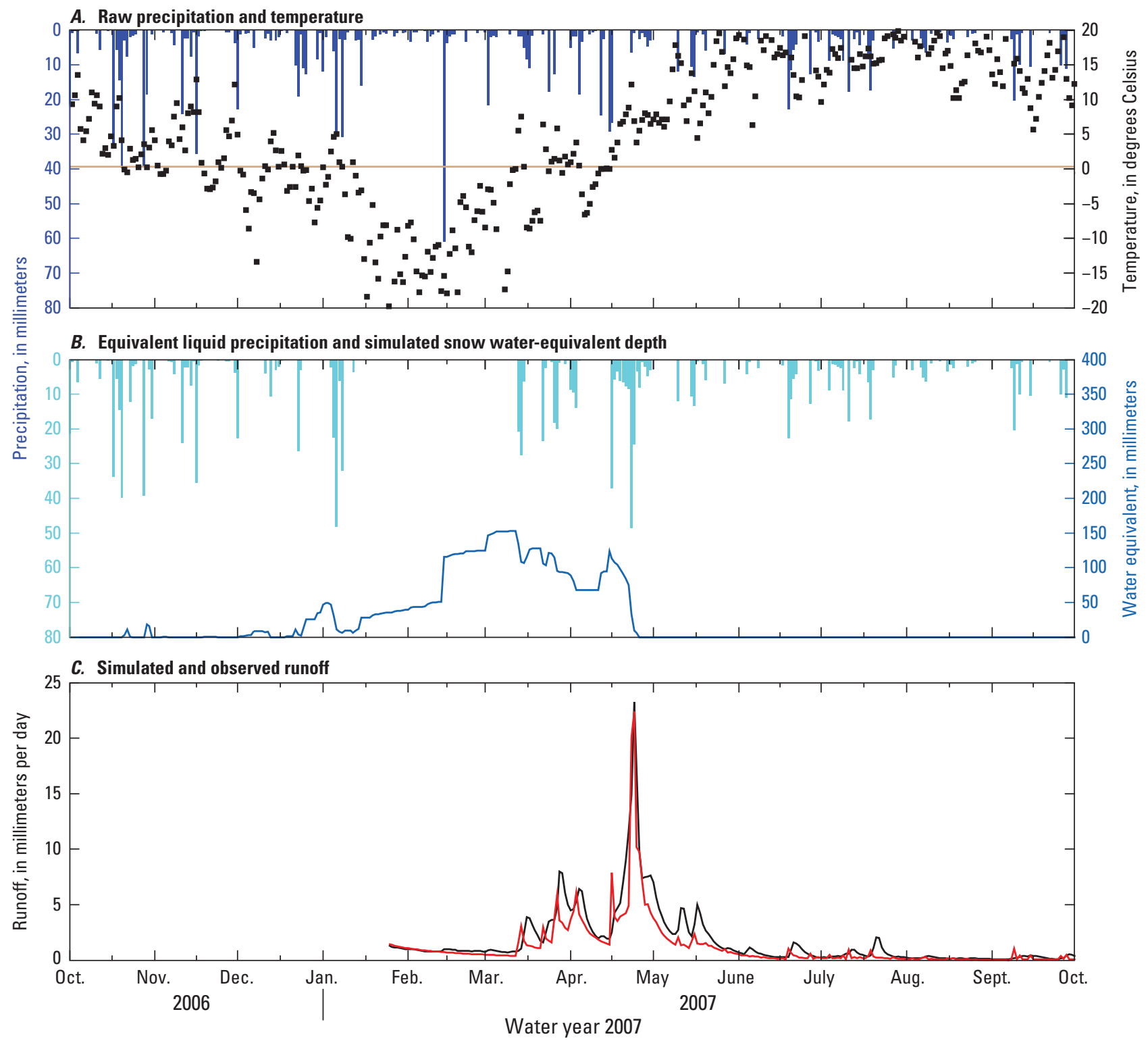

EXPLANATION

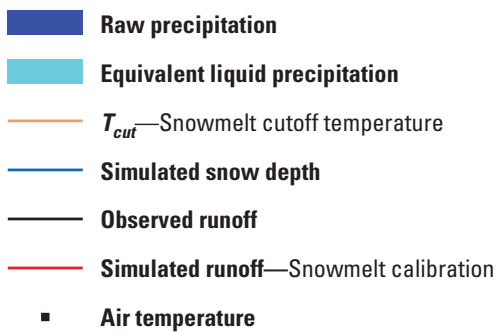

Figure 9. Snowmelt calibration $A$, raw precipitation and temperature, $B$, equivalent liquid precipitation and simulated snow water-equivalent depth, and $C$, simulated and observed runoff for Fishing Brook at County Line Flow near Newcomb, New York, water year 2007. 

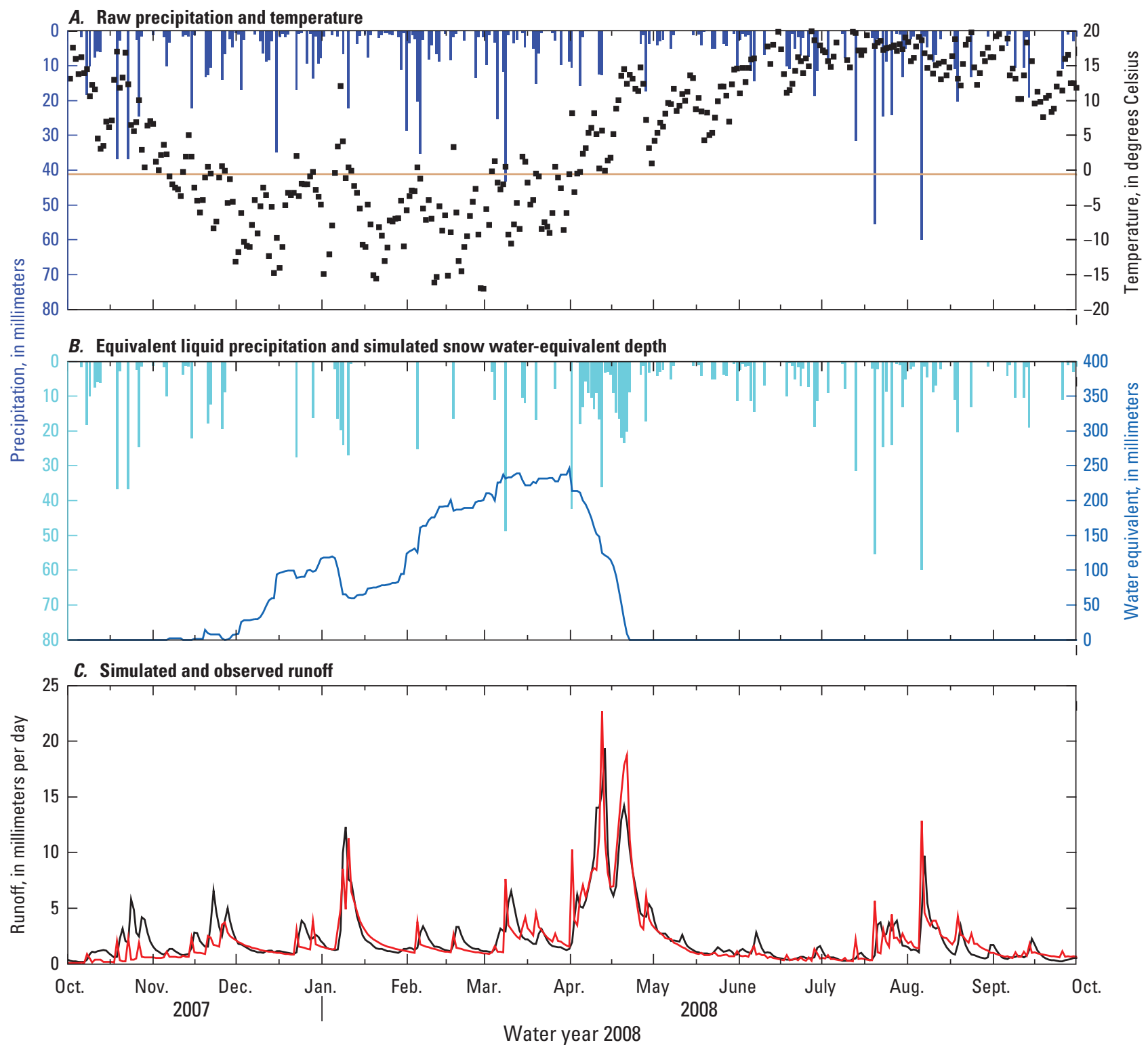

EXPLANATION

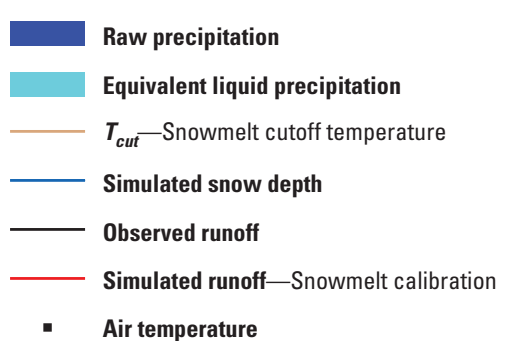

Figure 10. Snowmelt calibration $A$, raw precipitation and temperature, $B$, equivalent liquid precipitation and simulated snow water-equivalent depth, and $C$, simulated and observed runoff for Fishing Brook at County Line Flow near Newcomb, New York, water year 2008. 

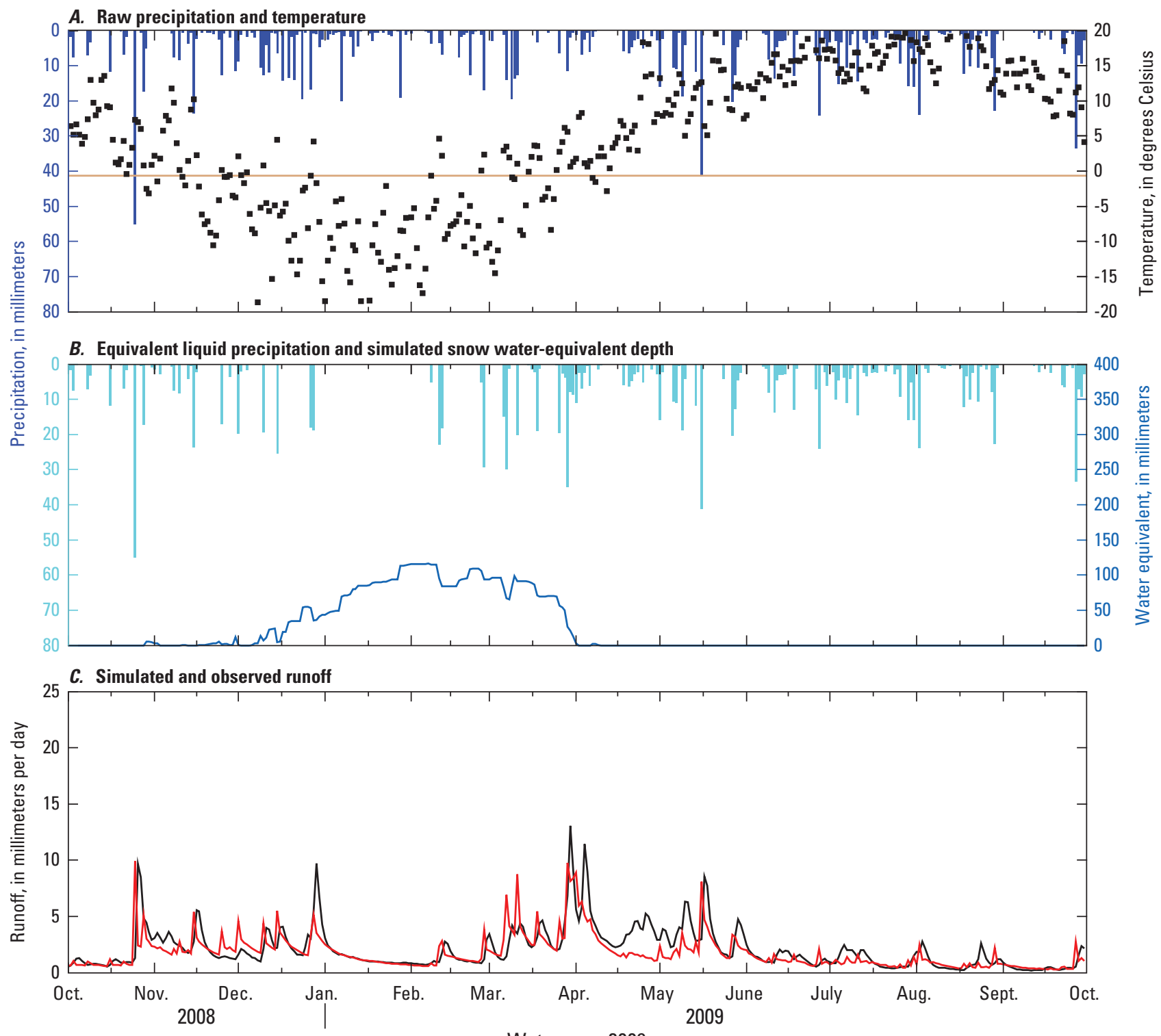

Water year 2009

EXPLANATION

Figure 11. Snowmelt calibration $A$, raw precipitation and temperature, $B$, equivalent liquid precipitation and simulated snow water-equivalent depth, and $C$, simulated and observed runoff for Fishing Brook at County Line Flow near Newcomb, New York, water year 2009. 
A. Water year 2007
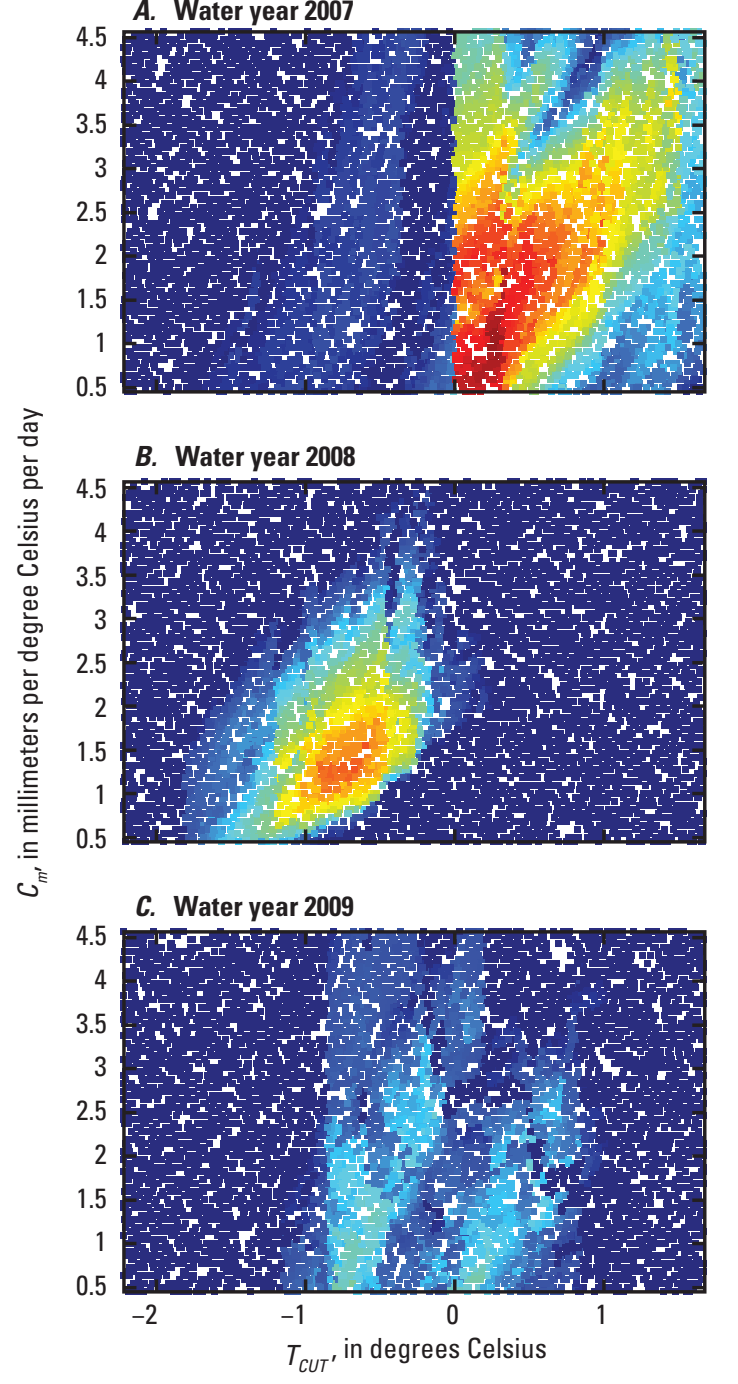

EXPLANATION

$\left[T_{\text {cut }}\right.$, snowmelt cutoff temperature: $C_{m}$, snowmelt rate coefficient]

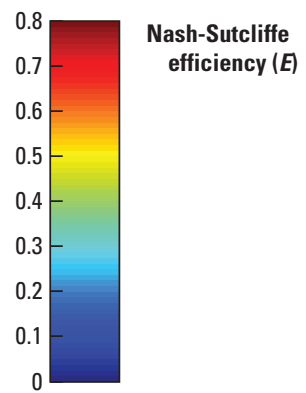

Figure 12. Nash-Sutcliffe efficiency of runoff for snowmelt calibration-parameter space for $A$, water year (WY) 2007, B, WY 2008, and C, WY 2009.

\section{Runoff and Depth-to-Water-Table Calibration}

Using the equivalent liquid-precipitation record generated by the snowmelt calibration, TOPMODEL was calibrated to observed runoff and depth to water table using 100,000 Monte-Carlo model runs evaluated with a combined multipleobjective function. The combined multiple-objective function contained terms representing the evaluation of goodness-of-fit of runoff and depth to water table. TOPMODEL parameters were assigned randomly from a uniform distribution within a range of values (table 4). Parameter ranges were based on values from previous studies and initial, experimental model runs.

Table 4. TOPMODEL parameter-calibration ranges.

\begin{tabular}{llc}
\hline \multicolumn{1}{c}{ Model parameter } & \multicolumn{1}{c}{ Units } & Calibration range \\
\hline Scaling parameter $(m)$ & millimeters & $11-40$ \\
Conductivity multiplier & multiplier & $1.05-100$ \\
Percent macropore flow & decimal percent & $.01-.6$ \\
Depth of root zone & meters & $.2-1.5$ \\
Lake delay & unitless & $1-3$ \\
\hline
\end{tabular}

\section{Runoff Objective Function}

The goodness-of-fit of simulated runoff was evaluated by comparison to observed runoff at USGS streamgage 0131199050 using the Nash-Sutcliffe efficiency of the natural logarithm of runoff. The Nash-Sutcliffe efficiency can range from negative infinity to 1 ; where the computed value of the Nash-Sutcliffe efficiency was negative ( $E$ values less than zero indicate that the average observed value would be a better predictor than the simulated values), the value of the runoff objective function was set to zero:

$$
\operatorname{Obj}_{Q}=\operatorname{maximum}(E(\ln [Q]), 0)=\operatorname{maximum}\left(1-\frac{\sum_{i=1}^{N}\left(\ln \left(Q o_{i}\right)-\ln \left(Q s_{i}\right)\right)^{2}}{\sum_{i=1}^{N}\left(\ln \left(Q o_{i}\right)-\ln (\overline{Q o})\right)^{2}}, 0\right)
$$

where

$$
\begin{aligned}
O b j_{Q} & \text { is the runoff objective function, and } \\
\ln [Q] & \text { is the natural logarithm of runoff. }
\end{aligned}
$$

The logarithm of runoff was used to balance the emphasis on the range of flows for the main calibration. The untransformed runoff was used in the snowmelt calibration because the larger flows were of most interest for accurate calibration of snowmelt events, but accurate reproduction of the full range of flows was considered important in the main calibration. 


\section{Depth-to-Water-Table Objective Functions}

The saturation deficit predicted by TOPMODEL was incorporated into the calibration by conversion to a measure of local depth to water table and comparison to observed values from depth-to-water-table measurements made in Sixmile Wetland (fig. 3). Depth to water table was computed first by converting the basin-average saturation deficit, $\bar{S}$, to a local saturation deficit, $S_{x}$, using equation 3 , which offsets the saturation deficit by a factor related to model parameter $\mathrm{m}$ and the difference between the watershed-average TWI and the local TWI. The TWI in Sixmile Wetland near the observation locations was approximately $11.04 \ln (\mathrm{m})$; the watershed average TWI for the study area was $6.86 \ln (\mathrm{m})$. A local depth to water table then was computed:

$$
z_{x}=\frac{S_{x}}{n_{\text {drain }}}
$$

where

$$
\begin{gathered}
z_{x} \quad \begin{array}{l}
\text { is the local depth to water table, in } \\
\text { millimeters; }
\end{array} \\
S_{x} \quad \text { is the local saturation deficit, in millimeters; } \\
\quad \text { and } \\
n_{\text {drain }} \quad \text { is the readily drained soil porosity. }
\end{gathered}
$$

The modeled depth to water table was compared to two components of observed values: (1) absolute depth to water table and (2) relative depth-to-water-table fluctuations. While depth-to-water-table measurements were available in only one location in the study area, providing limited spatial information, their use provides a reference point within the study area to constrain simulated saturation-deficit values. Additionally, because the location of the groundwater measurements is in a wetland area where methylation and transport of $\mathrm{Hg}$ to the stream is believed to be important, this location is believed to be especially valuable when using TOPMODEL output calibrated to depth to water table to develop approaches for modeling $\mathrm{Hg}$, a goal of the overall NAWQA Hg study.

\section{Absolute Depth to Water Table}

The simulated absolute depth to water table was compared to the tape-down measurements. The measurements were made in three groups: May 5 and 6; May 19 and 20, and August 13, 2009. For purposes of evaluation, values from consecutive days were combined; the median observed depth to water table for a group was compared to the mean of the simulated depth to water table for the group (a 1- or 2-day period). The combined depth-to-water-table value was evaluated by normalizing the RMSE and subtracting from one. Similar to $E$, this value can range from negative infinity to 1 ; where this value was negative, the objective function was set to zero:

$$
O \operatorname{Obj}_{D T W}=\operatorname{maximum}\left(1-\frac{R M S E(D T W T D)}{\overline{D T W T D_{o}}}, 0\right)
$$

where

$O b j_{D T W T D}$ is the absolute depth-to-water-table objective function,

$R M S E(D T W T D)$ is the root mean squared error of the combined observed and simulated absolute depth to water table, and $\overline{D T W T D}_{o}$ is the mean of the combined observed depth to water table.

\section{Relative Depth-to-Water-Table Fluctuations}

The relative depth-to-water-table fluctuations was evaluated using the Pearson correlation coefficient $(r)$ of the observed and simulated depth to water table for the period of observed depth to water table described previously in this report. This approach tests the ability of the model to simulate the variation of depth to water table over time without constraining it to an absolute value; Seibert and McDonnell (2002) applied this method to depth to water table in the calibration of a three-box conceptual model to runoff, depth to water table, and additional fuzzy measures, including measures of new water and reservoir volume. The simulated and observed depth to water table for the period of the piezometer measurements was converted to a depthabove-average water table. The correlation of the daily time series of water levels in each of the seven piezometers with the simulated depth to water table was computed, and the relative depth-to-water-table fluctuation objective function was computed as the mean of the seven correlation coefficients:

$$
O b j_{D T W T S}=\frac{\sum_{j=1}^{M} r_{j}}{M}
$$

where

$$
\begin{aligned}
& O b j_{D T W T S} \quad \text { is the relative depth-to-water-table objective } \\
& \text { function, } \\
& r_{j} \quad \text { is Pearson's correlation coefficient for } \\
& \text { piezometer } j \text {, and } \\
& M \quad \text { is the number of piezometers. }
\end{aligned}
$$

The correlation coefficient can range from -1 to 1 ; in this case, all simulated values were positively correlated with the observed values.

\section{Combined Multiple-Objective Function}

The three objective functions (runoff, absolute depth to water table, and relative groundwater table level) were combined into a single objective function using a weighted geometric mean. Runoff was weighted equally to depth to water table; within the depth to water table, the absolute depth to water table was weighted equally to relative depth to water table, as follows: 


$$
O b j_{\text {comb }}=O b j_{Q}^{1 / 2} * O b j_{D T W T D}^{1 / 4} * O b j_{D T W T S}^{1 / 4}
$$

where

$$
\mathrm{Obj}_{\text {comb }} \text { is the weighted combined multiple-objective }
$$
function.

The combined-objective function then will have a value between zero and 1.

\section{Generalized Sensitivity Analysis}

A generalized sensitivity analysis, following the form proposed in Spear and Hornberger (1980) and Hornberger and Spear (1981), was performed on the set of 100,000 maincalibration runs. The cumulative-distribution function (cdf) for each of the five model-calibration parameters (fig. 13) was compared for 'behavioral' runs (the highest 10 percent for the combined-objective function) and 'nonbehavioral' runs (the lowest 90 percent for the combined-objective function). If the model (or objective function evaluating the model) is sensitive to a calibration parameter, the cdf for the behavioral runs will be different from the cdf for the nonbehavioral runs. The Kolmogorov-Smirnov $d$ (KSD) statistic was used as a simple measure to quantify the difference among distributions (Spear and Hornberger, 1980); higher values of KSD represent larger differences among cdfs. The results of the sensitivity analysis showed that the most sensitive parameter is the scaling parameter $m$ (KSD 0.69). The parameter conductivity multiplier conmult showed moderate sensitivity (KSD 0.32); the root zone depth zroot and lake delay factor rip_decay showed some sensitivity (KSD 0.18 and 0.13 , respectively). The percent macropore flow parameter showed little sensitivity (KSD 0.01). The results of the generalized sensitivity analysis should be considered somewhat subjective, as they depend on the objective function used and the cutoff between behavioral and non-behavioral runs; co-dependence of multiple parameters sometimes can be exhibited as a lack of sensitivity.

Dotty plots of the model-calibration parameters versus the combined multiple-objective function and each of the component-objective functions (fig. 14) reveal different patterns of interaction among model parameters and each of the component-objective functions. Dotty plots represent a method to collapse the multi-dimensional parameter space into single parameter dimensions; each point in the plot represents one model run and shows the value of one parameter versus a measure of the model outcome. While dotty plots cannot show the complex interactions between multiple parameters, they can help illustrate the response of the model. Some of the objective measures are not sensitive to certain individual model parameters; for example, $\mathrm{Obj}_{Q}$ shows little, if any, response to the conductivity multiplier parameter, and $O b j_{D T W T D}$ shows little response to the lake delay factor, with values reaching the maximum and minimum of the objective across the range of the model-parameter value. These model parameters do, however, affect other objective functions, with maximum values of the objective function being attained by specific ranges of the model parameter. While $\mathrm{Obj}_{Q}$ shows little response to the conductivity-multiplier parameter, higher values of $O b j_{D T W T D}$ occur for higher values of this parameter. The parameter that shows the most specific effect of all of the
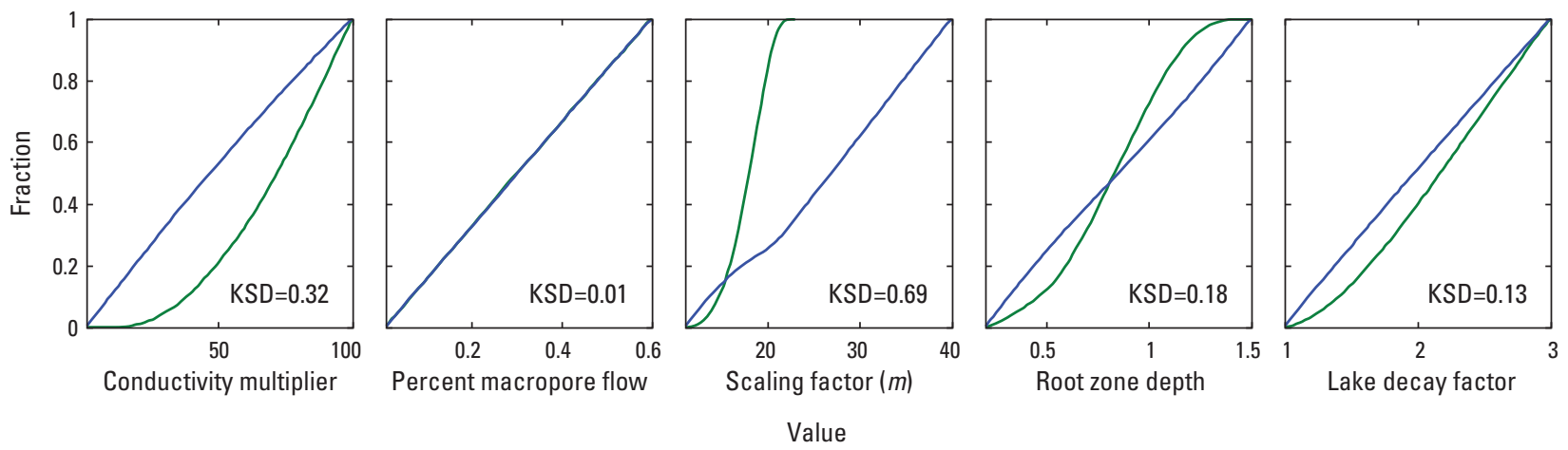

EXPLANATION

[KSD, Kolmogorov-Smirnov d statistic; $\mathrm{Obj}_{\text {comb }^{\prime}}$ combined multiple-objective function]

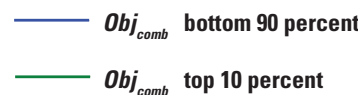

Figure 13. Generalized sensitivity analysis cumulative-probability distributions for TOPMODEL calibration parameters with Kolmogorov-Smirnov $d$ statistic value. 


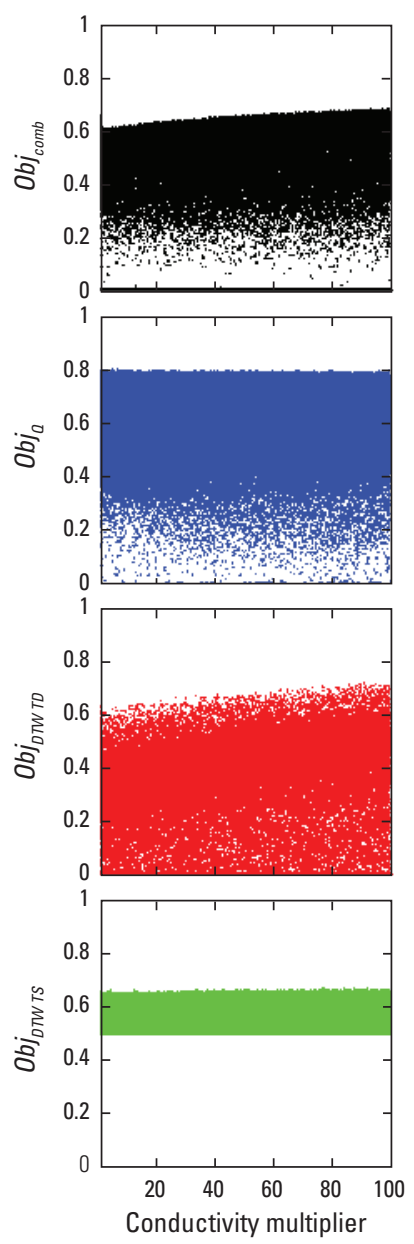

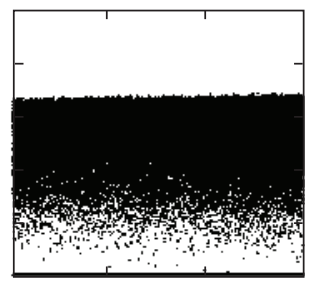
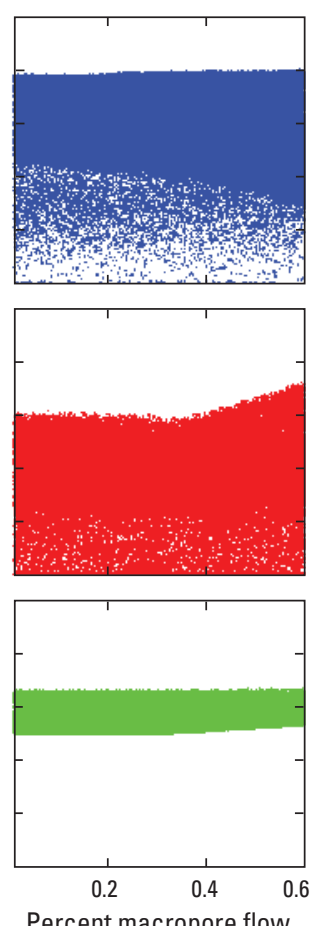
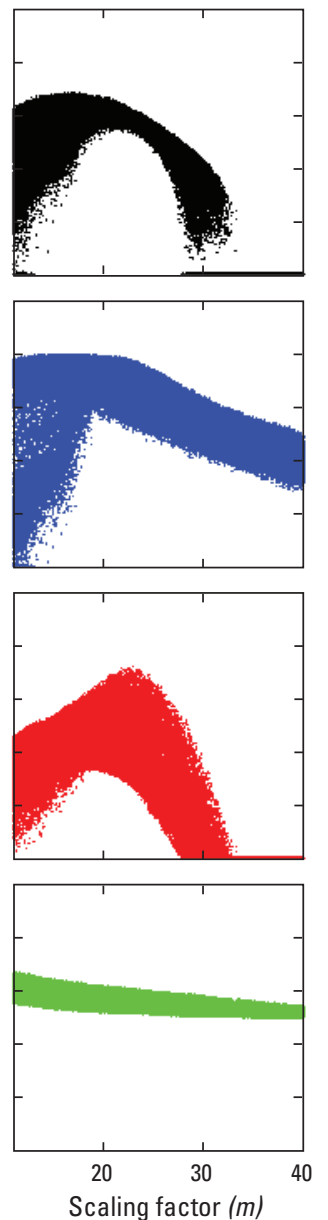

EXPLANATION
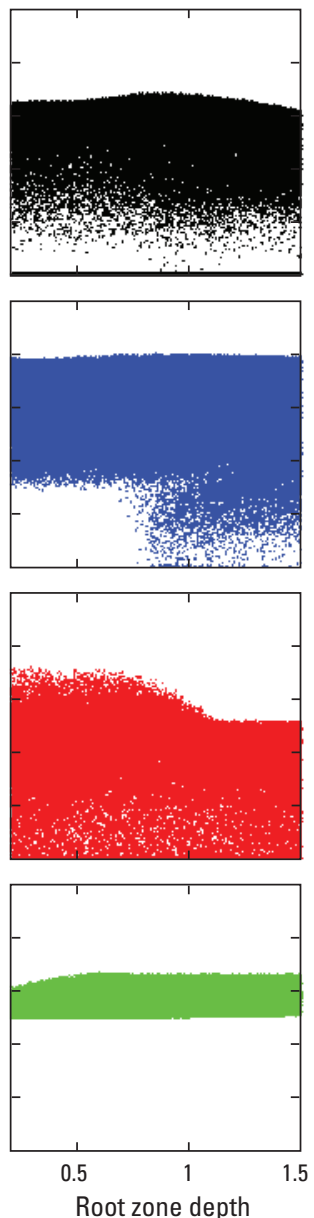
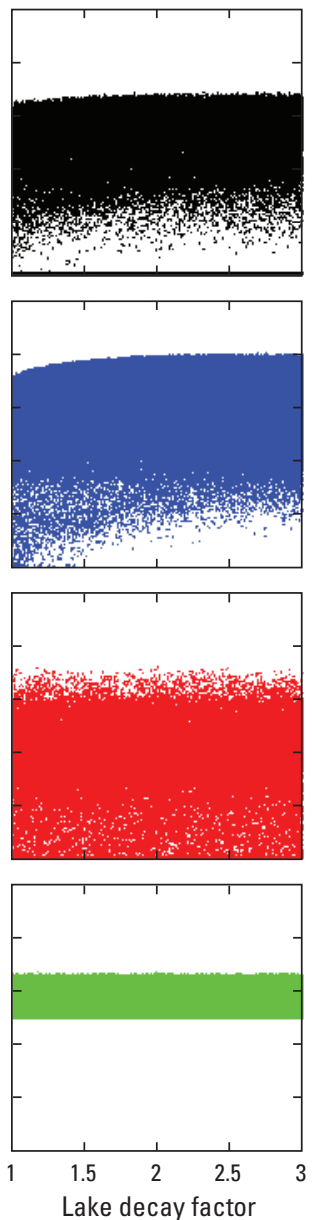

\footnotetext{
$\boldsymbol{O b j}_{\text {comb }} \square$ Combined multiple-objective function

$\mathbf{O b j}_{\boldsymbol{a}} \square$ Runoff objective function

$\boldsymbol{O b j}_{\text {DTw TD }} \square$ Absolute depth-to-water-table objective function

$\boldsymbol{O b j}_{\text {DTw Ts }}$ Relative time series depth-to-water-table objective function
}

Figure 14. Dotty plots of combined multiple-objective function and component-objective functions.

objective functions - the scaling factor $m$ - shows a slightly different response shape in each of the component-objective functions; the shape of the multiple-objective function scatter plot balances these component objectives when combined.

\section{TOPMODEL-Simulation Results}

The runoff and saturation deficits simulated by TOPMODEL are shown in figures 15-17. In the following sections, the results are described qualitatively, graphically, and statistically. Two main aspects of the results of TOPMODEL simulations are discussed:

(1) the single TOPMODEL run with the highest value of the combined-objective function, referred to hereafter as the 'best run,' is compared to observed values, and (2) the variability within the set of model runs and the uncertainty of the model predictions is assessed using prediction intervals.

A prediction interval, as used in this study, is a group of simulated values for a defined class of Monte-Carlo model runs. In this case, the classes are defined based on percentiles of the combined-objective function. Because the model output is highly dependent on the selection of calibrationparameter ranges and objective function(s), formal statistical probabilities are not assigned, as in Bayesian uncertainty analysis or more formal applications of the Generalized Likelihood Uncertainty Estimate (GLUE) as described in Beven and Binley (1992). The prediction-interval classes are 

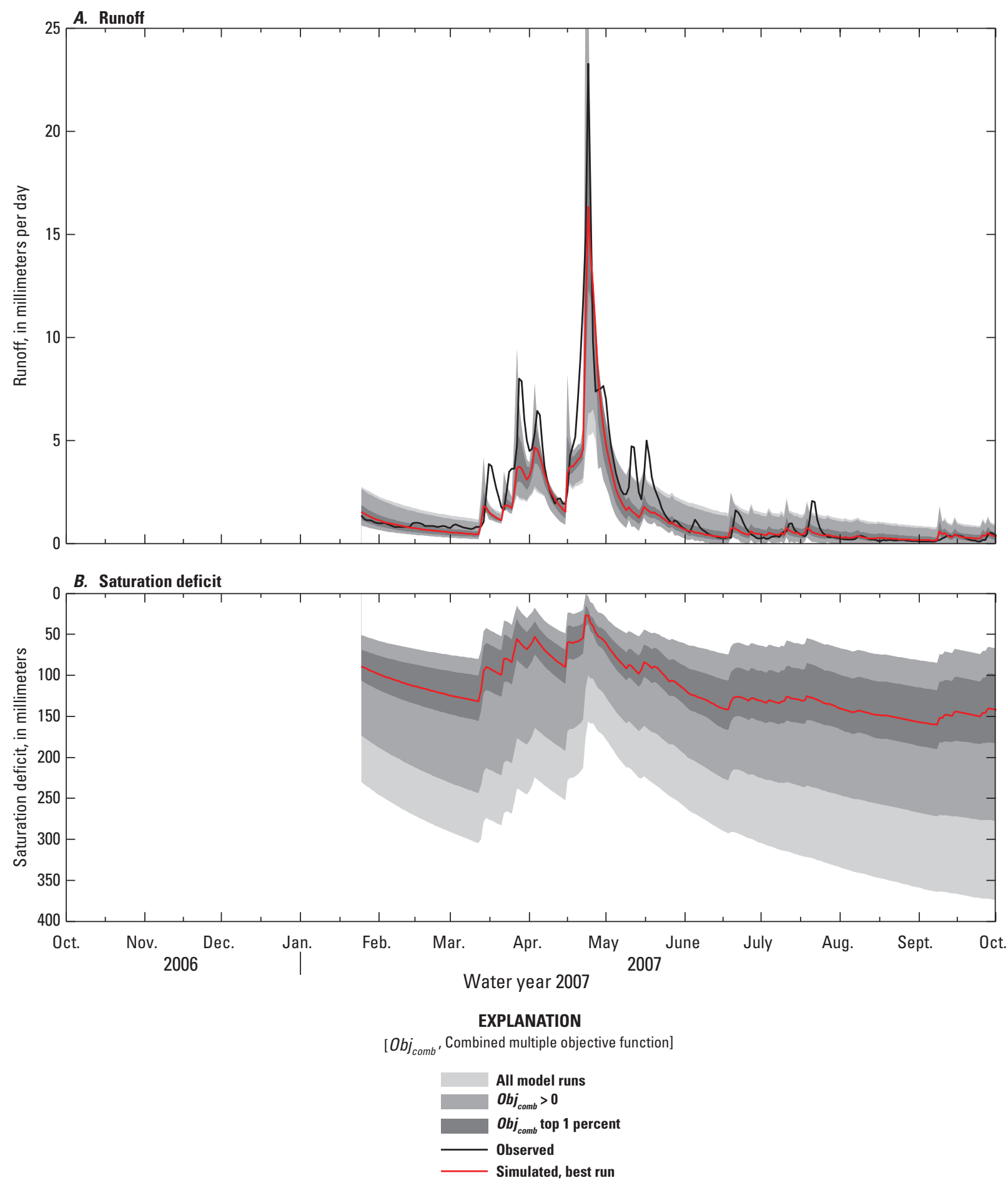

Figrue 15. Simulated runoff and watershed-average saturation deficit, best run for the modeling period and prediction intervals, Fishing Brook at County Line Flow near Newcomb, New York, water year 2007. 

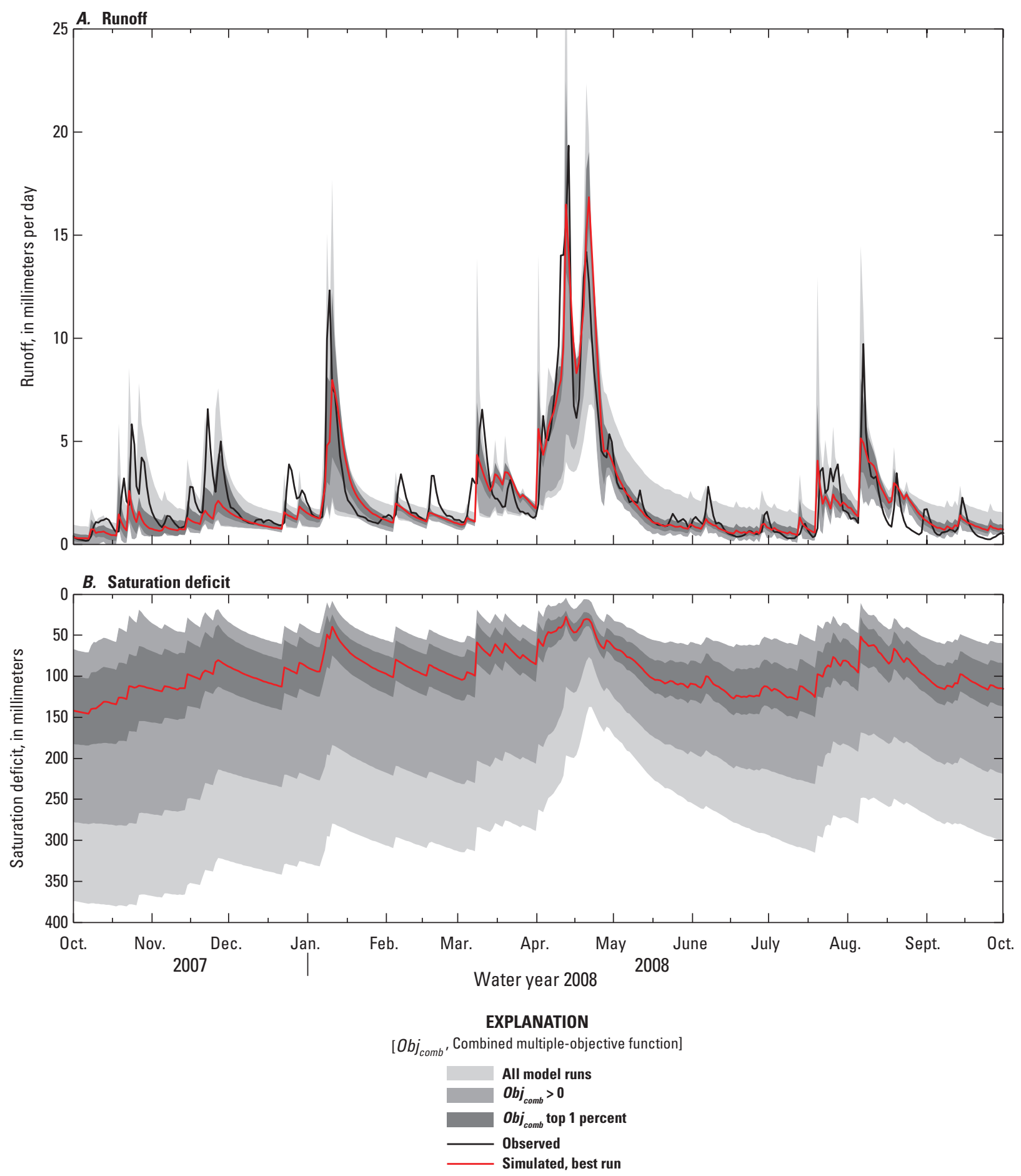

Figrue 16. Simulated runoff and watershed-average saturation deficit, best run for the modeling period and prediction intervals, Fishing Brook at County Line Flow near Newcomb, New York, water year 2008. 

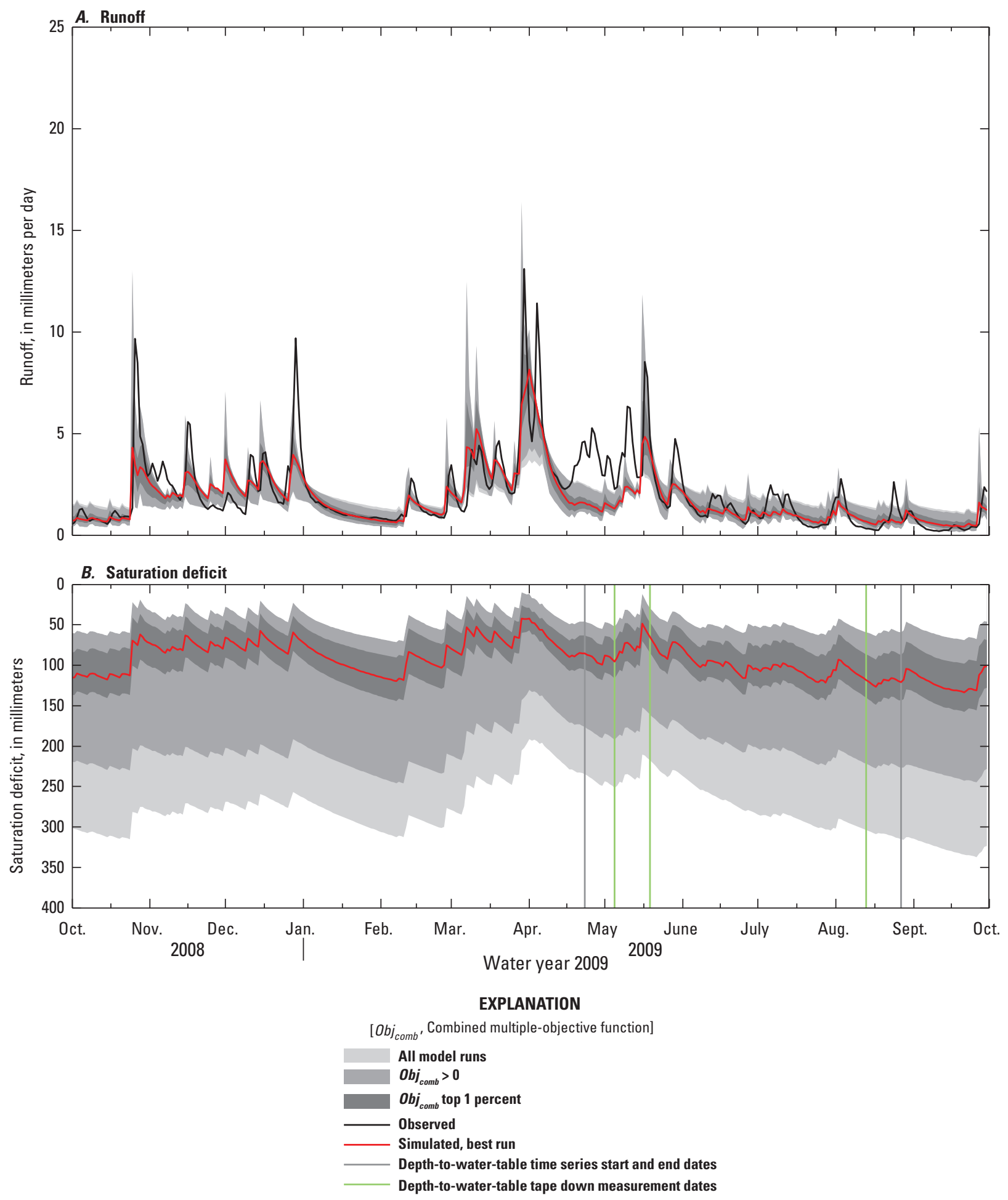

Figrue 17. Simulated runoff and watershed-average saturation deficit, best run for the modeling period and prediction intervals, Fishing Brook at County Line Flow near Newcomb, New York, water year 2009. 
defined starting with the best run; followed by those runs with the highest 0.1 percent of combined-objective values (referred to as ' $O b j_{\text {comb }}$ top 0.1 percent'), the highest 1 percent of runs (' $O b j_{\text {comb }}$ top 1 percent'), and the highest 10 percent of runs ('Obj ${ }_{\text {comb }}$ top 10 percent'); then all 64,746 runs with combined objective greater than zero (' $O b j_{\text {comb }}>0$ '); and finally, the full range of 100,000 model runs ('all runs'). Simulated values within each group are compared; variability of model output also is described by the width of the prediction interval, or the difference between the maximum and minimum simulated values within a group at a time step. Predictioninterval widths (figs. 15-17) for three of the classes, as shown by shaded areas, vary over time with the general basinsaturation condition.

The calibrated model-parameter values are listed in table 5 and are shown in figure 18 by prediction-interval class. The specificity of the calibration parameters generally reflects the results of the sensitivity analysis; the most sensitive parameters have smaller ranges and standard deviations in the highest interval classes compared to their overall distribution. For example, the ratio of the standard deviation of parameter values for the 1 percent class as compared to that of all runs is 0.17 for the scaling parameter $m$, and 0.91 for percent macropore flow (table 5).

The maximum value of the combined multipleobjective function achieved in the 100,000 model runs was 0.678 (table 6). Component objective-function values corresponding to the model run with the highest combinedobjective values were in the 89th percentile or higher of their individual objective-function value ranges. The maximum values of each of the component-objective functions also are shown in table 6 , along with the values of the other component-objective functions for that model run; they illustrate the specificity of each of the objective functions, and that calibration of TOPMODEL to runoff alone will not necessarily produce accurate predictions of depth to water table.

Table 5. Calibrated-model parameter values, best run, and prediction-interval classes.

$\left[\mathrm{Obj}_{\text {comb }}\right.$, weighted combined multiple objective function; \%, percent; >, greater than]

\begin{tabular}{|c|c|c|c|c|c|c|}
\hline & & $\begin{array}{l}\text { Conductivity } \\
\text { multiplier }\end{array}$ & $\begin{array}{l}\text { Percent } \\
\text { macropore } \\
\text { flow }\end{array}$ & $\begin{array}{c}\text { Scaling } \\
\text { parameter } m, \\
\text { millimeters }\end{array}$ & $\begin{array}{l}\text { Depth of } \\
\text { root zone, } \\
\text { meters }\end{array}$ & $\begin{array}{l}\text { Lake delay, } \\
\text { days }^{-1}\end{array}$ \\
\hline \multirow{2}{*}{\multicolumn{2}{|c|}{$\begin{array}{l}\text { Calibration range } \\
\text { Value, best run }\end{array}$}} & 1.05 to 100 & 0.01 to 0.6 & 11 to 40 & 0.2 to 1.5 & 1 to 3 \\
\hline & & 99.117 & 0.509 & 16.904 & 0.921 & 2.315 \\
\hline \multirow{5}{*}{ 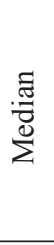 } & $O b j_{\text {comb }}$ top $0.1 \%$ & 92.917 & .512 & 16.821 & .886 & 2.410 \\
\hline & $O b j_{\text {comb }}$ top $1 \%$ & 87.308 & .403 & 17.105 & .878 & 2.384 \\
\hline & $O b j_{\text {comb }}$ top $10 \%$ & 72.296 & .302 & 18.097 & .836 & 2.175 \\
\hline & $O b j_{c o m b}>0$ & 49.496 & .313 & 20.385 & .840 & 2.005 \\
\hline & All runs & 50.461 & .305 & 25.483 & .851 & 2.003 \\
\hline \multirow{7}{*}{ 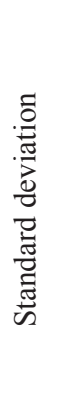 } & $O b j_{\text {comb }}$ top $0.1 \%$ & 4.809 & .100 & .957 & .079 & .375 \\
\hline & $O b j_{\text {comb }}$ top $1 \%$ & 11.029 & .154 & 1.429 & .119 & .430 \\
\hline & $O b j_{\text {comb }}$ top $10 \%$ & 20.874 & .170 & 2.178 & .261 & .516 \\
\hline & $O b j_{\text {comb }}>0$ & 28.495 & .172 & 5.473 & .374 & .576 \\
\hline & All runs & 28.457 & .170 & 8.364 & .376 & .576 \\
\hline & $\begin{array}{l}\text { Ratio, } O b j_{\text {comb }} \text { top } \\
0.1 \% \text { to all runs }\end{array}$ & .17 & .59 & .11 & .21 & .65 \\
\hline & $\begin{array}{l}\text { Ratio, } O b j_{\text {comb }} \text { top } 1 \% \\
\text { to all runs }\end{array}$ & .39 & .91 & .17 & .32 & .75 \\
\hline
\end{tabular}



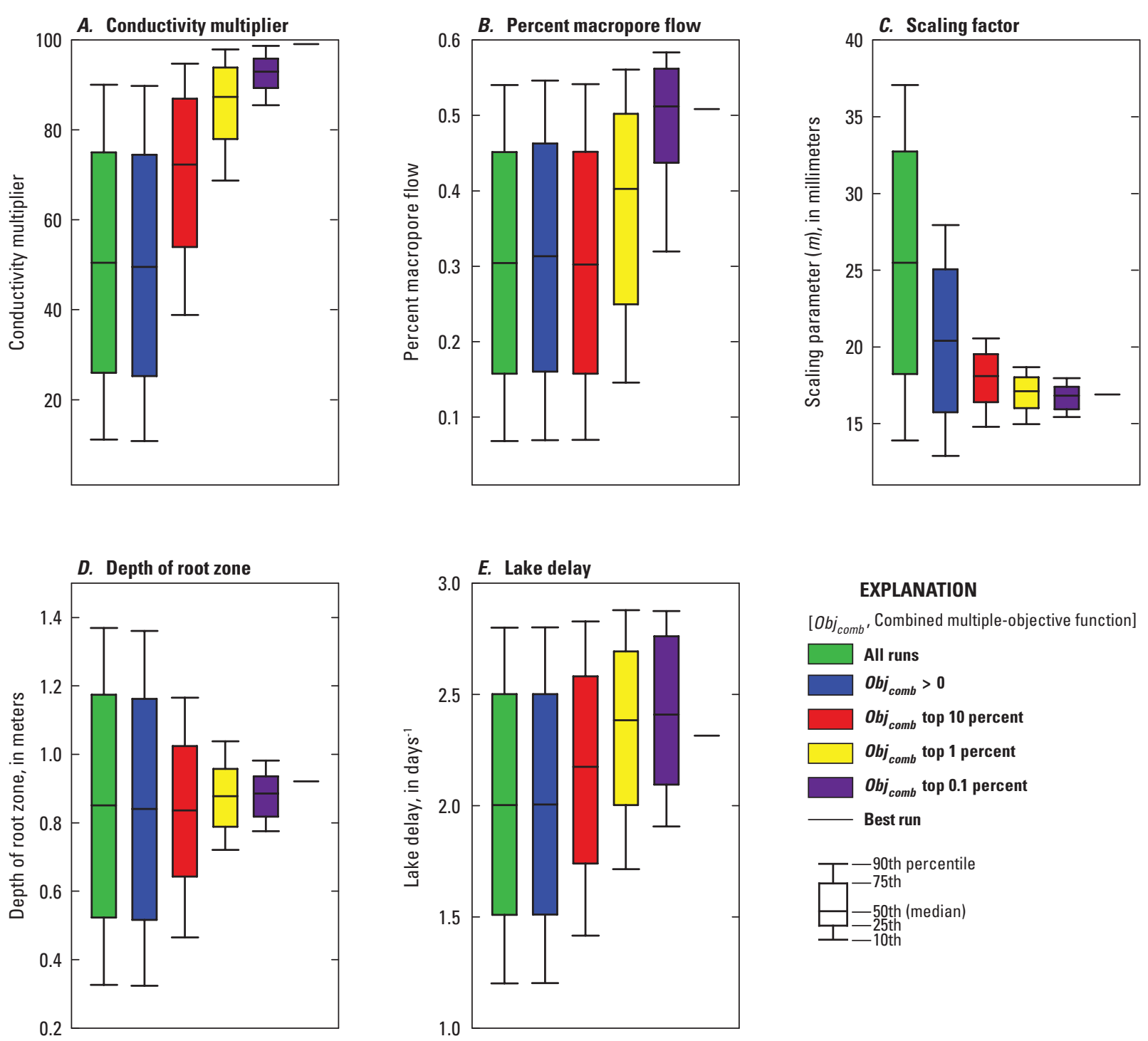

\section{EXPLANATION}

$\left[\mathrm{Obj}_{\text {comb }}\right.$, Combined multiple-objective function] $\square$ All runs

Dobj ${ }_{\text {comb }}>0$

$\mathrm{Obj}_{\text {comb }}$ top 10 percent

$\square O^{-} b_{\text {comb }}$ top 1 percent

$O \mathrm{Obj}_{\text {comb }}$ top 0.1 percent

Best run

\begin{tabular}{l}
$\square$-90th percentile \\
-75th \\
-50th (median) \\
$\square=25 \mathrm{th}$ \\
\hline -10th
\end{tabular}

Figure 18. Boxplots of calibration-parameter values, by prediction-interval class. 
Table 6. Objective-function values for selected model runs and ranges.

$\left[O b j_{\text {comb }}\right.$, weighted combined multiple objective function; $O b j_{Q}$, runoff objective function; $O b j_{D T W T D}$, absolute depth-to-water-table objective function; $O b j_{D T W}$, relative time series depth-to-water-table objective function]

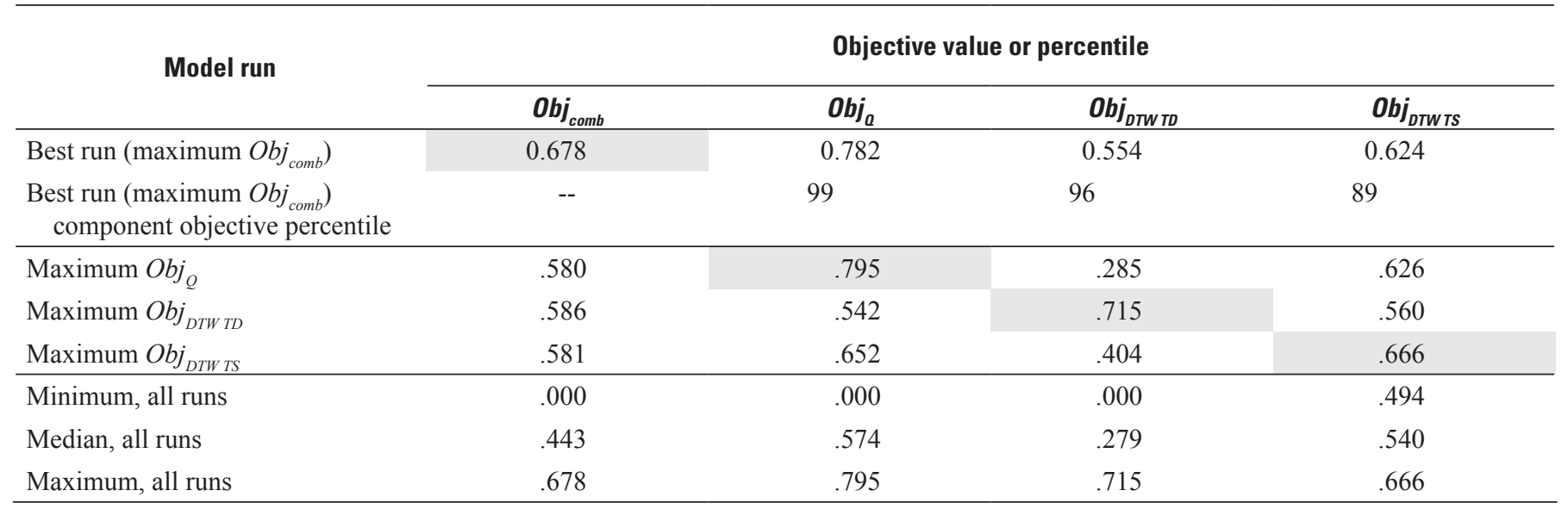

\section{Runoff}

Plots of the simulated runoff for the best run show that the model captures the general shape and trends of the observed runoff fairly well (fig. 19); the Nash-Sutcliffe efficiency of runoff is 0.738 , and 0.782 for the natural $\log$ of runoff (table 7). The residuals of the simulated and observed runoff for the best run are shown by WY in figure 20. The model generally underpredicts the peak value of runoff events (seen as negative residual peaks in fig. 20); the relative magnitude of this error generally is greater for small to moderate events, similar to TOPMODEL simulations for the same Fishing Brook Watershed as shown in Schelker and others (2011). A scatter plot of simulated and observed daily runoff (fig. 21) shows that flows generally fall along the 1:1 line of correspondence, with a Pearson correlation coefficient of 0.868 (table 7); however, at low flows, residuals tend to be positive (overestimation by the model, plotting above the 1:1 line), and at mid to high flows, residuals tend to be negative (underestimation by the model, plotting below the 1:1 line). The largest residuals, both positive and negative, occur at the higher simulated flows; residuals are small for low flows (fig. 22). These overpredictions and underpredictions also are apparent in the basic statistics describing runoff (table 8) and in the flow-duration curves for the modeling period (fig. 23).

Overall, the model underpredicts the total volume of runoff by approximately 14 percent (fig. 24), with an average bias of $-0.287 \mathrm{~mm} / \mathrm{d}$ (table 7 ). Total simulated evapotranspiration for the modeling period was $1,463 \mathrm{~mm}$, or 46 percent of total precipitation. Murdoch and others (1987), by comparison, observed evapotranspiration rates of approximately 40 percent in two watersheds approximately $50 \mathrm{~km}$ from the Fishing Brook study area.

Most of the 100,000 Monte-Carlo model runs underpredicted total runoff (the range of simulated cumulative runoff as shown by the shaded area in fig. 24); interestingly, the model run with the highest combined multiple-objective function is close to the minimum simulated cumulative runoff (or largest underprediction) for all of the model runs. The majority ( 89 percent) of the total underprediction for the best run occurred during three events (dark blue in fig. 24) comprising 20 percent of the modeling period: during snowmelt 2007, the mid-winter melt events during October-December 2007, and a post-snowmelt event in 2009. These three events contained negative residuals that were not balanced by the occurrence of any significant positive residuals, unlike many other events. The average underprediction during these events was $1.25 \mathrm{~mm} / \mathrm{d}$, compared to $0.04 \mathrm{~mm} / \mathrm{d}$ during the remainder of the modeling period; without these three events, total model underprediction is approximately 1.5 percent. These three underprediction events could represent an artifact of the separate snowmelt calibration or of the objective function used. 


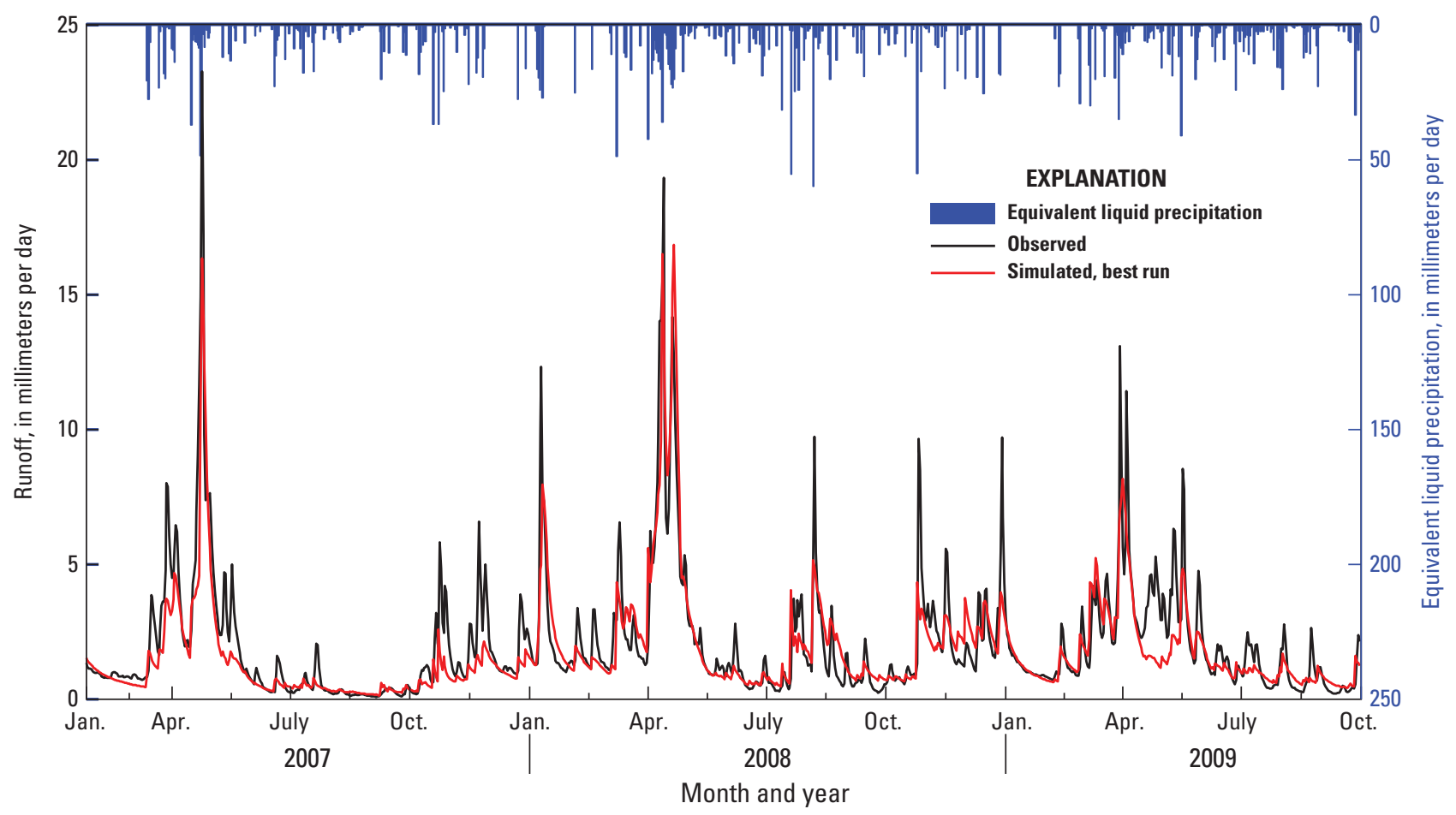

Figure 19. Simulated runoff, observed runoff, and equivalent liquid precipitation for Fishing Brook at County Line Flow near Newcomb, New York, best run for the modeling period.

Table 7. Descriptive statistics for simulated runoff, best run, and all model runs during the model period for Fishing Brook at County Line Flow near Newcomb, New York.

$[E$, Nash-Sutcliffe coefficient of model-fit efficiency; $E(\ln )$, Nash-Sutcliffe coefficient evaluated for the natural logarithm of a quantity; $r$, Pearson's correlation coefficient; RMSE, root mean squared error; $\mathrm{mm} / \mathrm{d}$, millimeter per day; MAE, mean absolute error]

\begin{tabular}{lrrrrrr}
\hline & $\boldsymbol{E}$ & $\boldsymbol{E}(\mathbf{l n})$ & $\boldsymbol{r}$ & RMSE, $\mathbf{m m} / \mathbf{d}$ & Bias, mm/d & MAE, mm/d \\
\hline Best run & 0.738 & 0.782 & 0.868 & 1.224 & -0.287 & 0.696 \\
Minimum, all runs & .349 & -.135 & .648 & 1.149 & -.323 & .683 \\
Median, all runs & .616 & .574 & .803 & 1.483 & -.226 & .855 \\
Maximum, all runs & .769 & .795 & .886 & 1.931 & .045 & 1.154 \\
\hline
\end{tabular}



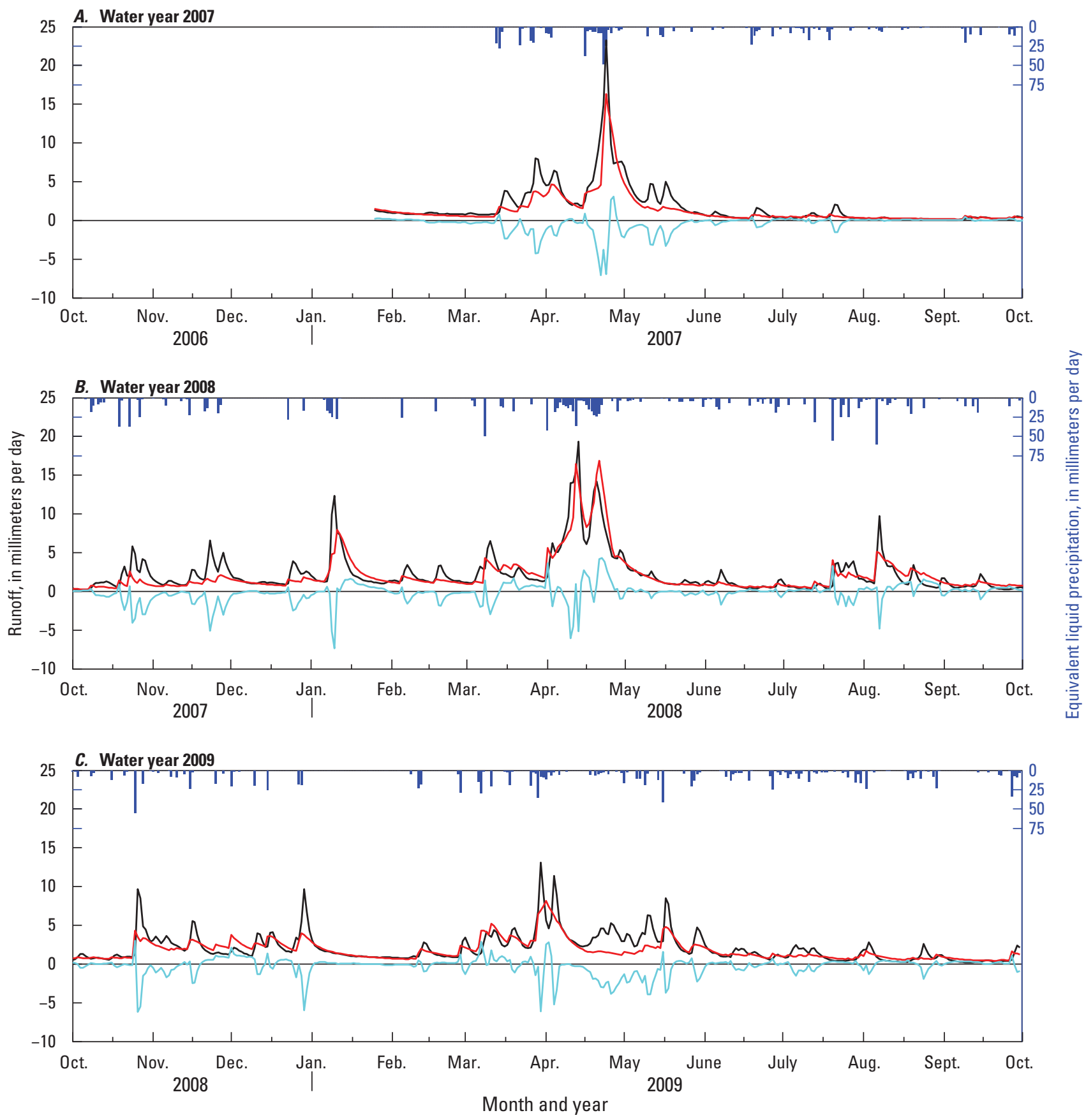

EXPLANATION

Equivalent liquid precipitation

Observed runoff

Simulated runoff, best run

Residual, best run

Figure 20. Simulated runoff, observed runoff, residuals, and equivalent liquid precipitation for Fishing Brook at County Line Flow near Newcomb, New York, best run for the modeling period for $A$, water year (WY) 2007, B, WY 2008, and $C$, WY 2009. 


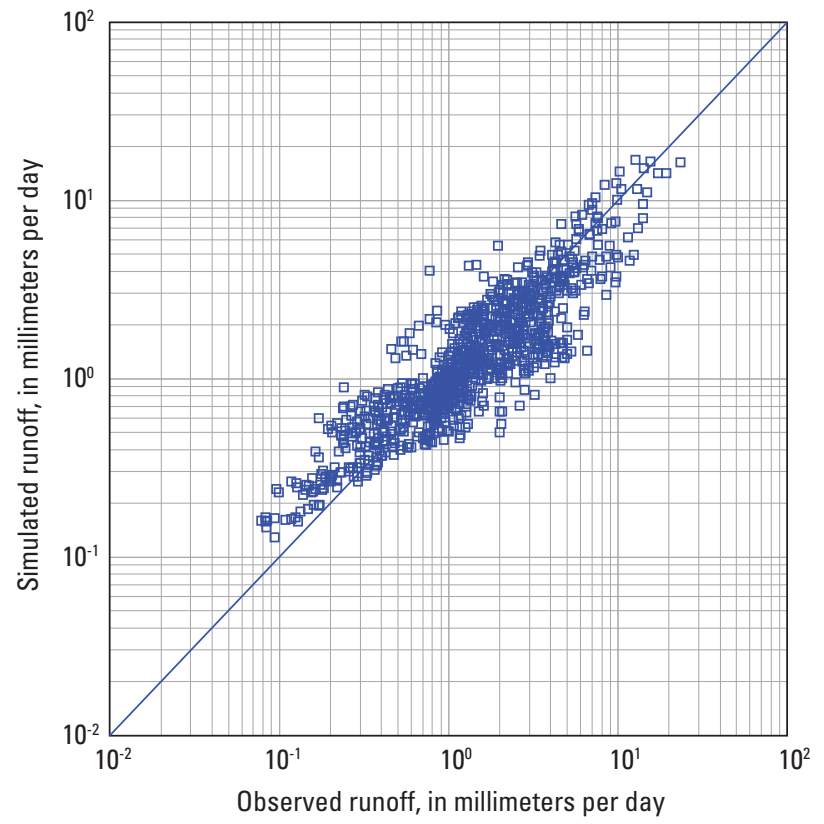

Figure 21. Scatter plot of observed runoff and simulated runoff for Fishing Brook at County Line Flow near Newcomb, New York, best run for the modeling period. The blue line represents a 1:1 correspondence of simulated and observed runoff.

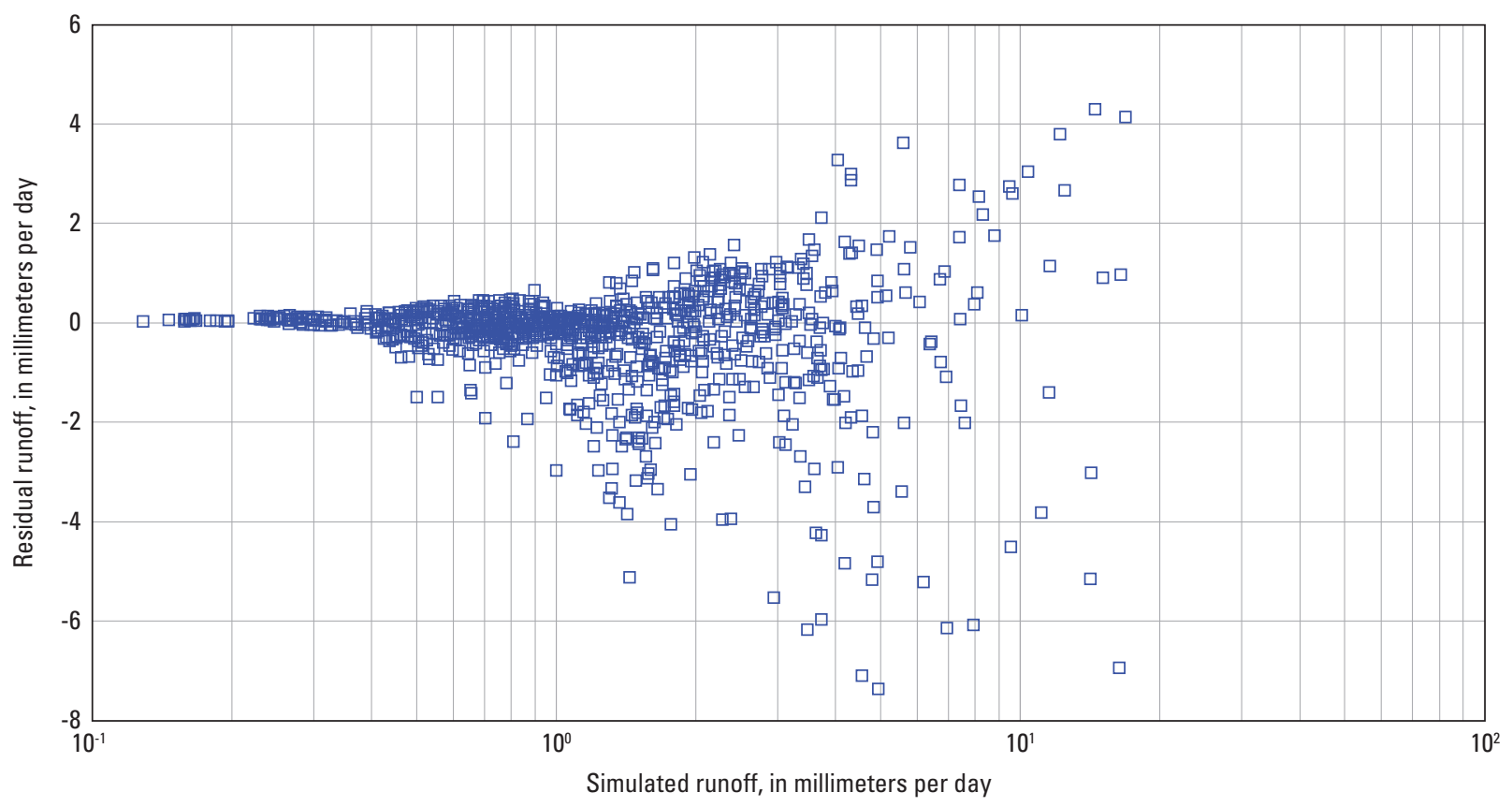

Figure 22. Scatter plot of simulated runoff and residuals for Fishing Brook at County Line Flow near Newcomb, New York, best run for the modeling period. 
Table 8. Descriptive statistics for observed and simulated daily mean runoff and best run during the model period for Fishing Brook at County Line Flow near Newcomb, New York.

\begin{tabular}{lccc}
\hline & $\begin{array}{c}\text { Observed runoff, } \\
\text { millimeters per day }\end{array}$ & $\begin{array}{c}\text { Simulated runoff, best run, } \\
\text { millimeters per day }\end{array}$ & $\begin{array}{c}\text { Residual runoff, best run, } \\
\text { millimeters per day }\end{array}$ \\
\hline Minimum & 0.078 & 0.129 & -7.37 \\
Median & 1.27 & 1.17 & -.031 \\
Mean & 2.08 & 1.78 & -.287 \\
Maximum & 23.3 & 16.8 & 4.29 \\
Standard deviation & 2.39 & 2.02 & 1.19 \\
Sum, $1 / 25 / 2007$ to $9 / 30 / 2009$ & 2,043 & 1,761 & -282 \\
\hline
\end{tabular}

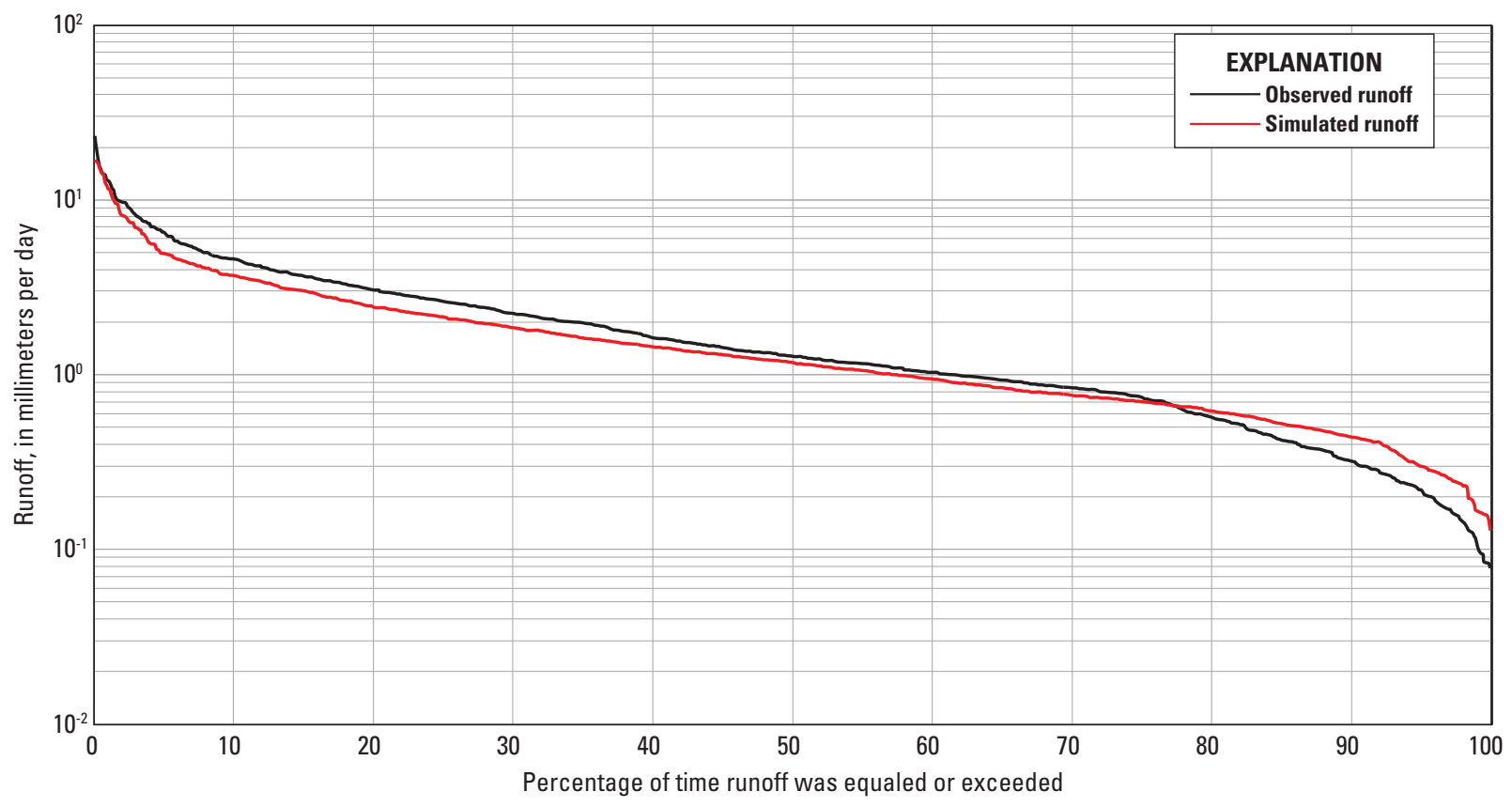

Figure 23. Flow-duration curves of observed and simulated runoff for Fishing Brook at County Line Flow near Newcomb, New York, best run for the modeling period. 

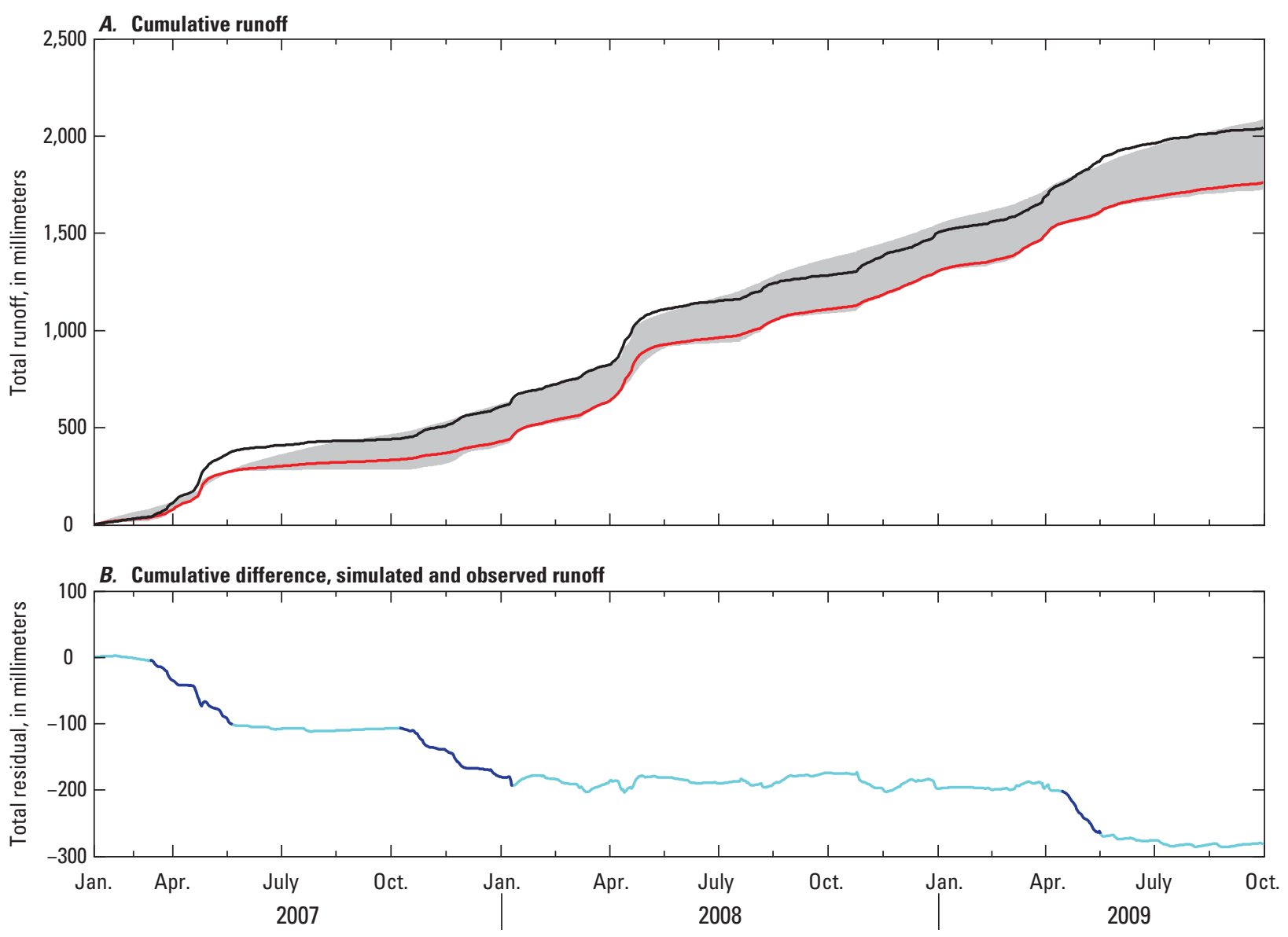

Month and year

\section{EXPLANATION}

\begin{tabular}{ll} 
Range, all model runs \\
Observed \\
Simulated, best run \\
Difference, best and observed \\
\hline Underprediction event
\end{tabular}

Figure 24. $A$, Cumulative simulated and observed runoff, and $B$, cumulative difference, simulated and observed runoff, for Fishing Brook at County Line Flow near Newcomb, New York, best run and range for all model runs for the modeling period. 


\section{Prediction-Interval Uncertainty Analysis}

The forms of the runoff-prediction intervals generally are similar to that of the best model run (figs. 15-17).The best run as determined by the combined-objective function tended to underpredict or "miss" many of the small or moderate, non-snowmelt rainfall-runoff events; comparing the timing of the peaks in the prediction intervals to those of the observed runoff reveals a slight timing offset in many of the summer and fall events. Timing offsets can cause significant decreases in the Nash-Sutcliffe efficiency (McCuen and others, 2006); therefore, the combined-objective function was probably insensitive to these runoff events, as the simulated-runoff peak occurred during a different time step than the observedrunoff peak.

The median width of the prediction intervals for the five classes varied from 0.292 to $1.36 \mathrm{~mm} / \mathrm{d}$ (table 9). The median width of the prediction intervals was smaller than the median simulated runoff for the top three classes of prediction intervals (table 9). The range of simulated-runoff values generally was much larger for larger runoff (for example fig. 25C). Correspondingly, the width of each of the prediction intervals varied with time; prediction-interval widths were $5 \mathrm{~mm} / \mathrm{d}$ or less for almost all time steps and classes (fig. 26); the maximum range in predicted values over all model runs was $27.3 \mathrm{~mm} / \mathrm{d}$, which is approximately equal to the maximum observed runoff during the modeling period.

\section{Depth to Water Table}

Simulated watershed-average saturation deficits for the best run ranged from 26.7 to $161 \mathrm{~mm}$, with a median value of $99.3 \mathrm{~mm}$ and a range of $134 \mathrm{~mm}$ during the modeling period (table 10 and figs. 15-17). The median depth to water table calculated using the watershed-average readily drained soil porosity is $715 \mathrm{~mm}$ for the entire watershed (table 10), with a range of about $1 \mathrm{~m}$ during the modeling period (fig. 27).
Plots of observed and simulated depth to water table (fig. 28) and relative depth-to-water-table fluctuations (fig. 29) show that depth to water table computed from TOPMODEL predicted-saturation deficits fall within the range of observed values. The observed depth to water table follows a generally increasing, or drying, trend over the period of observations; a corresponding overall decrease in runoff also was observed during this period. Both plots show that the slope of TOPMODEL-simulated depth to water table was greater than the observed depth to water table; the model "dries out" more rapidly than indicated by observations.

Goodness-of-fit statistics for absolute depth to water table (left side of table 11) show the RMSE and MAE for the model run with the highest combined-objective value were approximately $90 \mathrm{~mm}$; in comparison, the average observed depth to water table was $205 \mathrm{~mm}$. The median depth-to-watertable bias of all model runs (table 11) was positive (drier than observed), while the best run as chosen by the combined objective had a negative depth-to-water-table bias (wetter than observed).

The relative depth-to-water-table fluctuation component objective - the average Pearson correlation coefficientranged from 0.494 to 0.666 (right side of table 11); this range was narrower than for other component-objective values (table 6). A scatter plot of all observed depth-above-average time series and the simulated depth-above-average time series (fig. 30) has a correlation of 0.59 and generally falls around a 1:1 line.

Saturation deficits and depth to water table calculated for specific TWIs and mapped back to locations in the watershed are offset from the watershed average by a constant proportional to the TWI. The median depth to water table at Sixmile Wetland for the best run was $206 \mathrm{~mm}$ (table 10) and ranged from -316 to $647 \mathrm{~mm}$ (fig. 31); for an example upland area with a TWI of 5 , the median depth to water table was $939 \mathrm{~mm}$. The saturation deficit computed for Sixmile Wetland, the location where depth to water table was observed, is

Table 9. Runoff prediction-interval widths, by class, for Fishing Brook at County Line Flow near Newcomb, New York.

[mm/d, millimeter per day; $O b j_{\text {comb }}$, weighted combined multiple-objective function; \%, percent; >, greater than]

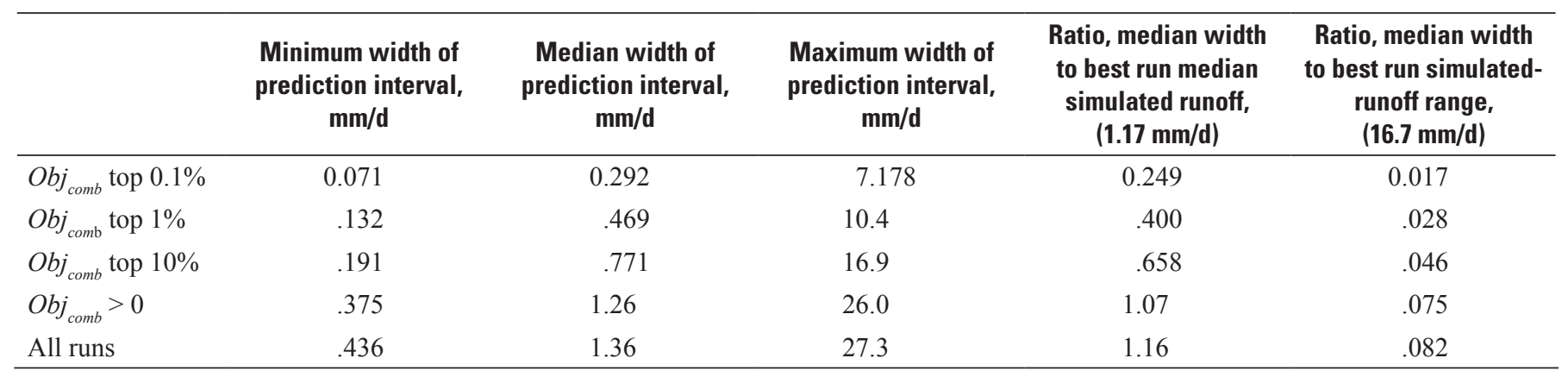




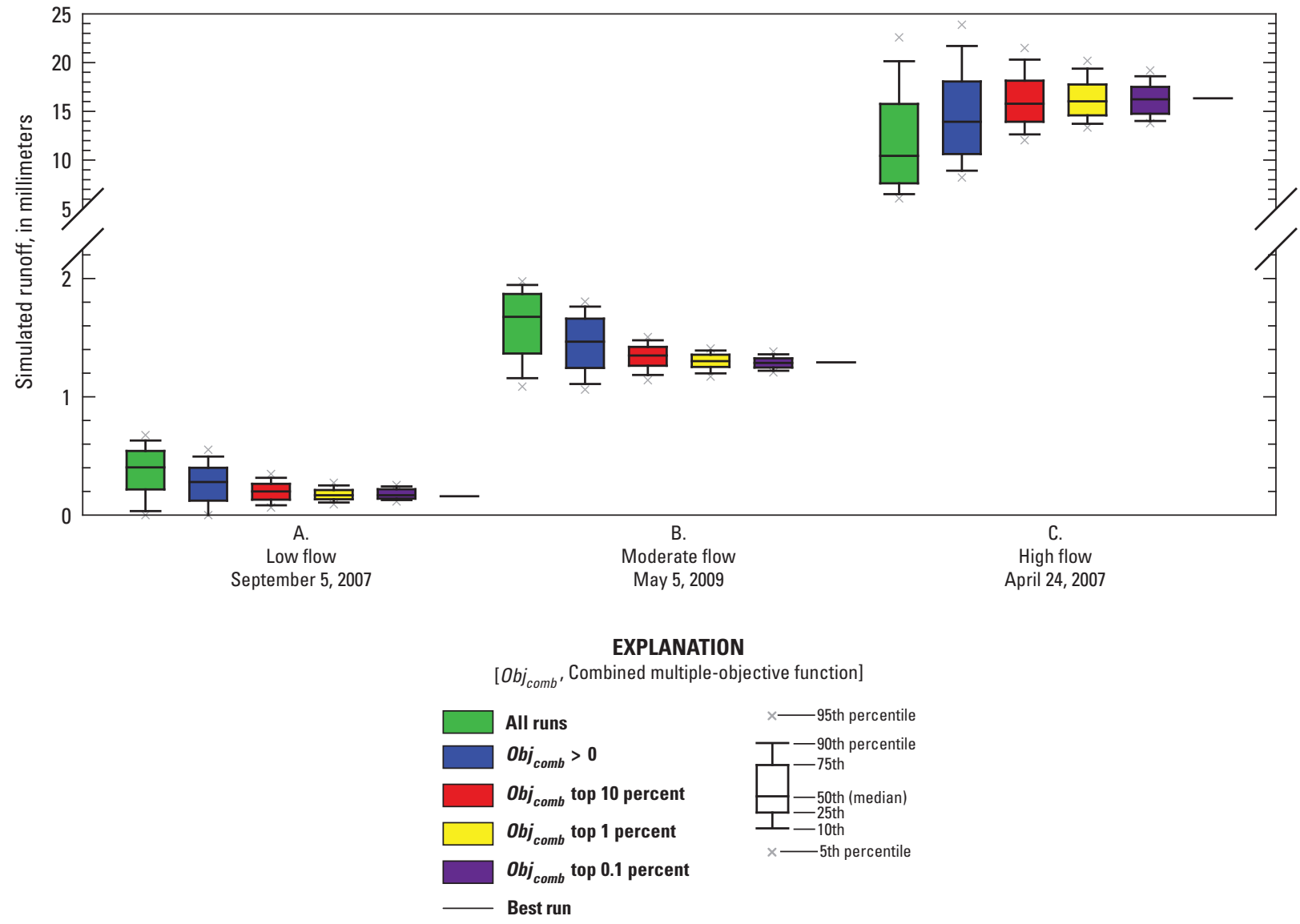

Figure 25. Boxplots of simulated runoff for $A$, low flow (September 5, 2007), $B$, moderate flow (May 5, 2009), and $C$, high flow (April 24, 2007) example days, Fishing Brook at County Line Flow near Newcomb, New York, by prediction-interval class. 


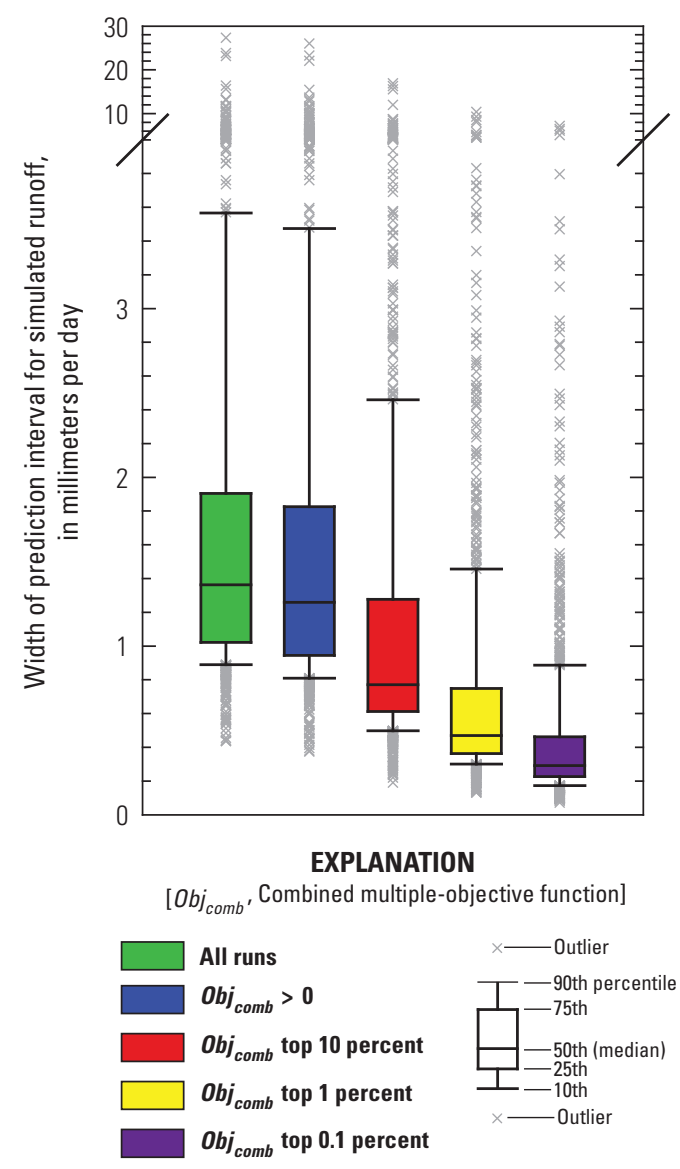

Figure 26. Width of runoff prediction intervals for the modeling period for Fishing Brook at County Line Flow near Newcomb, New York, by prediction-interval class.

Table 10. Descriptive statistics for simulated saturation deficit and depth to water table for the best run during the model period for Fishing Brook study area average, Sixmile Wetland, and example upland area.

[Study-area average topographic wetness index (TWI) is 6.86; Sixmile Wetland TWI is 11.04, and example upland area TWI is 5.00. The location of Sixmile Wetland is shown in figure 3]

\begin{tabular}{|c|c|c|c|c|c|c|}
\hline & \multicolumn{3}{|c|}{ Simulated saturation deficit, millimeters } & \multicolumn{3}{|c|}{ Simulated depth to water table, millimeters } \\
\hline & $\begin{array}{l}\text { Fishing Brook } \\
\text { study area } \\
\text { average }\end{array}$ & $\begin{array}{l}\text { Sixmile } \\
\text { wetland }\end{array}$ & $\begin{array}{c}\text { Example } \\
\text { upland area }\end{array}$ & $\begin{array}{l}\text { Fishing Brook } \\
\text { study area } \\
\text { average }\end{array}$ & $\begin{array}{l}\text { Sixmile } \\
\text { wetland }\end{array}$ & $\begin{array}{c}\text { Example } \\
\text { upland area }\end{array}$ \\
\hline Minimum, best run & 26.7 & -44.0 & 58.2 & 192 & -316 & 419 \\
\hline Median, best run & 99.3 & 28.7 & 131 & 715 & 206 & 941 \\
\hline Mean, best run & 99.0 & 28.4 & 131 & 712 & 204 & 939 \\
\hline Range, best run & 134 & 134 & 134 & 963 & 963 & 963 \\
\hline $\begin{array}{l}\text { Standard deviation, } \\
\text { best run }\end{array}$ & 26.7 & 26.7 & 26.7 & 192 & 192 & 192 \\
\hline
\end{tabular}



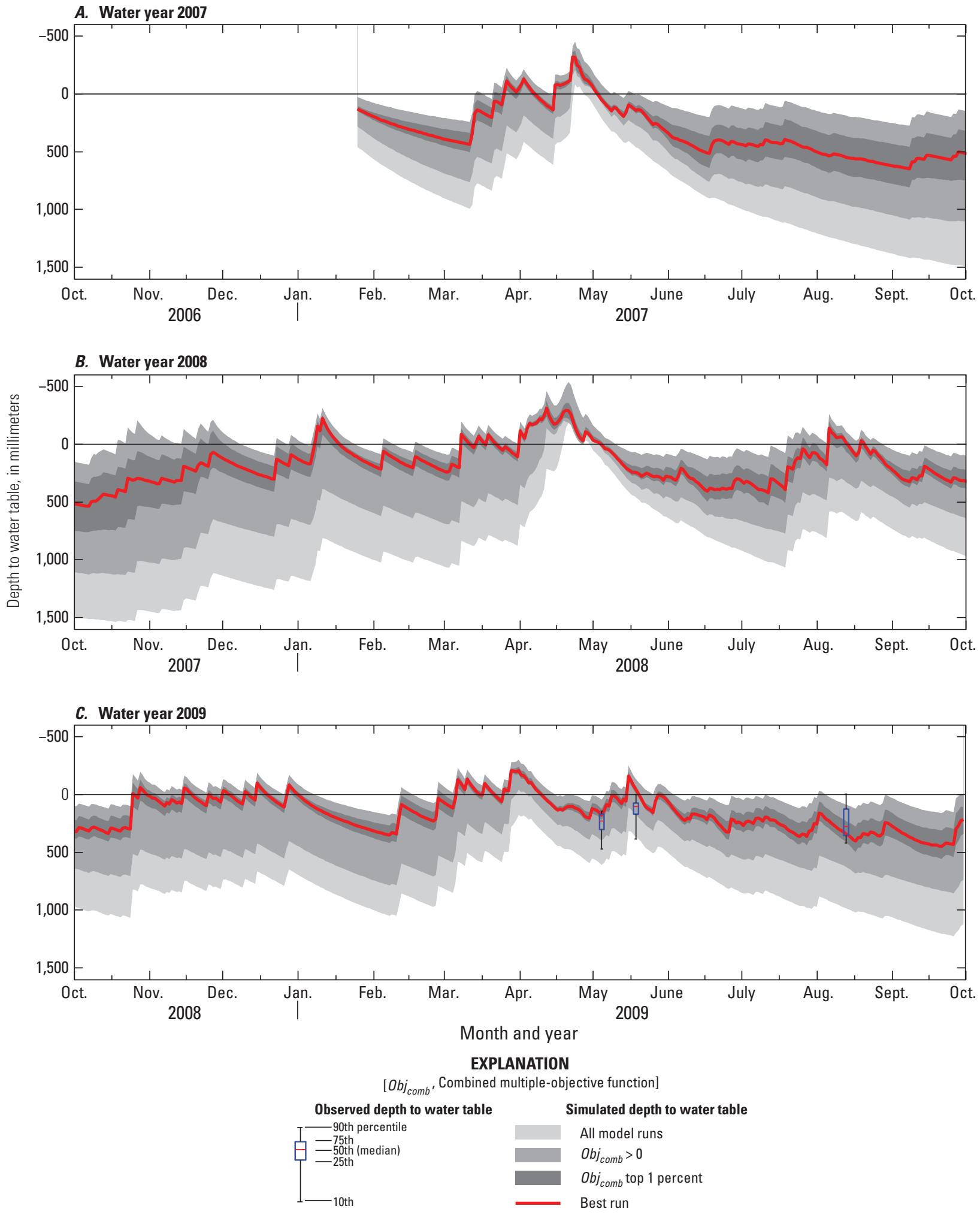

Figure 27. Simulated depth to water table at Sixmile Wetland, Fishing Brook study area, New York, best run for the modeling period and prediction intervals for $A$, water year (WY) 2007, B, WY 2008, and C, WY 2009. 


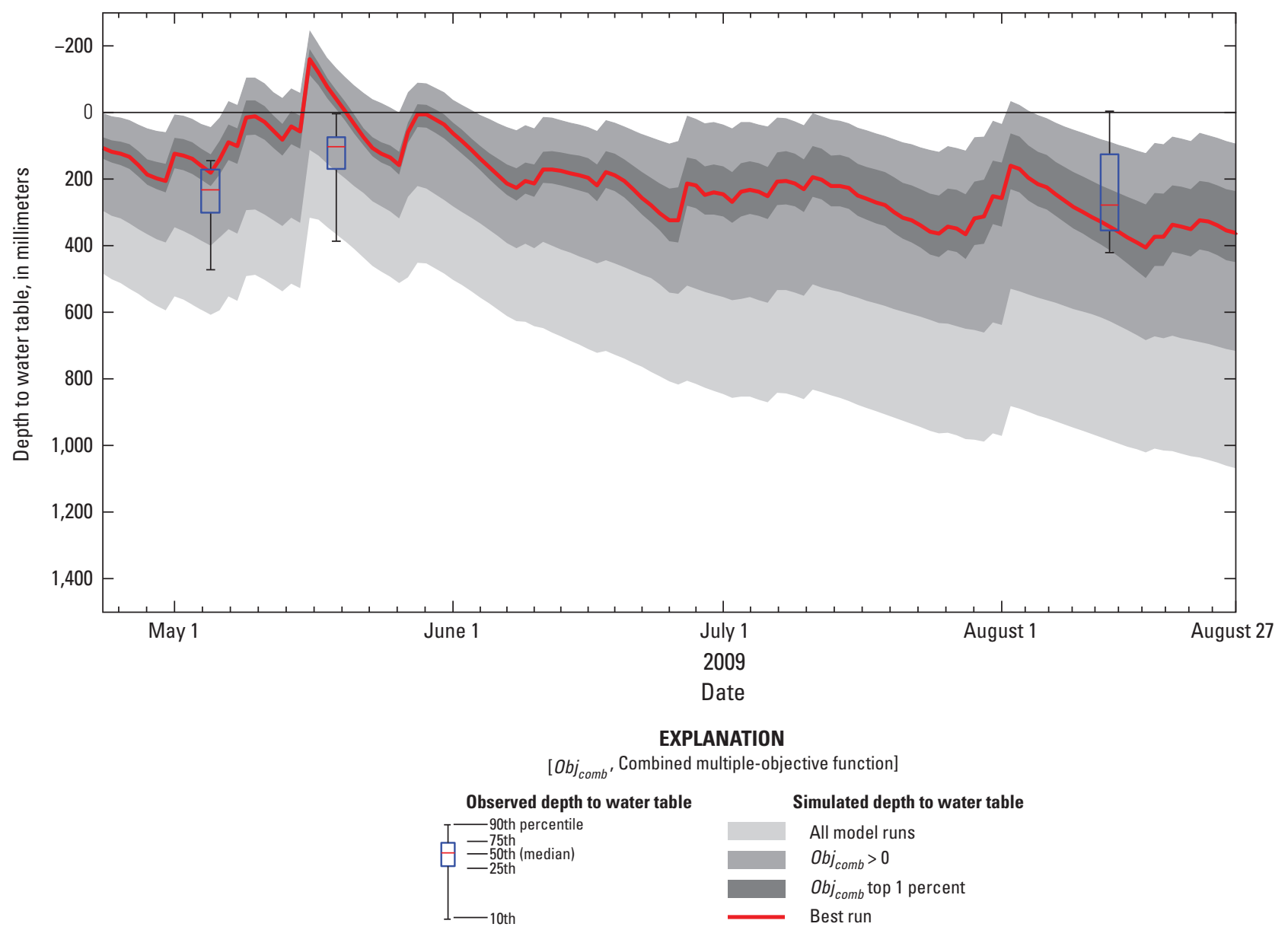

Figure 28. Simulated and observed depth to water table at Sixmile Wetland, Fishing Brook study area, New York, best run for the modeling period and prediction intervals, April-August 2009. 


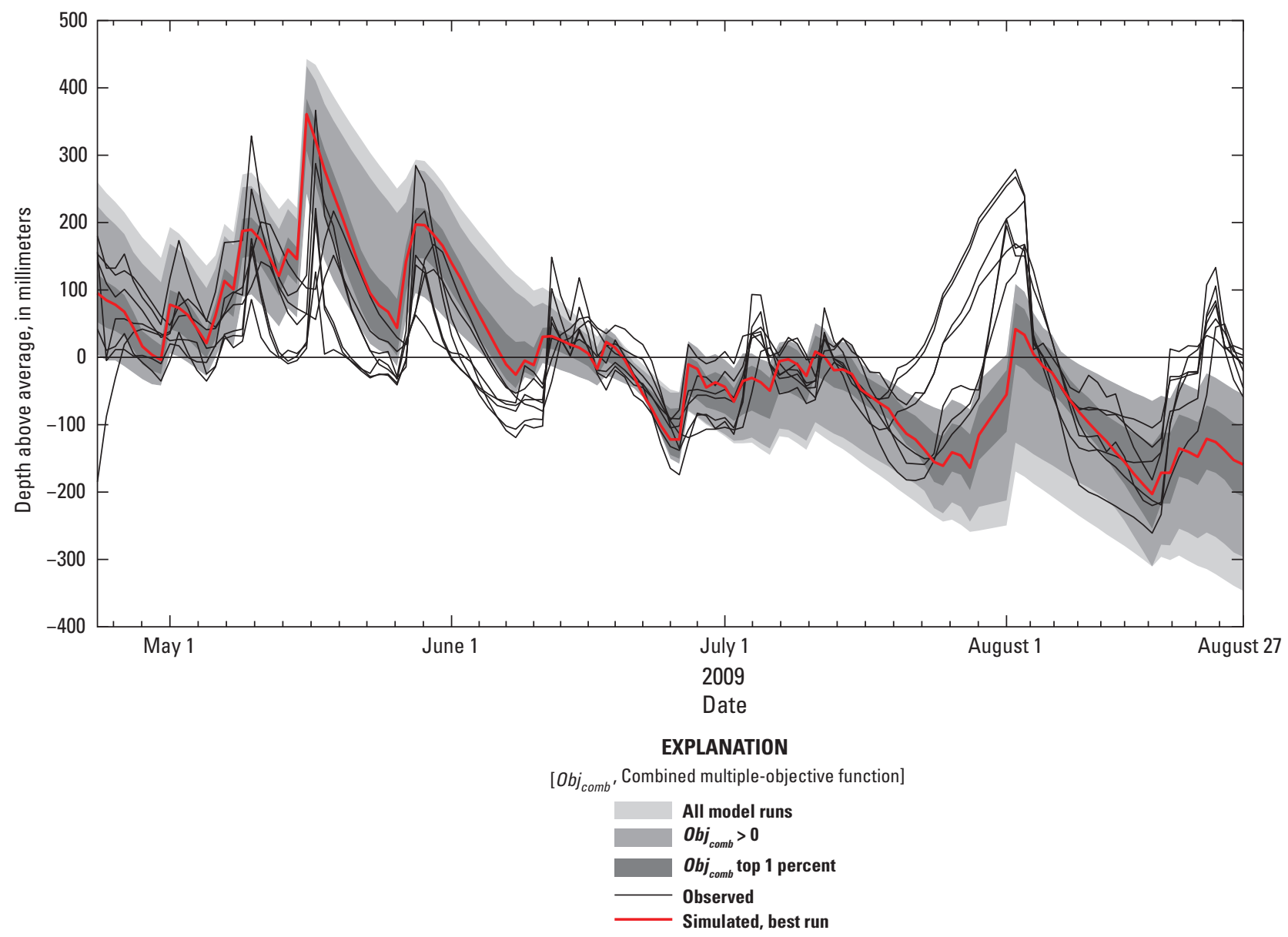

Figure 29. Simulated and observed relative depth-to-water-table fluctuations at Sixmile Wetland, Fishing Brook study area, New York, best run for the modeling period and prediction intervals, April-August 2009. 
Table 11. Simulated depth-to-water-table goodness-of-fit statistics for the best run and all model runs.

[RMSE, root mean squared error; MAE, mean absolute error; $r$, Pearson's correlation coefficient; $O b j_{D T W T S}$, relative time series depth-to-water-table objective function]

\begin{tabular}{lcccc}
\hline & \multicolumn{3}{c}{ Absolute depth to water table } & Relative fluctuations \\
\cline { 2 - 5 } & RMSE, millimeters & Bias, millimeters & MAE, millimeters & $\boldsymbol{r}^{\text {(Obj }_{\text {DTW TS }}}$ \\
\hline Best run & 91.261 & -44.422 & 86.934 & 0.624 \\
Minimum, all runs & 58.393 & -199.533 & 5.167 & .494 \\
Median, all runs & 147.615 & 63.116 & 123.177 & .540 \\
Maximum, all runs & 482.305 & 444.366 & 444.366 & .666 \\
\hline
\end{tabular}

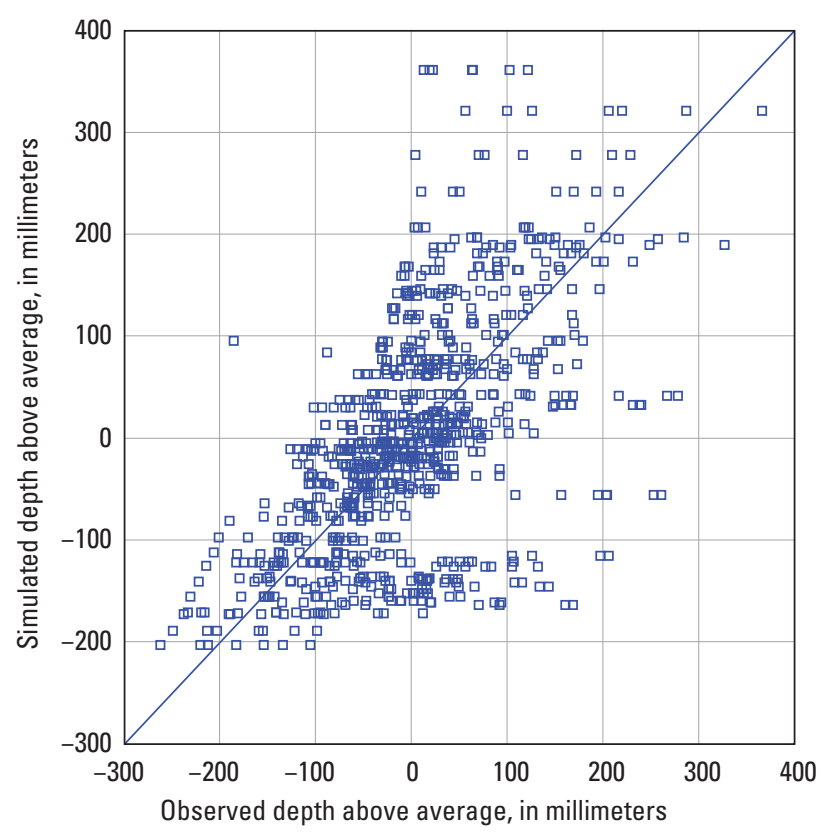

Figure 30. Scatter plot of observed and simulated depth above average at Sixmile Wetland, Fishing Brook study area, New York, April-August 2009, best run for the modeling period. The blue line represents a 1:1 correspondence of simulated and observed runoff. 


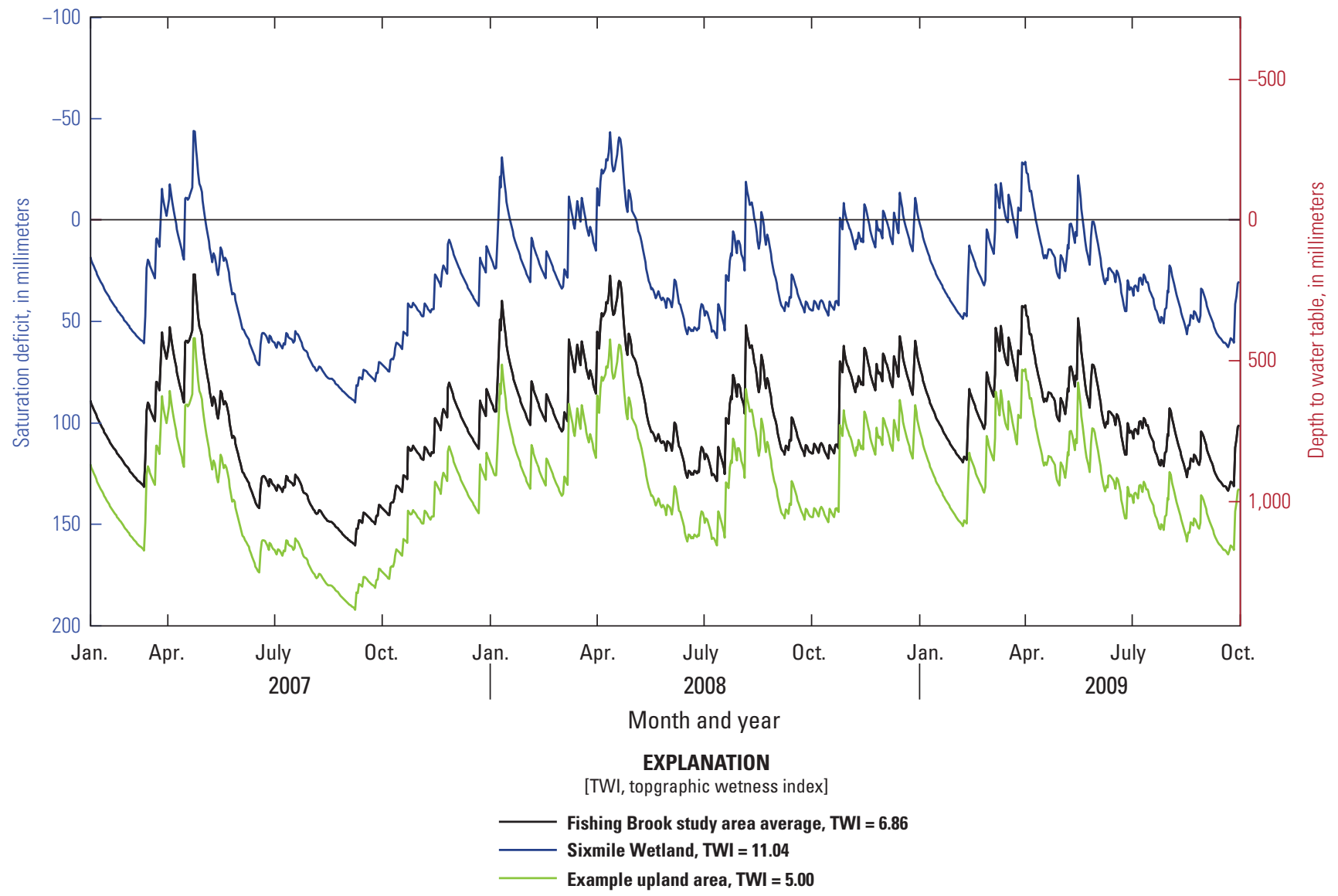

Figure 31. Simulated saturation deficit and depth to water table, Fishing Brook study area average, Sixmile Wetland, and example upland area, best run for the modeling period. 
smaller than the watershed-average saturation deficit, and the minimum simulated-saturation deficit for Sixmile Wetland is negative (table 10 and fig. 27), indicating the occurrence of surface saturation during the modeling period. Surface saturation was expected to occur at this location and was observed in the field during the modeling period (Schelker and others, 2011). Conversely, the saturation deficit predicted for an example upland area is greater than the watershed-average saturation deficit, and saturation does not occur.

TOPMODEL-simulated saturated areas in the basin ranged from 0.5 percent of basin area (not including permanently saturated areas, such as lakes and ponds) on September 5, 2007, to approximately 20 percent (inclusive of permanently saturated areas) on April 24, 2007 (fig. 32). As expected from the mathematical framework of TOPMODEL, the simulated saturated-area time series follows a similar form to that of the simulated basin-average saturation deficit. A map of the range of predicted saturated areas (fig. 33), generated using the TWI distribution for the study area, shows that during low-flow conditions (high saturation deficit), mainly riparian areas and stream cells are predicted to be saturated. During high-flow (low saturation deficit) conditions, the mapped saturated areas extend throughout wetlands and farther upstream in the watershed, likely along ephemeral-stream channels. Schelker and others (2011) predicted a range of 6 to 12 percent saturation for the period January 2007-June 2008, including 5 percent of the basin considered permanently saturated, consisting mainly of open water and adjacent areas. The minimum saturated areas reported in this report agree well with those reported by Schelker and others (2011) when permanently saturated areas are taken into account. The maximum saturated areas reported in this report are greater than those reported by Schelker and others (2011); this may reflect differences in computed watershed characteristics or calibrated parameter values.

\section{Prediction-Interval Uncertainty Analysis}

The prediction intervals for simulated-saturation deficit (figs. 15-17) and depth to water table (fig. 27), like those for runoff, generally follow the form of the model run with the highest combined-objective function. The range of predicted saturation-deficit values is directly related to the magnitude of the deficit (fig. 34), but is more consistent among flow and saturation conditions than runoff. The prediction intervals (table 12 and fig. 35) are more distinct between classes, with less overlap than those for runoff and less skewness in their variation over time. The ratio of the median prediction interval to the median saturation deficit is similar for most classes, but the ratio of the median prediction interval to the range of saturation deficit values is much larger than for runoff (table 12). As one moves from all model runs to ranges of model runs with progressively better fits to the combined-objective function (fig. 34), the median and range of saturation-deficit values moves towards lower-saturation deficits (wetter conditions).

The variability of simulated depth to water table for a single time step (fig. 36) and the prediction intervals for depth to water table (fig. 37) are similar to those for the saturation deficit. The median prediction-interval width for the top 0.1 percent of model runs was approximately $80 \mathrm{~mm}$ (table 13); this is equal to about 10 percent of the median prediction-interval width for all model runs. An interesting artifact of the relative-depth-to-water-table computations is that the variability of simulated depth above average (fig. 29) is much less than that for absolute depth to water table (fig. 28). The process of removing the average from the fluctuations removed much of the spread seen in the absolute depth-to-water simulations, indicating that most simulations follow a similar form with a simple offset in the mean value.

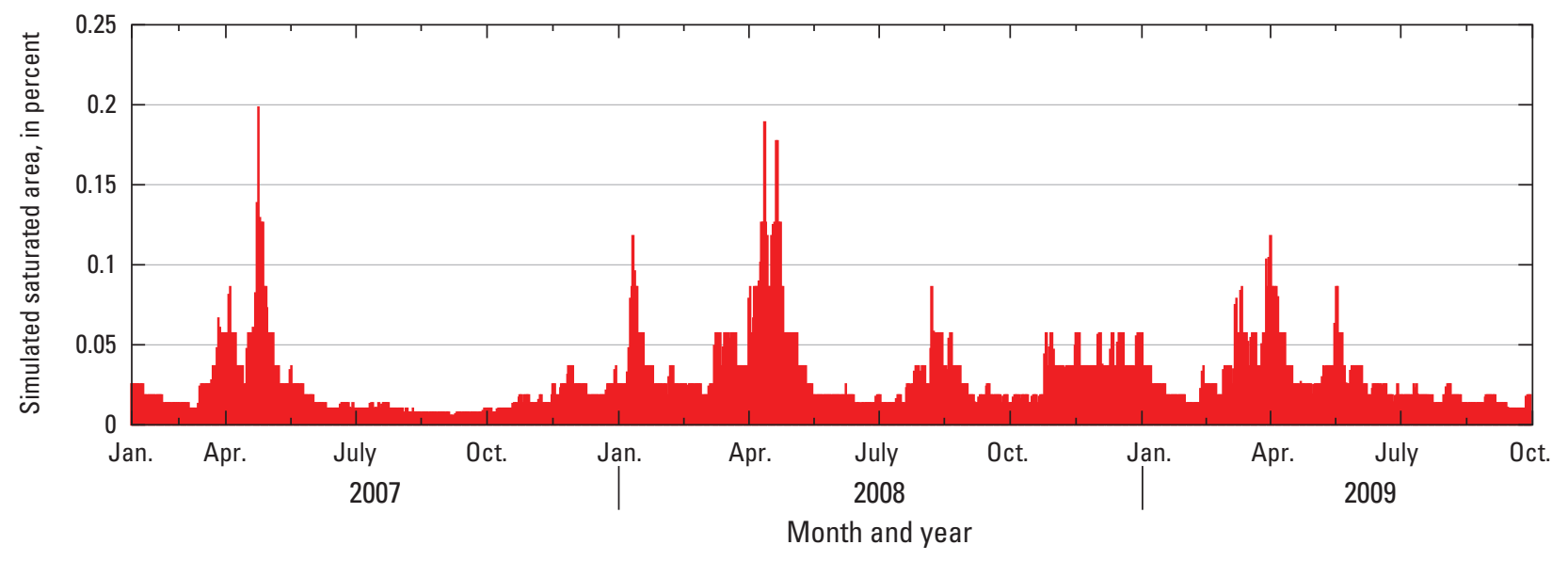

Figure 32. Simulated saturated area, as percent of Fishing Brook study area, New York, best run for the modeling period. 


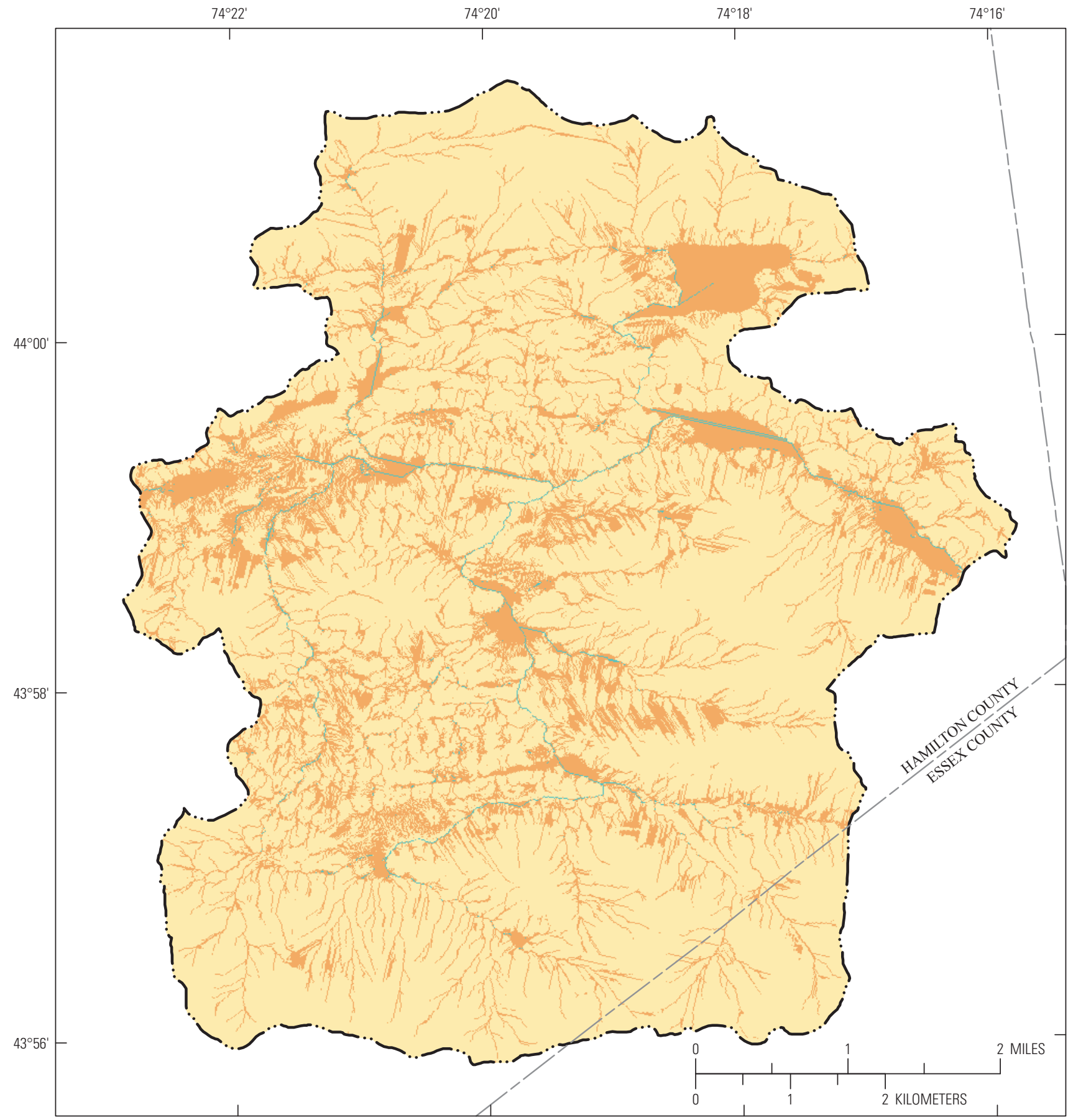

Base from National Elevation Dataset, 2009, 1/3 arc-second Universal Transverse Mercator projection Zone 18

EXPLANATION

Simulated saturated areas

Minimum -0.5 percent of watershed, 9/5/2007

Maximum-19.8 percent of watershed, 4/24/2007

- Watershed boundary

Figure 33. Simulated saturated areas, showing minimum and maximum saturation of Fishing Brook study area, New York, best run for the modeling period. 


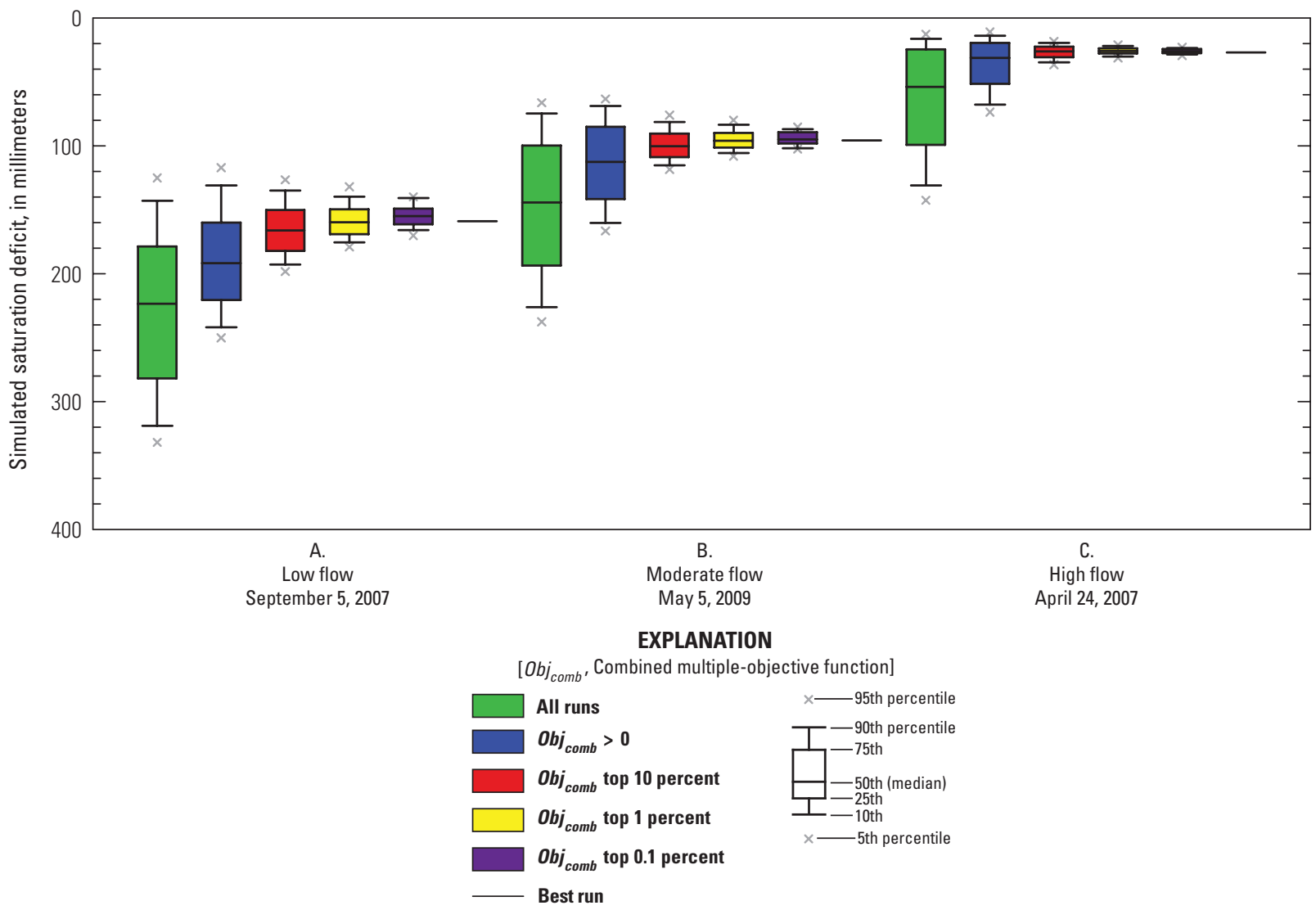

Figure 34. Boxplots of simulated watershed-average saturation deficit for $A$, low flow (September 5,2007 ), $B$, moderate flow (May 5, 2009), and $C$, high flow (April 24, 2007) example days, Fishing Brook study area, New York, by prediction-interval class.

Table 12. Saturation-deficit prediction-interval widths, by prediction-interval class.

[mm, millimeter; $\boldsymbol{S}$, saturation deficit; $O b_{c o m b}$, weighted combined multiple-objective function; \%, percent, >, greater than]

\begin{tabular}{|c|c|c|c|c|c|}
\hline & $\begin{array}{l}\text { Minimum width of } \\
\text { prediction interval, } \\
\text { mm }\end{array}$ & $\begin{array}{c}\text { Median width of } \\
\text { prediction interval, } \\
\text { mm }\end{array}$ & $\begin{array}{l}\text { Maximum width of } \\
\text { prediction interval, } \\
\text { mm }\end{array}$ & $\begin{array}{c}\text { Ratio, median width } \\
\text { to best run median } S \\
(99.3 \mathrm{~mm})\end{array}$ & $\begin{array}{c}\text { Ratio, median width } \\
\text { to best run } S \text { range } \\
\text { (134 } \mathrm{mm})\end{array}$ \\
\hline $\mathrm{O} b j_{\text {comb }}$ top $0.1 \%$ & 8.50 & 28.6 & 49.9 & 0.288 & 0.214 \\
\hline$O b j_{\text {comb }}$ top $1 \%$ & 15.9 & 5.80 & 95.3 & .511 & .379 \\
\hline$O b j_{\text {comb }}$ top $10 \%$ & 26.0 & 78.0 & 142 & .785 & .582 \\
\hline$O b j_{c o m b}>0$ & 69.5 & 162 & 253 & 1.63 & 1.21 \\
\hline
\end{tabular}




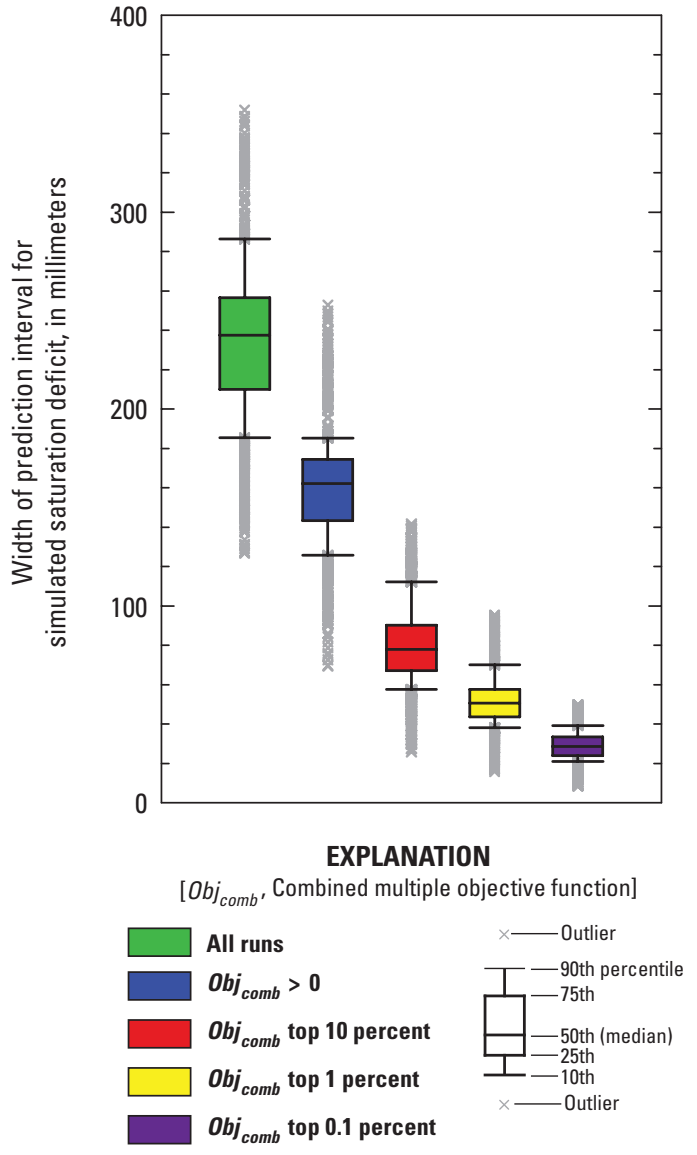

Figure 35. Width of simulated watershed-average saturation deficit prediction intervals for the modeling period, Fishing Brook study area, New York, by prediction-interval class. 


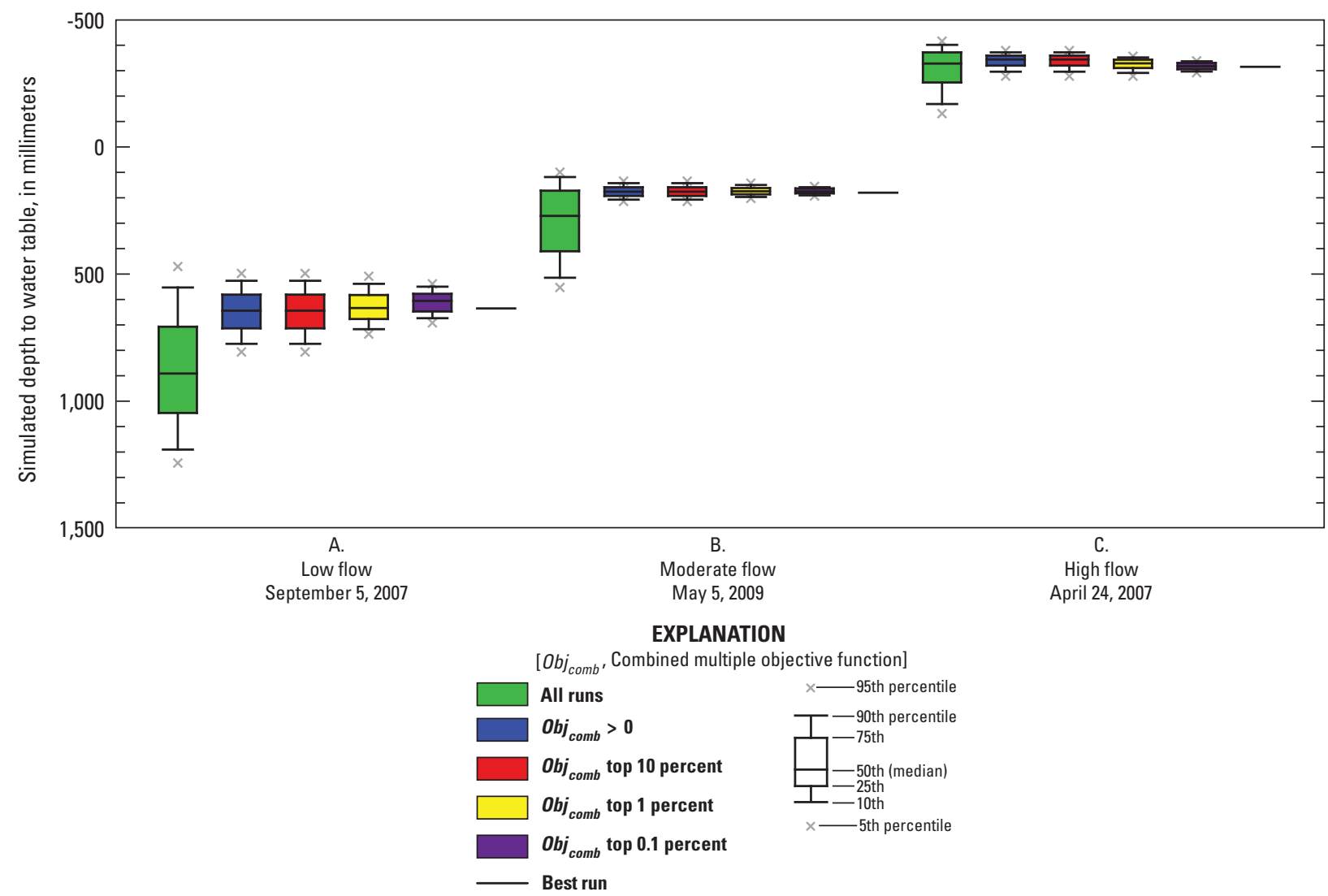

Figure 36. Boxplots of simulated depth to water table at Sixmile Wetland, Fishing Brook study area, New York, for $A$, low flow (September 5, 2007), $B$, moderate flow (May 5, 2009), and $C$, high flow (April 24, 2007) example days, by prediction-interval class. 

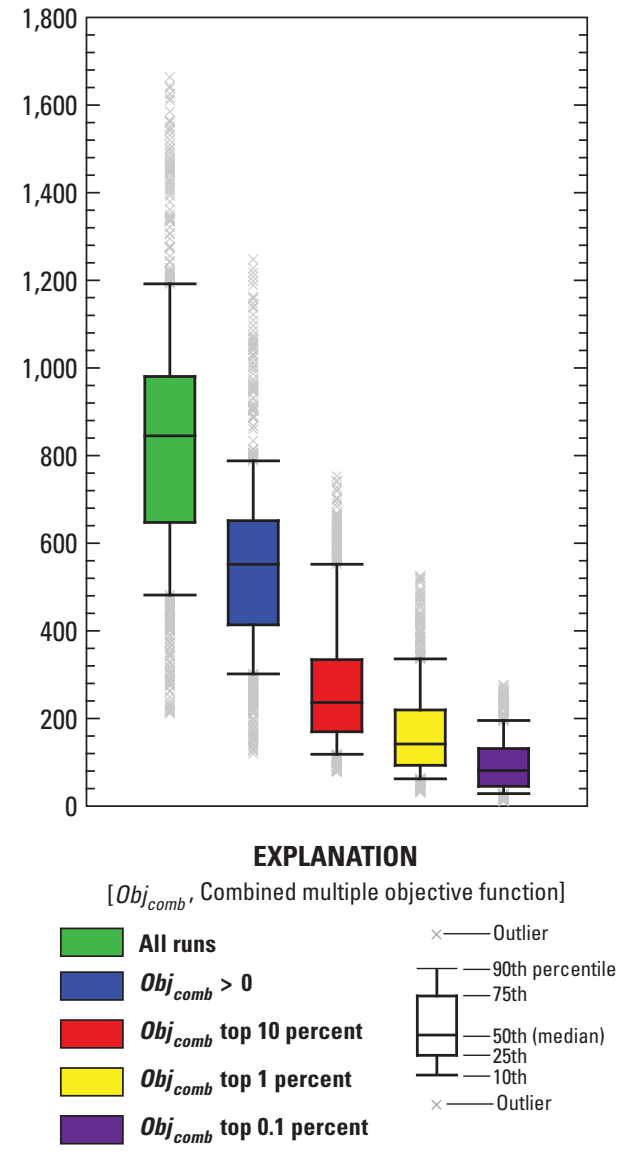

Figure 37. Width of simulated depth-to-water-table prediction intervals for the modeling period, Fishing Brook study area, New York, by prediction-interval class.

Table 13. Depth to water table in Sixmile Wetland prediction-interval widths, by prediction-interval class.

[mm, millimeter; DTW, depth to water; SMW, Sixmile Wetland; $O b j_{c o m b}$, weighted combined multiple-objective function; \%, percent; >, greater than]

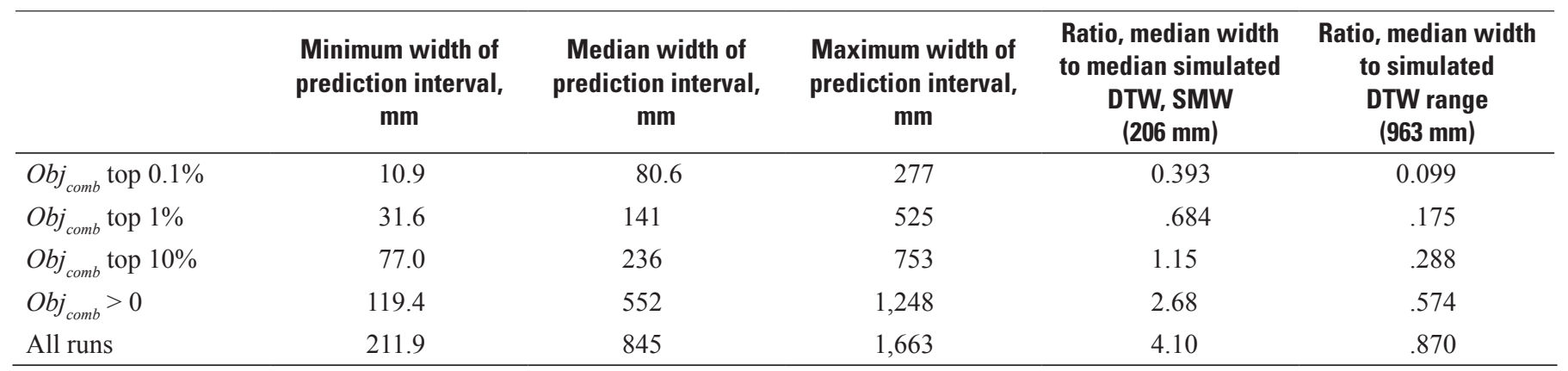




\section{Application of Calibration to Subwatersheds}

For use of the TOPMODEL simulations in other modeling and water-quality applications, the results of the calibration were applied to several subwatersheds within the study area (fig. 2). Subwatersheds were defined for modelassessment points (MAxx) for input into $\mathrm{Hg}$ models, and at additional synoptic sites ( $\mathrm{SS} x x$ ) where samples for $\mathrm{Hg}$ analysis were collected; the entire study area is designated MA06. To produce a simulated time series of runoff and saturation deficit for each subwatershed, watershed characteristics (table 14) and the TWI distribution were calculated for each subwatershed; model parameter values from the overall study area model run with the highest combined-objective value (table 5) then were applied to TOPMODEL for each subwatershed.

Subwatersheds ranged in area from $0.96 \mathrm{~km}^{2}$ (MA13) to $60.60 \mathrm{~km}^{2}$ (MA05). Many of the subwatersheds were nested; for example, subwatershed MA03 contained subwatersheds
MA01 and MA02 (fig. 2). The watershed-average TWI varied from $5.95 \ln (\mathrm{m})$ for MA13 (table 14), a small, steep watershed with almost no wetlands (figs. 2 and 3); to $7.37 \ln (\mathrm{m})$ for MA09, a watershed that contains large portions of the Sixmile Wetland (figs. 2 and 3). TOPMODEL results for the subwatersheds are illustrated by these two basins to show the range in simulated values among the subwatersheds.

Simulated runoff for the subwatersheds is similar to that for the whole study area (fig. 38); responses to rainfall events are initially higher in subwatershed MA13 (the smaller, steeper basin), whereas the recession curve typically is more sustained in subwatershed MA09 (the larger, flatter basin with more wetlands). The simulated-saturation deficits for the two subwatersheds also are similar to those for the whole study area (fig. 39); although, surprisingly, the watershed-average saturation deficit for subwatershed MA13 is slightly less than that of subwatershed MA09. The computed watershed-average depth to water table shows the same patterns as the simulatedsaturation deficits.

Table 14. Subwatershed characteristics for the Fishing Brook study area.

[TWI, topographic wetness index; ln m, natural logarithm (meters); model-assessment points are shown in figure 2; MA06 is the main study area]

\begin{tabular}{|c|c|c|c|c|c|}
\hline Watershed & $\begin{array}{c}\text { Total area } \\
\text { (square kilometers) }\end{array}$ & $\begin{array}{c}\text { Lake area } \\
\text { (square kilometers) }\end{array}$ & $\begin{array}{c}\text { Stream area } \\
\text { (square kilometers) }\end{array}$ & $\begin{array}{c}\text { Uplake area } \\
\text { (decimal percent) }\end{array}$ & $\begin{array}{c}\text { Watershed average } \\
\text { TWI } \\
\text { (In } \mathrm{m})\end{array}$ \\
\hline MA01 & 20.69 & 0.11 & 0.12 & 0.00 & 6.54 \\
\hline MA02 & 27.06 & .31 & .15 & .99 & 6.63 \\
\hline MA03 & 3.04 & .32 & .16 & .89 & 6.67 \\
\hline MA04 & 49.98 & .46 & .29 & .54 & 6.84 \\
\hline MA06 & 65.64 & 1.75 & .34 & 1.00 & 6.86 \\
\hline MA07 & 4.73 & .07 & .03 & .00 & 6.37 \\
\hline MA08 & 7.33 & .08 & .05 & .00 & 6.63 \\
\hline MA09 & 9.68 & .02 & .07 & .00 & 7.37 \\
\hline MA13 & .96 & .00 & .01 & .00 & 5.95 \\
\hline SS01 & 15.85 & .08 & .08 & .00 & 6.45 \\
\hline $\mathrm{SS} 02$ & 4.57 & .02 & .04 & .00 & 6.94 \\
\hline $\mathrm{SS} 03$ & 24.99 & .11 & .14 & .00 & 6.57 \\
\hline SS04 & 17.74 & .11 & .12 & .00 & 7.07 \\
\hline SS05 & 17.04 & .10 & .11 & .00 & 7.05 \\
\hline SS06 & 6.88 & .08 & .04 & .00 & 6.58 \\
\hline SS07 & 1.31 & .00 & .01 & .00 & 5.99 \\
\hline
\end{tabular}



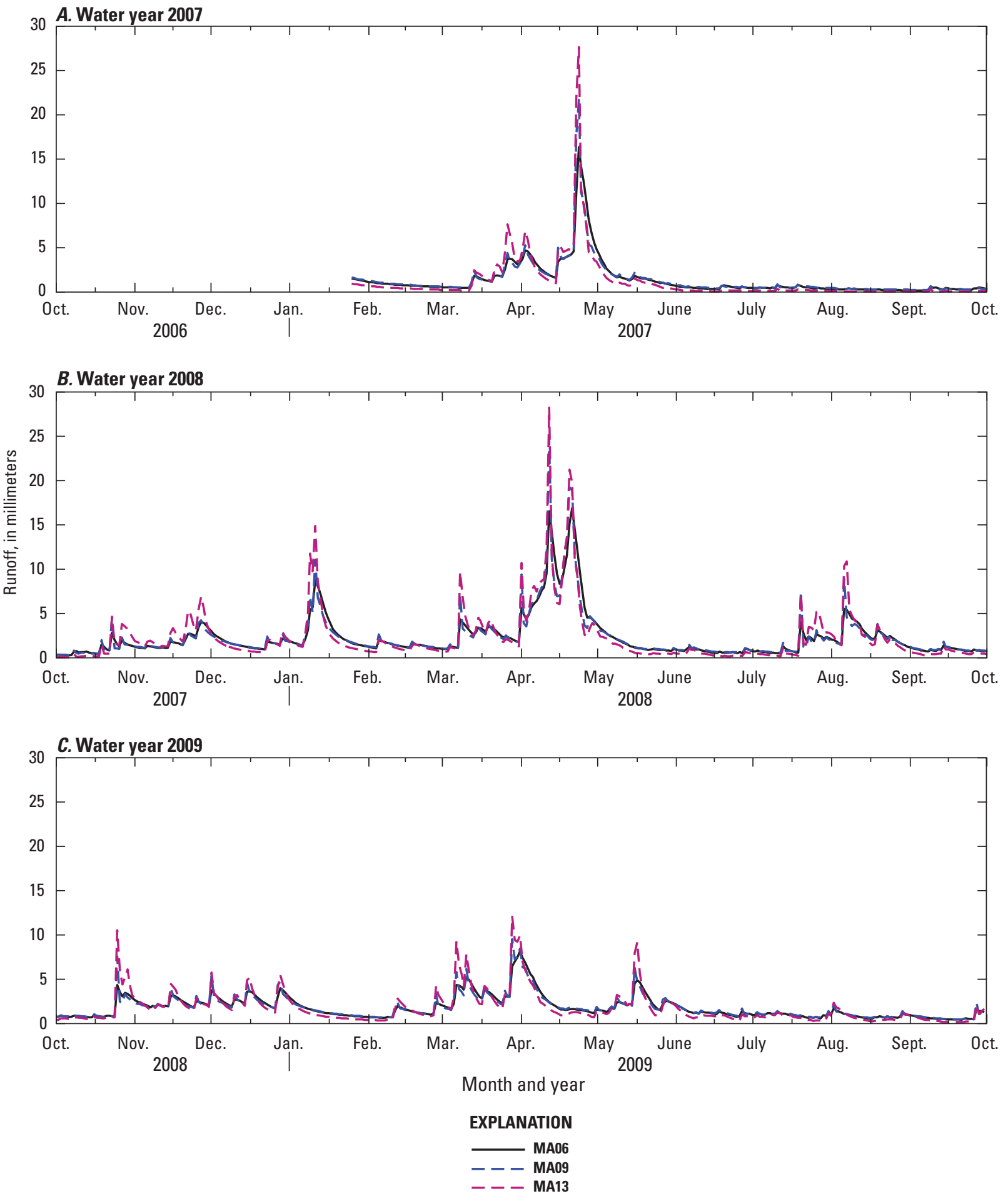

Figure 38. Simulated runoff for selected subwatersheds, Fishing Brook study area, New York, for $A$, water year (WY) 2007, B, WY 2008, and C, WY 2009. 
A. Water year 2007

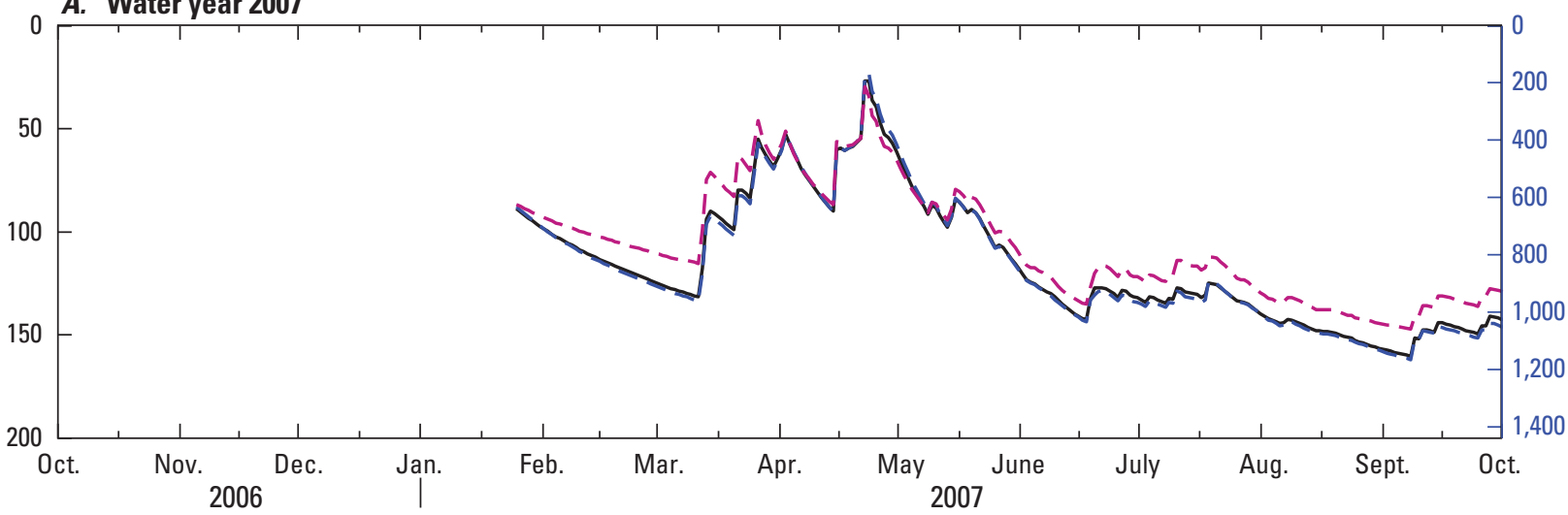

B. Water year 2008
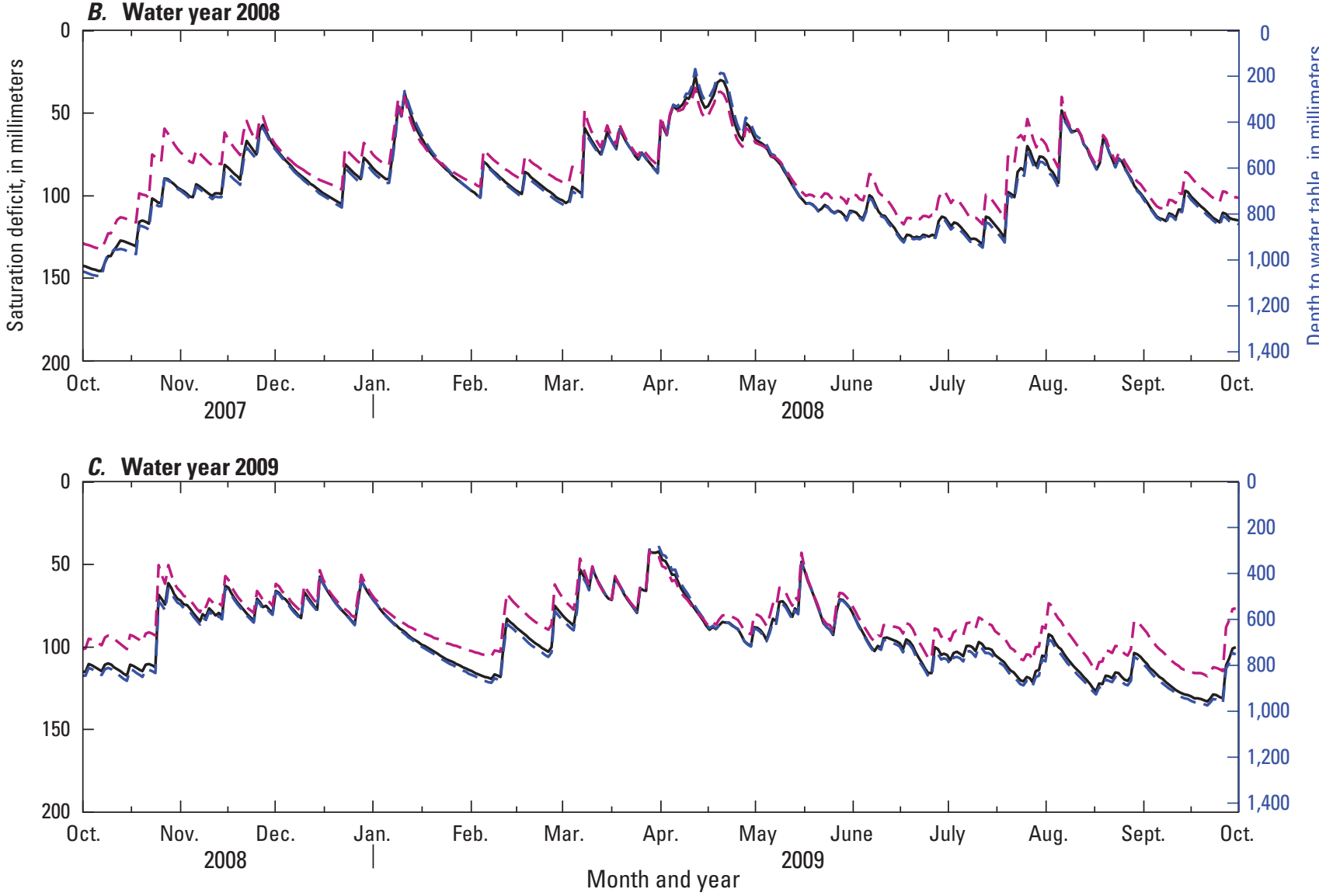

EXPLANATION

- MA06

--- MA13

Figure 39. Simulated saturation deficit and watershed-average depth to water table for selected subwatersheds for $A$, water year (WY) 2007, B, WY 2008, and C, WY 2009. 
In addition to the continuous record of streamflow available at the outlet of the study area, streamflow measurements were made at selected sites throughout the basin (table 15 and fig. 2) several times during the modeling period as part of synoptic surveys of the concentrations of $\mathrm{Hg}$ species. For some sites, on some occasions more than one measurement was made during a day; these measurements were averaged for analysis. After screening for multiple measurements, there were 66 measurements made at 11 sites (table 15); runoff measured at these sites ranged from 0.02 to $21 \mathrm{~mm} / \mathrm{d}$. A scatter plot shows some correlation of observed runoff and simulated runoff (fig. 40). Some individual measurements show better agreement with the subwatershed simulated runoff (overall Pearson correlation coefficient 0.654 ) than with the simulated runoff for the entire study area (correlation coefficient 0.653 ), but comparison to gaged runoff at the study-area outlet yields the best correlation coefficient (0.708).

Table 15. Streamflow measurements at synoptic survey sites for the Fishing Brook study area, New York, $2007-09$.

[Model-assessment points are shown in figure 2]

\begin{tabular}{|c|c|c|c|}
\hline $\begin{array}{c}\text { Station } \\
\text { identification } \\
\text { number }\end{array}$ & $\begin{array}{c}\text { Model- } \\
\text { assessment } \\
\text { point }\end{array}$ & Station name & $\begin{array}{c}\text { Number of } \\
\text { measurements } \\
\text { available }\end{array}$ \\
\hline 01311990 & MA02 & Fishing Brook at $28 \mathrm{~N}$ near Long Lake NY & 7 \\
\hline 0131199040 & MA05 & Fishing Brook Above County Line Flow near Long Lake NY & 6 \\
\hline 0131199035 & MA12 & Pickwacket Pond Outlet at mouth near Long Lake NY & 6 \\
\hline 0131199045 & MA13 & Unnamed Tributary to County Line Flow near Long Lake NY & 7 \\
\hline 01311985 & $\mathrm{SS} 01$ & Fishing Brook near Windfall Mountain near Long Lake NY & 3 \\
\hline 0131199010 & $\mathrm{SS} 02$ & Sixmile Brook at 28N near Long Lake NY & 7 \\
\hline 01311989 & $\mathrm{SS} 03$ & Fishing Brook near Long Lake NY & 3 \\
\hline 0131199022 & $\mathrm{SS} 04$ & Sixmile Brook near Long Lake NY & 12 \\
\hline 0131199021 & SS05 & Sixmile Brook below Sixmile Brook Tributary near Long Lake NY & 6 \\
\hline 0131199020 & SS06 & Sixmile Brook Tributary near Long Lake NY & 5 \\
\hline 0131199029 & SS07 & Pickwacket Pond Inlet near Long Lake NY & 4 \\
\hline
\end{tabular}

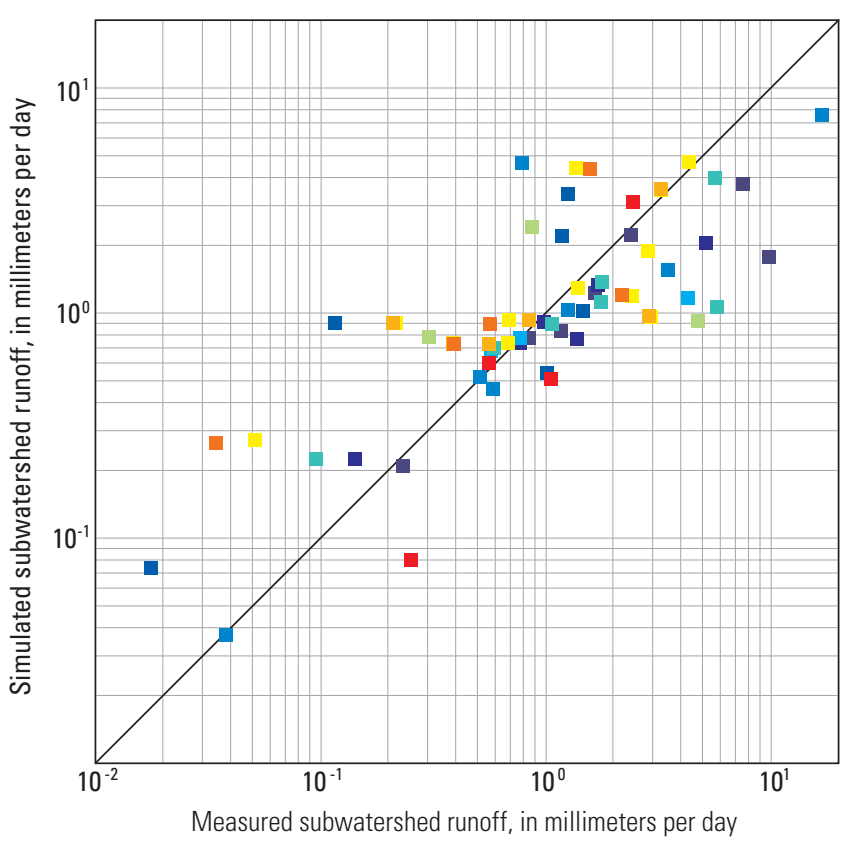

EXPLANATION

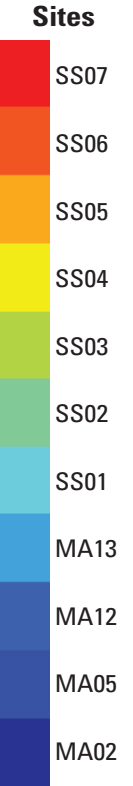

Figure 40. Scatter plot of simulated runoff and observed runoff for selected subwatersheds, Fishing Brook study area, New York. 


\section{Summary}

TOPMODEL, a physically based, variable-source area rainfall-runoff model, was applied for the period January 2007-September 2009 to model streamflow and depth to water table in the medium-sized (65.6 square kilometers) Fishing Brook Watershed, which is located in northern New York. The study area is mainly forested, with substantial wetland area and little impervious surface. This application of TOPMODEL is part of a larger U.S. Geological Survey National WaterQuality Assessment Program study of mercury $(\mathrm{Hg})$ cycling; model-hydrology results will be linked (in the future) with models to simulate $\mathrm{Hg}$ in the study watershed.

A Monte-Carlo calibration with a combined multipleobjective function was applied to calibrate runoff at the study area outlet and depth to water table at Sixmile Wetland. The combined multiple-objective function included terms representing the Nash-Sutcliffe efficiency of the natural log of runoff at the study area outlet, the root mean squared error of the absolute depth to water table in Sixmile Wetland, and the Pearson correlation coefficient $(r)$ of the relative fluctuations of depth to water table in Sixmile Wetland. Runoff was weighted equally with depth to water table in the combined multiple-objective function. Snowmelt parameters were calibrated separately from main model parameters to allow for variability in snowmelt-parameter values on a yearly basis; snowmelt calibration was evaluated using the Nash-Sutcliffe efficiency of the runoff at the study area outlet.

The single "best" run as selected from 100,000 TOPMODEL runs by the combined multiple-objective function was compared to observed runoff and depth to water table. The simulated runoff generally matched observed runoff well, with an overall Nash-Sutcliffe efficiency of 0.738 , but the model underpredicted total runoff by 14 percent. Depth to water table computed from simulated saturation-deficit values matched observed water table depth moderately well. The root mean squared error of absolute depth to water table was 91 millimeters $(\mathrm{mm})$; comparatively, the mean depth to water table on three observation dates was $205 \mathrm{~mm}$. The Pearson correlation coefficient (r) for the depth-to-water-table fluctuations was 0.624 .

The variability of the TOPMODEL predictions as a function of model parameters was assessed using a simplified prediction-interval uncertainty assessment. Prediction intervals for runoff and saturation deficit generally followed the form of the model run with the highest combined objective value, but some deviation from this form was observed, especially in the time series of runoff. The width of prediction intervals compared to range over time was greater for the simulated saturation deficit than for runoff; the variability of predictioninterval widths over time (and with basin-average saturation condition) was greater for runoff than for saturation deficit.

The calibrated TOPMODEL results for the entire study area were applied to several subwatersheds within the study area using computed properties of the subwatersheds. Simulated runoff in subwatersheds varies as would be expected based on subwatershed characteristics, but a comparison of observed instantaneous runoff at subwatersheds shows better agreement with observed runoff for the overall study area than with simulated runoff.

\section{References Cited}

Band, L.E., Patterson, Pitman, Nemani, Ramakrishna, and Running, S.W., 1993, Forest ecosystem processes at the watershed scale-Incorporating hillslope hydrology: Agricultural and Forest Meteorology, v. 63, p. 93-126.

Beven, K.J., ed., 1997, Distributed hydrological modellingApplications of the TOPMODEL concept: Chichester, Wiley, $348 \mathrm{p}$.

Beven, K.J., 2001, Rainfall-runoff modelling-The primer: Chichester, Wiley, $360 \mathrm{p}$.

Beven, K.J., and Binley, A.M., 1992, The future of distributed models-Model calibration and uncertainty prediction: Hydrological Processes, v. 6 no. 3, p. 279-298.

Beven, K.J., and Kirkby, M.J., 1979, A physically based, variable contributing area model of basin hydrology: Hydrological Sciences Bulletin, v. 24, p. 43-69.

Beven, K.J., Lamb, R., Quinn, P.F., Romanowicz, R., Freer, J., 1995, TOPMODEL, in Singh, V.P., ed., Computer models of watershed hydrology: Highlands Ranch, Colo., Water Resources Publications, p. 627-668.

Blazkova, S., Beven, K., Tacheci, P., and Kulasova, A., 2002, Testing the distributed water table predictions of TOPMODEL (allowing for uncertainty calibration) - The death of TOPMODEL?: Water Resources Research, v. 38, no. 11, p. $1257-1268$.

Boyer, E.W., Hornberger, G.M., Bencala, K.E., and McKnight, D.M., 1996, Overview of a simple model describing variation of dissolved organic carbon in an upland catchment: Ecological Modeling, v. 85, p. 183-188.

Cadwell, D.H., 1991, Surficial geologic map of New York: New York State Museum Map and Chart Series No. 40, Adirondack sheet scale 1:250,000.

Chen, C.W., and Herr, J.W., 2010, Simulating the effect of sulfate addition on methylmercury output from a wetland: Journal of Environmental Engineering, v. 136, p. 354-362.

Chen, C.W., Herr, J.W., and Goldstein, R.A., 2008, Model calculations of total maximum daily loads of mercury for drainage lakes: Journal of the American Water Resources Association, v. 44, p. 1295-1307. 
Clean Air Status and Trends Network, 2010, Huntington Wildlife Forest (site HWF187) hourly meteorological data, accessed January 29, 2010, at http://java.epa.gov/castnet/ epa_jsp/prepackageddata.jsp.

Driscoll, C.T., Blette, V., Yan, C., Schofield, C.L., Munson, R., and Holsapple, J., 1995, The role of dissolved organic carbon in the chemistry and bioavailability of mercury in remote Adirondack lakes: Water, Air, and Soil Pollution, v. 80, p. $499-508$.

Feaster, T.D., Golden, H.E., Odom, K.R., Lowery, M.A., Conrads, P.A., and Bradley, P.M., 2010, Simulation of streamflow in the McTier Creek watershed, South Carolina: U.S. Geological Survey Scientific Investigations Report 2010-5202, $61 \mathrm{p}$.

Fisher, D.W., Isachsen, Y.W., and Rickard, L.V., 1970, Geologic map of New York State: New York State Museum Map and Chart Series No. 15, Adirondack sheet, scale 1:250,000.

Gesch, D., Oimoen, M., Greenlee, S., Nelson, C., Steuck, M., and Tyler, D., 2002, The National Elevation Dataset: Photogrammetric Engineering and Remote Sensing, v. 68, no. 1 , p. 5-11.

Gray, D.M., and Prowse, T.D., 1992, Snow and floating ice, chapter 7, in Maidment, D.R., ed., Handbook of hydrology: New York, McGraw-Hill, p. 7.1-7.58.

Hamon, W.R., 1961, Estimating potential evapotranspiration: Journal of the Hydraulic Division, Proceedings of the American Society of Civil Engineers, v. 87, p. 107-120.

Homer, C., Huang, C., Yang, L., Wylie, B., and Coan, M., 2004, Development of a 2001 National Landcover Database for the United States: Photogrammetric Engineering and Remote Sensing, v. 70, no. 7, p. 829-840.

Hornberger, G.M., Bencala, K.E., and McKnight, D.M., 1994, Hydrological controls on dissolved organic carbon during snowmelt in the Snake River near Montezuma, Colorado: Biogeochemistry, v. 25, p. 147-165.

Hornberger, G.M., Beven, K.J., Cosby, B.J., and Sappington, D.E., 1985, Shenandoah watershed study - Calibration of a topography-based, variable contributing area hydrological model to a small forested catchment: Water Resources Research, v. 21, no. 12, p. 1841-1850.

Hornberger, G.M., and Spear, R.C., 1981, An approach to the preliminary analysis of environmental systems: Journal of Environmental Management, v. 12, p. 7-18.

Kennen, J.G., Kauffman, L.J., Ayers, M.A., Wolock, D.M., and Colarullo, S.J., 2008, Use of an integrated flow model to estimate ecologically relevant hydrologic characteristics at stream biomonitoring sites: Ecological Modelling, v. 211, p. 57-76.
Kirkby, M.J., 1975, Hydrograph modelling strategies, in Peel, R., Chisholm, M., and Hagget, P., eds., Processes in physical and human geography: London, Heinemann, p. 69-90.

Knightes, C.D., 2008, Development and test application of a screening-level mercury fate model and tool for evaluating wildlife exposure risk for surface waters with mercurycontaminated sediments (SERAFM): Environmental Modelling and Software, v. 23, no. 4, p. 495-510.

Knightes, C.D., and Ambrose, R.B., Jr., 2007, Evaluating regional predictive capacity of a process-based mercury exposure model, regional-mercury cycling model, applied to 91 Vermont and New Hampshire lakes and ponds, USA: Environmental Toxicology and Chemistry, v. 26, no. 4, p. $807-815$.

Krabbenhoft, D.P., Benoit, J.M., Babiarz, C.L., Hurley, J.P., and Andren, A.W., 1995, Mercury cycling in the Allequash Creek Watershed, northern Wisconsin: Water, Air, and Soil Pollution, v. 80, p. 425-433.

LaPoint, S.D., Curran, R.P., Halasz, S.S., Barge, J.W., Spada, D.M., and Karasin, L.N., 2004, Wetlands effects database and GIS for the Adirondack Park: Ray Brook, N.Y., New York State Adirondack Park Agency, 26 p.

McCuen, R.H., Knight, Z., and Cutter, A.G., 2006, Evaluation of the Nash-Sutcliffe efficiency index: Journal of Hydrologic Engineering, v. 11, no. 6, p. 597-602.

Moore, R.D., and Thompson, J.C., 1996, Are water table variations in a shallow forest soil consistent with the TOPMODEL concept?: Water Resources Research, v. 32, no.3, p. 663-669.

Munthe, John, Bodaly, R.A., Branfireun, B.A., Driscoll, C.T., Gilmour, C.C., Harris, Reed, Horvat, Milena, Lucotte, Marc, and Malm, Olaf, 2007, Recovery of mercurycontaminated fisheries: Ambio, v. 36, no. 1, p. 33-44.

Murdoch, P.S., Peters, N.E., and Newton, R.M., 1987, Hydrologic analysis of two headwater lake basins of differing lake $\mathrm{pH}$ in the west-central Adirondack Mountains of New York: U.S. Geological Survey Water-Resources Investigations Report 84-4313, 49 p.

Nash, J.E., and Sutcliffe, J.V., 1970, River flow forecasting through conceptual models part I-A discussion of principles: Journal of Hydrology, v. 10, no. 3, p. 282-290.

National Atmospheric Deposition Program, 2009, Daily data for site-NY20 (Huntington wildlife): National Atmospheric Deposition Program (NRSP-3), National Trends Network, accessed December 16, 2009, at http:// nadp.sws.uiuc.edu/nadpdata/dailyRequest.asp?site $=\mathrm{NY} 20$. 
National Climatic Data Center, 2002, Climatography of the United States, No. 20-Monthly station climate summaries, 1971-2000: Ashville, N.C., National Oceanic and Atmospheric Administration, National Climatic Data Center, accessed August 19, 2011, at http://www.ncdc.noaa. gov/oa/documentlibrary/pdf/eis/clim20eis.pdf.

Natural Resources Conservation Service, 2009, Soil survey geographic (SSURGO) database for Essex and Hamilton Counties, New York, accessed April 28, 2009, at http:// soildatamart.nrcs.usda.gov.

New York State Adirondack Park Agency, 2000, Adirondack Park Freshwater Wetlands: Ray Brook, N.Y., New York State Adirondack Park Agency, map scale 1:24,000.

Page, T., Beven, K.J., Freer, Jim, and Neal, Colin, 2007, Modelling the chloride signal at Plynlimon, Wales, using a modified dynamic TOPMODEL incorporating conservative chemical mixing (with uncertainty): Hydrological Processes, v. 21, no.3, p. 292-307.

Robson, Alice, Beven, K.J., and Neal, Colin, 1992, Towards identifying sources of subsurface flow-A comparison of components identified by a physically based runoff model and those determined by chemical mixing techniques: Hydrological Processes, v. 6, no. 2, p. 199-214.

Schelker, J., Burns, D.A., Weiler, M., and Laudon, H., 2011, Hydrological mobilization of mercury and dissolved organic carbon in a snow-dominated, forested watershedConceptualization and modeling: Journal of Geophysical Research, v. 116, G01002, 17 p.

Seibert, Jan, Bishop, K.H., and Nyberg, Lars, 1997, A test of TOPMODEL's ability to predict spatially distributed groundwater levels: Hydrological Processes, v. 11, no. 9, p. 1131-1144.

Seibert, Jan, and McDonnell, J.J., 2002, On the dialog between experimentalist and modeler in catchment hydrology-Use of soft data for multicriteria model calibration: Water Resources Research, v. 38, no. 11, p. 23-1 through 23-14.

Selin, N.E., 2009, Global biogeochemical cycling of mercury-A review: Annual Review of Environment and Resources, v. 34, p. 43-63.

Spear, R.C., and Hornberger, G.M., 1980, Eutrophication in Peel Inlet-II, Identification of critical uncertainties via generalized sensitivity analysis: Water Research, v. 14, p. $43-49$.
U.S. Army Corps of Engineers, 1998, Engineering and design — Runoff from snowmelt: U.S. Army Corps of Engineers Engineering Manual 1110-2-1406, 138 p., accessed August 19, 2011, at http://publications.usace.army. mil/publications/eng-manuals/em1110-2-1406/toc.htm.

U.S. Environmental Protection Agency, 2009, The national listing of fish advisories, 2008, accessed August 19, 2011, at http://water.epa.gov/scitech/swguidance/fishshellfish/ fishadvisories/index.cfm.

U.S. Geological Survey, 2008, National Hydrography Dataset, 1:24,000 digital vector coverage, accessed August 19, 2011, at http://nhd.usgs.gov/index.html.

U.S. Geological Survey, 2010, New York annual water-data report, 2009, Volume 1-Eastern New York excluding Long Island, accessed August 19, 2011, at http://ny.water.usgs. gov/pubs/wdr/wdrny091/troy.listing09.pdf.

U.S. Geological Survey, 2011, New York annual water-data report, 2010, Volume 1-Eastern New York excluding Long Island, accessed August 19, 2011, at http://ny.water.usgs. gov/pubs/wdr/wdrny101/troy.listing10.pdf.

Williamson, T.N., Odom, K.R., Newson, J.K., Downs, A.C., Nelson Jr., H.L., Cinotto, P.J., and Ayers, M.A., 2009, The Water Availability Tool for Environmental Resources (WATER) - A water-budget modeling approach for managing water-supply resources in Kentucky_Phase I-Data processing, model development, and application to non-karst areas: U.S. Geological Survey Scientific Investigations Report 2009-5248, 34 p.

Wolock, D.M., 1993, Simulating the variable-source-area concept of streamflow generation with the watershed model TOPMODEL: U.S. Geological Survey Water-Resources Investigations Report 93-4124, $33 \mathrm{p}$.

Wolock, D.M., Hornberger, G.M., Beven, K.J., and Campbell, W.G., 1989, The relationship of catchment topography and soil hydraulic characteristics to lake alkalinity in the northeastern United States: Water Resources Research, v. 25 no. 5 , p. $829-837$.

Wolock, D.M., and Price, C.V., 1994, Effects of digital elevation model map scale and data resolution on a topography-based watershed model: Water Resources Research, v. 30, no. 11, p 3041-3052. 
This page has been left blank intentionally. 
This page has been left blank intentionally. 
Prepared by the Pembroke Publishing Service Center

For additional information write to:

New York Water Science Center

U.S. Geological Survey

425 Jordan Road

Troy, NY 12180

Information requests:

(518) 285-5602

or visit our Web site at: http://ny.water.usgs.gov 


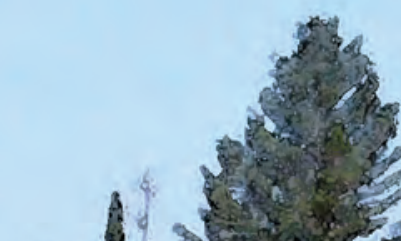

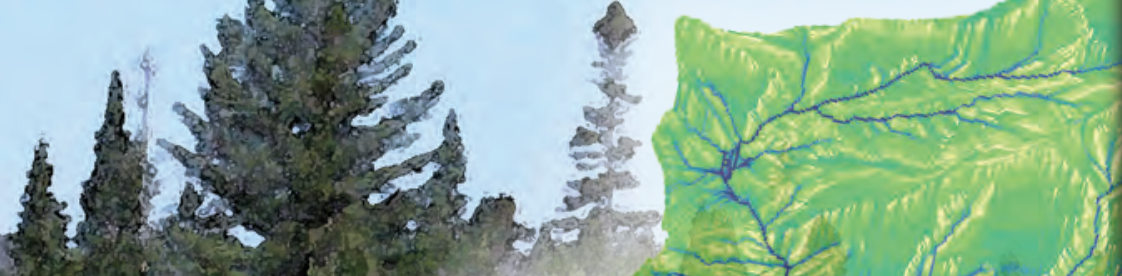

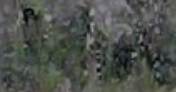

xe

(5)

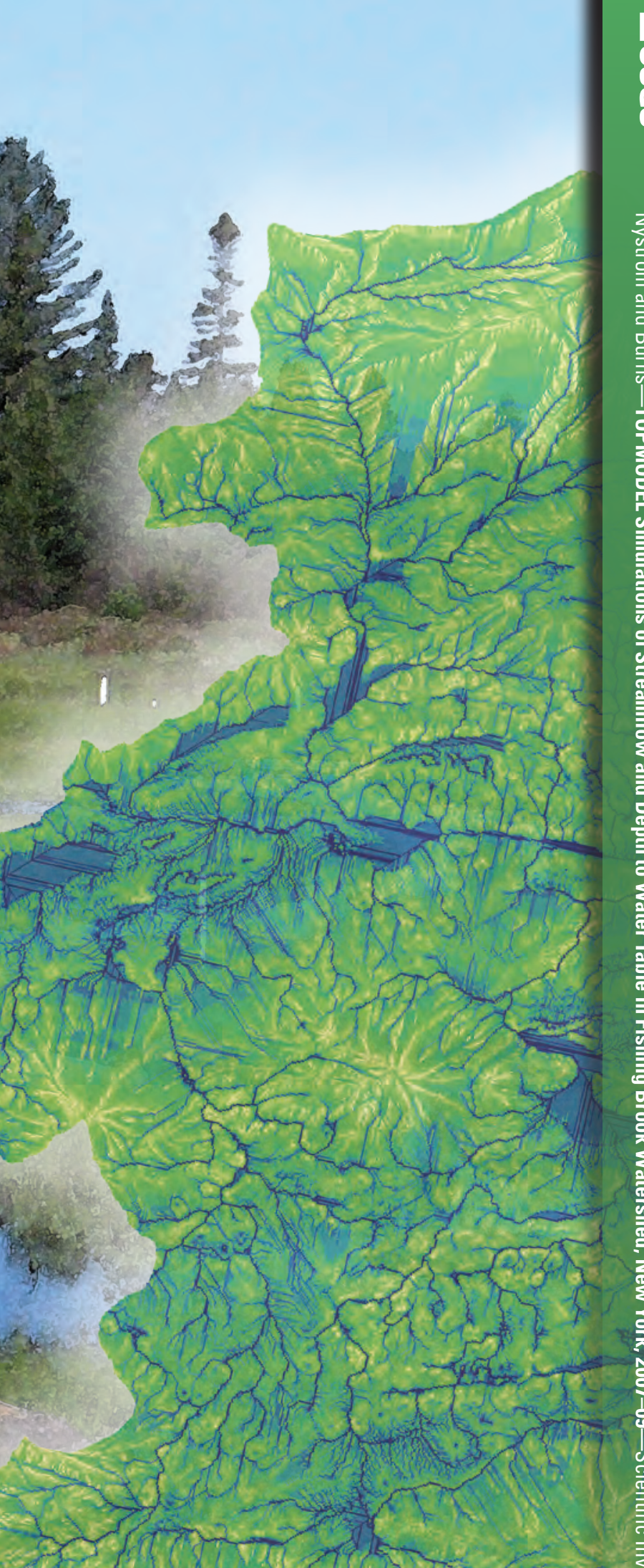
is $x+3 x+2$

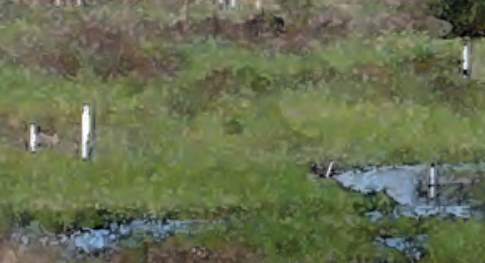

singen
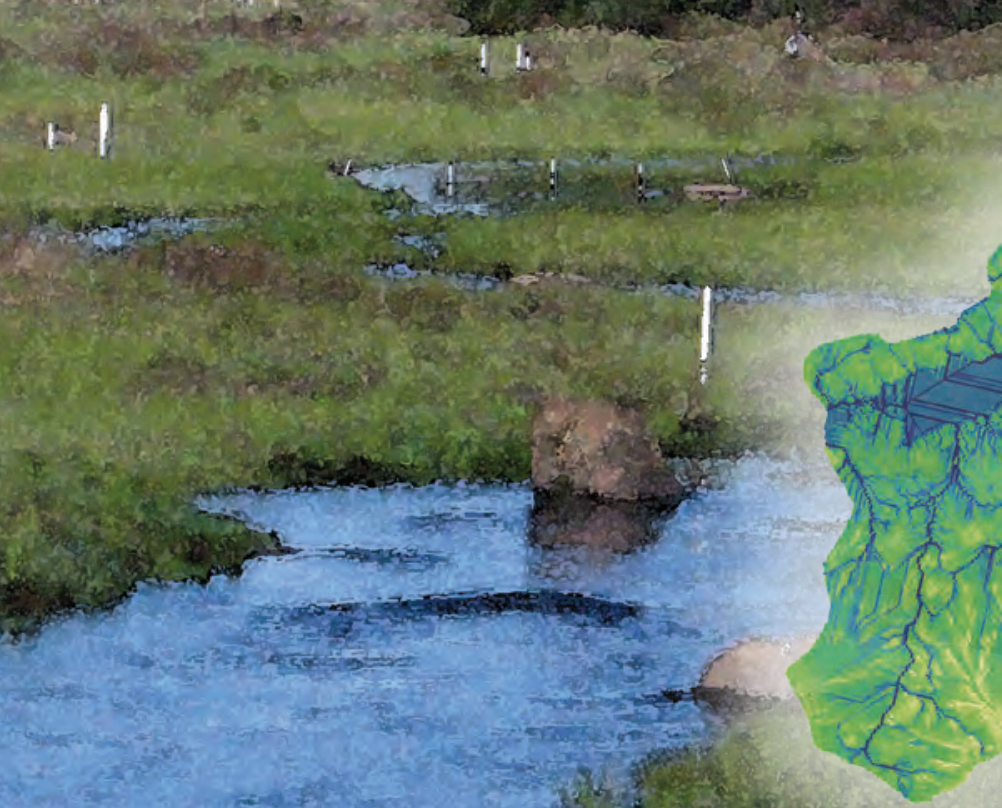

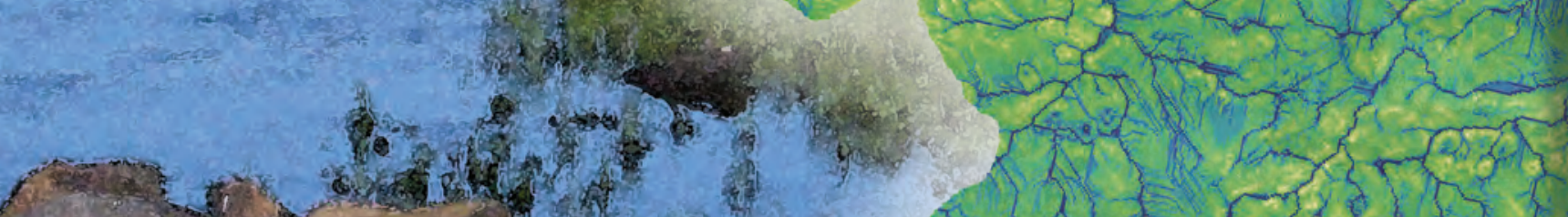

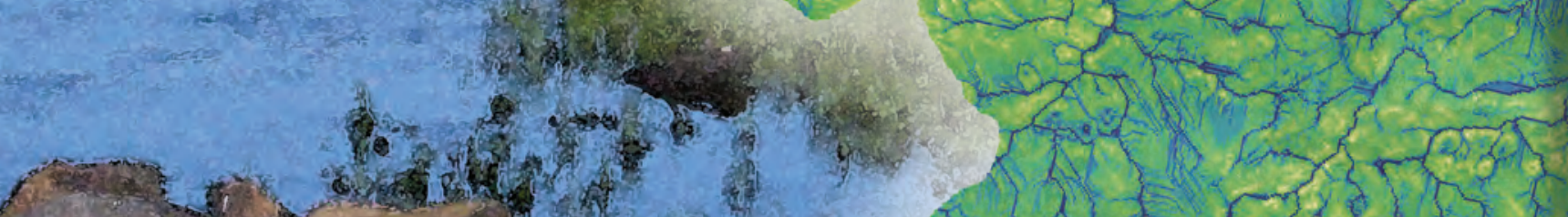

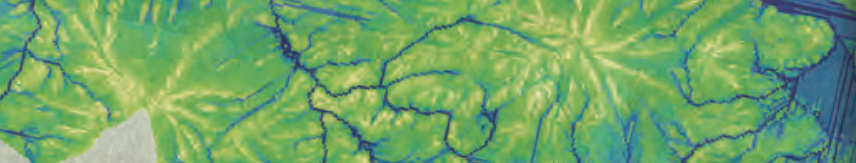

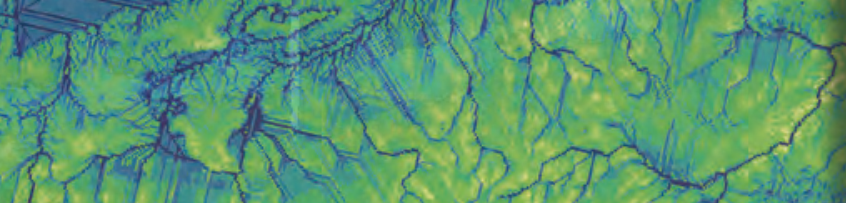

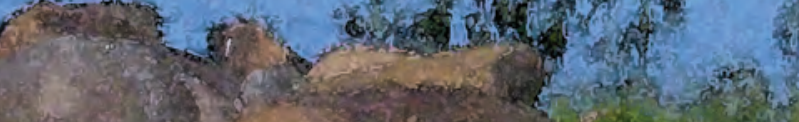
a. 10.5

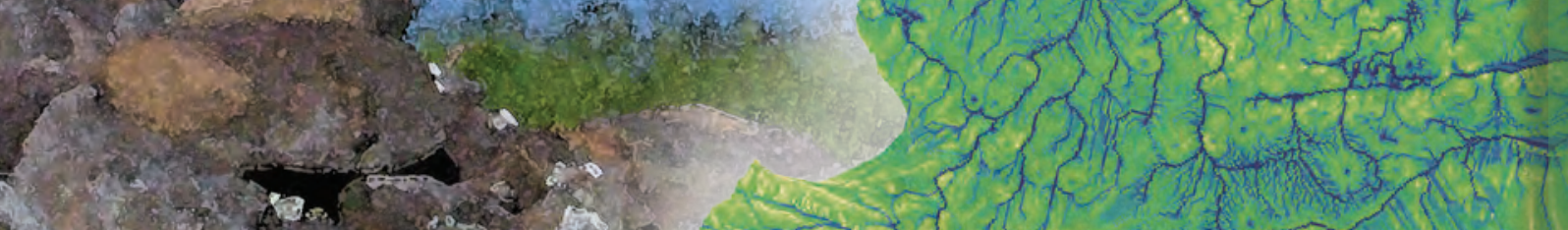

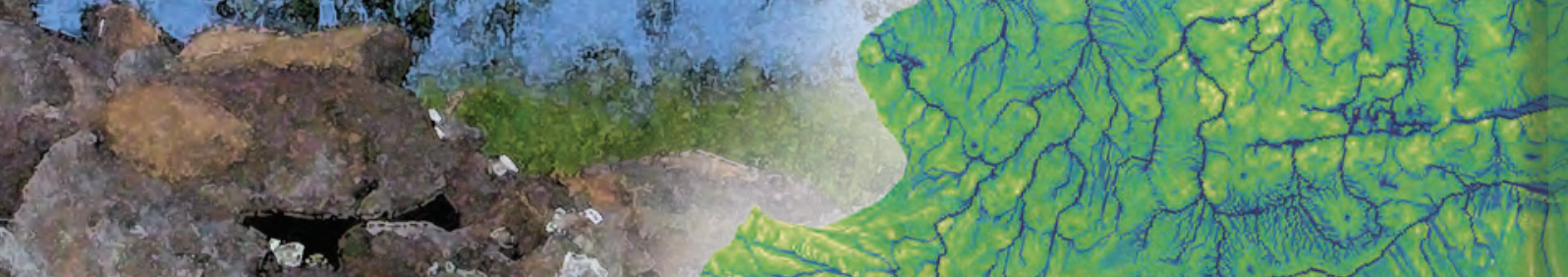

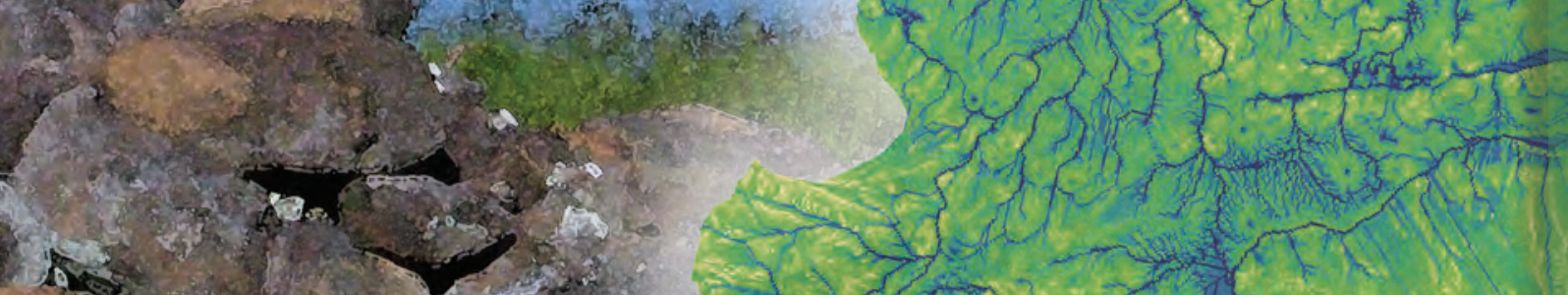

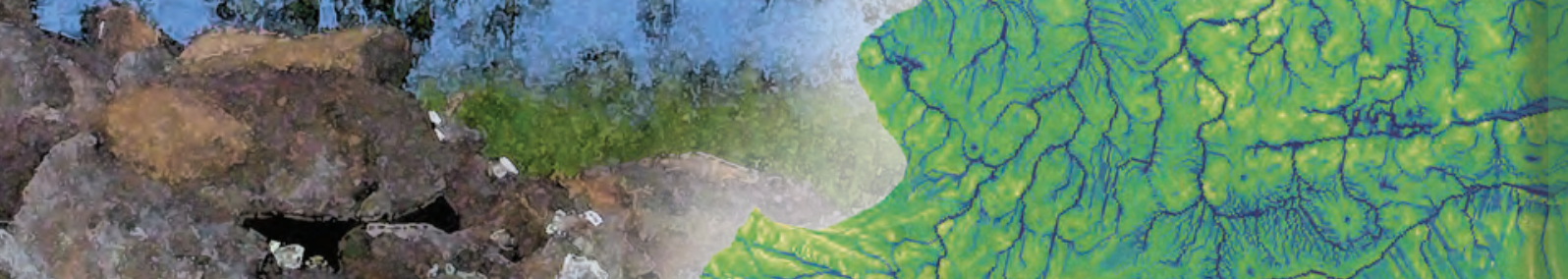
3. 16
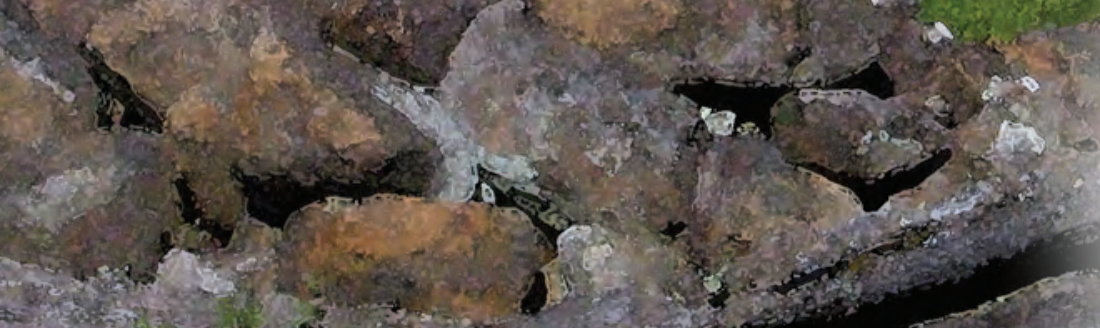

$3^{2} x^{2}$

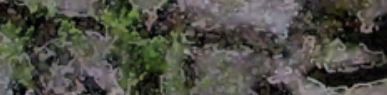

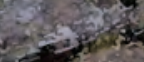

잘

Waris

(6)

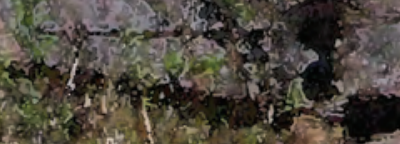

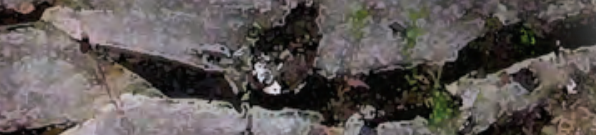

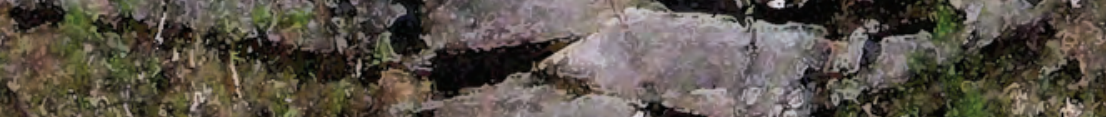

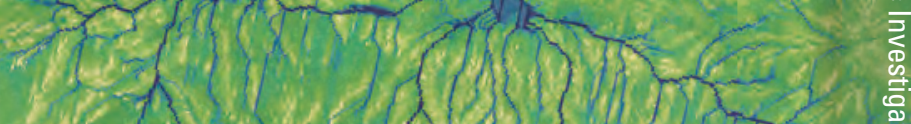

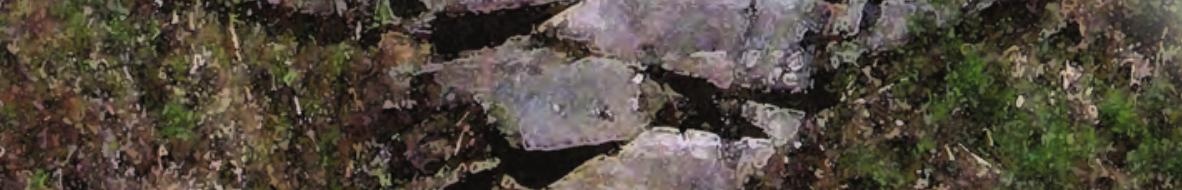
12 (1) 